\title{
SOBRE ARQUITECTURA ART-NOUVEAU
}

\author{
$\mathbf{P} \mathbf{O} \mathbf{R}$ \\ FRA NCISCO DE LA M A Z A \\ A Justino Fernández.
}

\section{Antecedentes}

I A Naturaleza -en el sentido físico del mundo que nos rodeaL estuvo muy poco representada en el Arte Clásico. La arquitectura griega fue, además de arte supremo, natemática pura; la escultura fue esencial y amorosamente humana; la pintura parece que tuvo más relación con la Naturaleza —aquellas legendarias uvas de Apeles, tan realistas, que los pájaros iban a picotearlas o la pintura y los mosaicos romanos- pero, en general, el Arte Clásico y sus derivados, el Renacimiento y el Neoclásico, fueron preponderantemente intelectuales $\mathrm{y}$ humanistas y, por ello, alejados de la Naturaleza.

La línea recta, que no es "natural", que no existe en la Naturaleza -salvo por accidente en los cristales- es una abstracción mental; la proporción, la simetria y el orden, que son también construcciones mentales, fueron las bases de lo Clásico. La razón fue su guia principal y la conciencia vigilante, sin intromisión alguna de la subconciencia, fue su directriz inapelable. "La razón humana - decía San Agustín- es una fuerza que conduce a la unidad." Esta frase lapidaria, escrita precisamente en su libro $D_{\mathfrak{c}}$ Ordine, define al clasicismo de manera rotunda. Hoy diríamos, más humildes y en tono menos apodíctico, que la razón "comprende" a la unidad, pero también se deja conducir por otros caminos. 
Mas la unidad no es el todo, como pensaron los clásicos. Lo uno presupone lo inmóvil y por eso los griegos consideraron al movimiento como algo imperfecto; la movilidad existía muy a su pesar. La negación del movimiento en los labios de los sofistas no fue un juego pueril, sino una actitud desesperada para ponerse de acuerdo consigo mismos.

De aquí lo estático del arte griego, de la admirable "arquitectura que pesa", del triunfo de lo tectónico. (Esto en cuanto a las ideas, no en cuanto a los sentimientos, los más amplios, coherentes y libres -dentro de su férrea pero gustosamente admitida politica estatal- que han existido en la historia precristiana. Por ello repito que me refiero a la inmovilidad cósmica, no a la anímica, en el sentido que da Platón en el Fedro al "movimiento continuo inmortal del alma" ni al "primer móvil" aristotélico. Lo clásico, como dice Justino Fernández, es el "absolutismo ontológico".) Lo vario, en cambio, presupone lo móvil, la polaridad, el descentramiento, la asimetría, como resultado de la complejidad natural y humana puesta en acción.

El clásico persigue al pensamiento y de él toma su fuerza y sus temas. La Naturaleza casi llega a serle un estorbo. En cambio en las formas no clásicas - salvo el mundo árabe, por razones religiosas-, triunfa la Naturaleza. La línea curva, que es "natural" y no una abstracción, se erige en dominadora de todo dibujo; la estricta proporción pierde sentido; la razón se doblega ante la intuición y muchas veces es la irracionalidad - no la sin razón, que es diferente - la guia de esas formas. En lo no clásico - lo oriental, lo gótico, lo barroco, lo modernosurgen productos cuya meta no es la "unidad" o la "perfección", sino la compleja expresión del sér del hombre, partícipe y no distinto o adversario de la Naturaleza; surge lo dinámico $\mathrm{y}$, como dice Eugenio D'Ors, lo "panteísta", disparado hacia diversas metas que no pretenden la continua unidad metafísica de los clásicos - a pesar de su innegable hilozoísmo pero contra el cual luchaban- sino la discontinua variación en movilidad perpetua y admitida. Lo no clásico va más allá de leyes o normas académicas, se abre al ancho campo de lo intuitivo $y$ desbordado, de lo subconsciente y lo sentimental, del desordenado y aun anárquico modo de ser de la mente humana.

E1 clásico no encontró en la Naturaleza la "perfección" que buscaba st1 espiritu, su inconmovible vóos y se refugió en las ideas platónicas, en las esencias aristotélicas, en las entelequias. EI no clásico encuentra en sí mismo y en la Naturaleza, no lo perfecto, que no lo tiene ni le interesa, sino lo vital. "¿Dónde aprendí yo la escultura?" se pregunta Rodin, y dice: "en los bosques, mirando los árboles; en los caminos, 
observando la construcción de las nubes; en los talleres estudiando el modelo; en todas partes, excepto en las escuelas; lo que aprendí de la $\mathrm{Na-}$ turaleza he tratado de ponerlo en mis obras". 1 Esto no lo hubiera afirmado jamás un Praxiteles. Y le decía una vez a Rilke: "Si hubiese tenido que elegir entre el estudio de las plantas o de los animales y los hombres, creo que hubiera preferido la botánica a la anatomía..." y el mismo Rilke nos cuenta que "se apostaba para pintar frente al paisaje como un cazador, limitándose primero a contemplar; de esa maneră tomaba parte en el paisaje, se le incorporaba, llegaba a ser él mismo, paisaje". 2

Ia columna clásica es una cuidadosa elaboración de medidas y proporciones para servir al apoyo a que fue destinada y que debe representar en todo su exterior; por ello es recta y desnuda. La columna gótica o la barroca $\longrightarrow$ la popular- son desmesuradas y torcidas; no tienen cánones matemáticos para su altura o su diámetro - - in que por ello caigan en lo absurdo- porque saben, sencillamente, que pueden ser apoyos sin tiranías matemáticas y sin necesidad de demostrarlo por su verticalidad visual.

Los arquitectos del Partenón se preocuparon de que las columnas fueran exquisitamente proporcionadas a la altura, a lo largo y a lo alto del templo de Palas Atenea, pero Bernini no midió ni lo ancho ni lo alto de la nave de San Pedro para construir las columnas salomónicas de su baldaquino bajo la rotunda cúpula renacentista, ni le importó torcerlas frente a las rectas y severas pilastras que sostienen los arcos de la basílica.

$\mathrm{Y}$ es que todo un mundo de sentimientos religiosos, filosóficos y morales separa lo clásico de lo no clásico. Por lo pronto me interesa señalar ese elemento formal que los separa de manera radical: su alejamiento o su cercanía de la Naturaleza; el desdén o la entrega a la Naturaleza; el sentirse desligados o, al contrario, participes de la Naturaleza.

Los grandes pasos, en este estricto sentido, de lo grecorromano al siglo $\mathrm{xx}$, pueden esquematizarse en unas líneas generales que tal vez sean artificiosas, pero no erróneas, en cuanto al "naturalismo" formal desdeñado o buscado por las épocas. Sería así:

1 Las Catedrales de Francia. Editorial "Ateneo", Buenos Aires, p. 26.

2 Cartas a Rodin. Ediciones "Archipiélago", Buenos Aires, pp. 105 y 106. 


\section{Grecia-Roma $\rightarrow$ Renacimiento $\rightarrow$ Neoclásico contra \\ Gótico $\rightarrow$ Barroco $\rightarrow$ Art-Nouveau}

La directriz de la primera relación sería la línea recta; la Naturaleza está casi ausente; la de la segunda sería la línea curva; la Naturaleza está siempre presente. $\mathrm{Y}$ las dos relaciones unidas por unos misteriosos hilos sustentantes.

Viene a cuento esta "greguería" de Ramón Gómez de la Serna: "Si fuésemos geometría, si pudiésemos cristalizar en cuerpos geométricos, estaría bien que amásemos lo rectilíneo, lo cuadrangular, lo rígidamente poliédrico; pero somos humo, delicuescencia, blandos, perezosos, languidescentes, agónicos, y entonces tenemos que propender a lo sinuoso, a lo que reúne el Nouveau Style... hay más voluptuosidad humana reservada dentro de esa arquitectura de las casas... los muebles concebidos en ese estilo son como un renacimiento de la intimidad y del amor ... la aplicación a ese estilo quiere decir que nos ponemos a vivir otra vez crédula y simpáticamente... los que vivían dentro de esas casas querían vivir dentro de un pensil y sentir que daban al exterior de un modo blando y macerado, como desperezándose en la fachada, como abrazando al aire con la curvatura de sus brazos de seres modernistas ... ${ }^{3}$

\section{El Modernismo y el Art-Nouveau}

Preciso es, para hablar del Arte Modernista, recordar estos antecedentes, ya que ha sido el último movimiento o estilo artístico - no hablo del Arte contemporáneo- que se entregó con alma, vida y pasión a la Naturaleza $y$ vio en ella, con sus formas vegetales, animales $y$ hasta geolögicas, el tema $y$ fin de su actuación artística. En este ensayo me circunscribo al movimiento llamado Art-Nouveau -y sólo a la arquitectura- que, si bien tuvo una vida muy escasa, de unos veinticinco años, la significación que dió al arte europeo y americano fue de mucha trascendencia. El Art-Nouveau es la reacción contra el Academismo y el Romanticismo y la preparación para el Arte Contemporáneo. Nada menos. Fecundo puente que liga el siglo pasado con el presente, el Barroco con el Arte Moderno. Liguida una época y abre otra.

Cada nación conoce este "nuevo" estilo fin-y-principio-de-siglo con palabras de su idioma: es el Art-Nouveau en Bélgica y Francia; el

3 Lo Cursi y otros ensayos. Editorial Sudamericana. Buenos Aires. 1943, pp. 24 y 25. 
Modern Style en Inglaterra; el Jugend Still en Alemania. En España se quedó con el apellido de su más grande representante: Gaudí. Los americanos, es decir, los hispanoamericanos, lo llamamos siempre Art-Nouveau porque de Francia nos vino y nada debemos, en este aspecto, a Inglaterra, España o Alemania. El caso, tan importante para México del italiano Adamo Boari, se resuelve, en última instancia, también en Francia, pues Boari, en sus obras Art-Nouveau, fue un típico afrancesado.

El origen del Art-Nouveau ha sido muy discutido. Los ingleses dicen que a ellos se debe; los franceses lo reclaman; los belgas comprueban que ellos fueron los iniciadores; los alemanes aventuran teorías al respecto y hasta los catalanes quieren exhibir fechas anteriores a las obras $\mathrm{Art}$ Nouveau del resto de Europa.

Los ingleses presentan el "prerrafaelismo" de John Ruskin como esteta y crítico y a Holman Hunt, Dante Gabriel Rossetti, Burne Jones y otros como pintores $y$, sobre todo, la obra de William Morris como decorador y constructor. "Los prerrafaelistas -escribe uno de ellostentamos volver a los días del pasado anteriores a Rafael sólo en este punto: el de querer representar las cosas tales como son o como suponemos que debian haber sido, abandonando toda convención y regla en la pintura." " Es interesante la rectificación del "como son" las cosas con el "suponemos que debían de haber sido", porque, en efecto, la desleída pintura prerrafaelista es sólo una suposición, y muy débil, de la realidad. Sin embargo, dos cosas tienen alto valor en este movimiento: su deseo de liberarse de lo académico, de innovar, y su amor por la Naturaleza.

Roechlin, en su libro Art français moderne, reconoce que "el renacimiento de las artes decorativas marcha del brazo con la pintura, pero no fue en Francia donde se tocó el resultado de las primieras tentativas; Alemania, desde luego, no contó en nada; fue Inglaterra, con Morris, la que se llevó los honores". En cuanto a decoración no es dudable, pero en cuanto a arquitectura son los belgas los iniciadores del ArtNouveau con un hombre, una fecha y una casa.

4 En Historia del Arte, de José Pijoan, Barcelona, Editorial Salvat, tomo III, p. 511. 


\section{El arquitecto Victor Horta}

El hombre es Víctor Horta; la fecha es 1893 y la casa es la Tassel, de Bruselas. El arquitecto francés Héctor Guimard conoció a Horta y tuvo una entrevista con él. Le preguntó cuáles eran sus principios arquitectónicos y decorativos y el artista belga le contestó con la frase, que se haría famosa en esos años, de que "il avait complètement banni la feuille et la fleur et qu'il s'en tenait à la tige". Este abandono de la hoja y de la flor y de sólo atenerse al tallo extrañó al principio al joven Guimard, a quien le pareció raro que escogiera "los elementos de la Naturaleza menos decorativos", pero después, habiendo visitado la casa Tassel y reflexionando despacio, "le pareció todo excelente". "Ya veremos el porqué de esa preferencia hortiana al tallo y el apoderamiento posterior de la hoja y la flor.

Emile Bayard, que quiere a toda costa originar el Art-Nouveau en Francia, tiene que reconocer, a regañadientes, la prioridad belga de Víctor Horta, "quien parece haber señalado el punto de partida de un arte verdaderamente nuevo en el conjunto de sus manifestacinnes: arquitectura, mueble, decoración; todo era inédito". Y no contento con el huidizo "parece", se contradice y añade para afrancesar a Horta: "en suma esto era volver a los principios del arte ojival que, para la construcción de sus bóvedas, de sus columnas, se atuvo al tallo". "Mas la afirmación es gratuita y precipitada; más le debe, en todo caso al Barroco que aI Gótico.

Más lealmente, Cirici Pellicer y el eminente investigador contemporáneo Sigfried Giedion, aceptan la paternidad de Horta en el ArtNouveou. Dice el primero: "La creación de la arquitectura moderna pertenece a Bélgica, país que con Maeterlinck y Verhaeren dió carácter al modernismo literario. Allí V'́ctor Horta estableció en 1893, con la casa Tassel, las normas fundamentales de un funcionalismo que combina la simplicidad de los volúmenes con la caprichosa decoración curvilineal." ?

Y Giedion: "La casa de Horta señaló un cambio en la evolución de la casa particular; desde ese momento fueron aplicados nuevos prin-

5 L'Architecture, journal hebdomadaire de la Société Central des Architects français. Num. 15, 15 avtil, 1899, p. 128.

6 El Estilo Moderno. París, Garnier Hermanos, s. f., p. 104.

7 En Historia de los Estilos Artísticos, de K. D. Hartmann. Colección Labor. Quinta edición, p. 353. 
cipios al problema de la habitación... esta casa despertó de golpe a la arquitectura continental de su letargo." $Y$ añade: "La casa de Horta fue inmediatamente famosa en todos los ambientes europeos que se interesaban en la resurrección de una arquitectura vital; fue admirada, sobre todo, por la perfecta adaptación al gusto del propietario y su independencia de otras trazas de estilos históricos." 8

Sólo el catalanísimo Juan Eduardo Cirlot nos dice que pacientemente espera "un estudio más minucioso y una veracidad fechada más exacta que la que otorga a Víctor Horta el papel de iniciador en Europa de la arquitectura modernista". ${ }^{\circ}$

Víctor Horta nació en 1861 ; fue discípulo de Alfonso Balat, arquitecto del Rey de los Belgas Leopoldo II. A Balat reconoció Horta, con toda nobleza, como su principal inspirador por sus obras de la residencia de Laecken en 1879. El rey recompensó al artista, en 1913, con el título de Barón de Horta.

Después de la casa Tassel hizo el Palacio de Bellas Artes de Bruselas y muchas otras obras. Junto con él hay que citar a Paul Hankar, quien fue el primero en resolver arquitectónicamente y en plan artístico, la construcción de una gran tienda en los Magasins de la Maison Claessen, y a Henri Vandevelde como pintor, dibujante y decorador.

La casa Tassel, descrita y elogiada por Giedion (allí está la respuesta para el señor Cirlot), es en su exterior aun muy sobria. La puerta y la ventana del entresuelo son sencillas, adinteladas y con rejas rectilineas; en el primer piso comienzan las innovaciones, cuando la doble ventana central se hace convexa y la barandilla del balcón ya se atiene al tallo en sus curvados herrajes. Es en el interior donde está, totalmente plasmado, el Art-Nouveau, de tal manera que nada le añadieron de esencial sus seguidores. La escalera se mueve $y$ ondula como una serpienté insólita y graciosa; la columna de hierro que sostiene la armadura donde se apoya la arista de las bóvedas del primer piso es como un tronco de árbol del cual salen tallos curvilineos que recorren la ar-

8 Spazio, Tempo ed Architettura. Hoepli Editore. Milano, 1954, pp. 288 y 289.

9 El Arte de Gaudi. E'diciones Omega. Barcelona, 1950, p. 19. 
madura en consonancia con el barandal de la escalera y los dibujos, en mosaico y pintura, del piso y del muro. El vestíbulo sostiene, por medio de ligeras columnas de hierro, unidas por arcos del mismo metal, un luminoso plafond" de vidrio que es una verdadera cúpula.

“¿Qué conserva ahora de importancia la casa Tassel ?" - -se pregunta Giedion- y se responde: "No tanto la perfecta sintonía con su propietario, ni aun que sea la primera aparición del Art-Nouveau; es, más que eso, su planta flexible, el uso de los nuevos materiales, la libre disposición de los ambientes en sus diversos niveles y la independencia de éstos con la planta; es uno de los primeros ejemplos europeos de los que Le Corbusier llamará más tarde el plan libre." 10

¿Por qué fue en Bélgica donde empezó y se desarrolló el Modernismo? Porque a fin del siglo fue esa pequeña y maravillosa nación la que estaba más industrializada de Europa y, por eso, era ingente en ella el resolver el problema arquitectónico de su momento, que no resolvía el Academismo imperante. Además, la presencia de grandes artistas, excomulgados en Paris, contribuyó en forma importante. En Bruselas expusieron y fueron comprendidos Seurat, Cézanne y Van Gogin; alli Rodin reivindicó varias de sus obras menospreciadas en Francia y fue en Bruselas donde los primeros conciertos de Debussy tuvieron éxito. "Estas exposiciones, conferencias, conciertos, representaron el primer ataque sistemático a un gusto general que, por decenas de años había estado corrompido por un arte que excluía todo contacto con la vida", dice Giedion, exagerando, ya que, con esta frase contundente cumple con aquello de Flaubert: "Todo estilo nuevo odia al que le precede."

\section{La obra de Antonio Gaudi}

Volveremos sobre el Art-Nouveau en Francia, pero antes es necesario hablar de una personalidad extraordinaria en este aspecto: Antonio Gaudi, de Barcelona. Ya he dicho que uno de sus biógrafos, Cirlot, intenta colocar a Gaudi como creador del Art-Nouveau, para lo cual grita triunfante la fecha de 1878 con la casa Vicens, de Barcelona, "que creó una verdadera realización del estilo que se iba fraguando". "11 Pero

10 Giedion, op. cit., p. 22.

11 Cirlot, op. cit., p. 294. 
viendo la casa Vicens sólo comprobamos el nacionalismo de Cirlot. Es una obra "neomudéjar", por llamarla de algún modo, sin que nada la caracterice todavía como el verdadero Art-Nouveau, salvo la verja de entrada (que parece posterior), concebida con unas feroces hojas de palma en una hilera de ruedas que ya presagian la agresividad de Gaudi.

En 1885 comienza la casa Güell, en la que hay novedad y evasión de las viejas formas, pero no lo que llamamos el Art-Nouveau. En donde ya aparece éste es en las casas Batlló, Milá y Miralles, en el parque Güell y en la iglesia de la Sagrada Familia. En la casa Batlló el copete ondula y se cubre de piedras en forma de escamas; los balcones llevan barandas en forma de antifaces y! las jambas y dinteles se curvan. En la casa Miralles los muros son como piel de elefante y en la Milá, que ondula toda ella horizontalmente como una ola que va a reventar sobre la calle, las chimeneas son máscaras y cráneos perforados y los balcones llevan barandillas con festones caidos y arrugados, como los ramos que recogen los criados de los floreros después de una fiesta. En el parque Güell las columnas y pilastras son inclinadas, junto con los muros, de una manera inquietante y ... molesta; los pórticos se llenan de amenazadoras estalactitas que hostilizan con sus agudas puntas al visitante; las bancas ondulan como víboras en celo y por doquiera se ven los "árboles de piedra", es decir, terribles bloques de piedra hirsuta en cuyas cimas van arbustos. Pero ¿a qué vienen árboles de piedra si los de madera, los naturales, son tan hermosos? Esto, más que Art-Nouveau, es "gau-. dinismo" puro.

Si Horta sólo quiso el tallo, Gaudí tomó toda la Naturaleza. Ninguno de los dos usó la flor, pero Horta se mantuvo en el equilibrio del tronco y de sus ramas; Gaudi recurrió a la geología y a la paleontología; a los caparazones de los quelonios y a los vientres de los proboscidios.

\section{Los insultos necesarios}

Todo lo nuevo debe sufrir desprecios de los misoneistas, aun a veces de hombres de gran talento. En 1918 Antonio Prast (no es el caso del talento; eso lo digo por Dali, que viene después) en su libro Arte Barroco de Madrid (que, aparte de los magnificos dibujos de Bustos de la obra de Pedro Ribera, es sólo un gran folleto de propaganda para el "neobarroquismo monumental que se plasmó, desgraciadamente, en Madrid copiando a Ribera) dice: "Después del Imperio francés, todas las naciones, hasta hoy, han dado muestras, con deseo ferviente, de llegar 
a concretar un estilo característico y, de todas ellas, Alemania y Francia son las que con más valentía han luchado. Francia con su modernismo no logró más que triunfos pasajeros; la avidez de novedad acogió sus primeros trabajos con entusiasmo, pero aquellos trabajos sin fundamento vinieron al suelo con estrépito; en España tuvo también terreno abonado aquel germen, pero no prosperó más que en el elemento vulgar, Ilamémosle cursi. Alemania fue también inoculada de aquel virus ponzoñoso $y$ hoy todavia, aunque en pequeña escala, podemos ver manifestaçiones de aquel género en muchas industrias artísticas ... desde los tiempos primitivos hasta el siglo xvirI inclusive, el arte era demostración justa de la intelectualidad de la época, pero desde entonces a hoy se sobrepasa a la realidad en formas descompuestas; se enmienda a la Naturaleza constantemente, sin poder apreciar si es por el deseo de mejorarla o de buscar a ciegas formulismos que hagan impresión pasajera sin tener en cuenta que esas obras quedarán y serán el baldón de ignominia de nuestro siglo." 12

Salvador Dali, el genial y dulce Dalí, que se cree un monstruo y es un arcángel, escribió estos párrafos contradictorios y deliciosos: "Ningún esfuerzo colectivo ha llegado a crear un mundo de sueños tan puro y. tan impresionante como estos edificios Modern Style, los cuales, al margen de la arquitectura, constituyen por sí solos verdaderas realizaciones de sueños solidificados en los que el más violento y cruel automatismo traduce dolorosamente el odio a la realidad y la necesidad de refugiarse en un mundo ideal." Dalí creyó hablar con este trozo de todo el Art-Nouveau, pero se equivocó. Sólo a Gaudi le es aplicable. El verdadero Art-Nouveau no está "al margen de la arquitectura", como se ha visto, ni es cruel, ni hay odio. $Y$ prosigue genialmente desbarrando: "El Modern Style (los españoles siempre le llaman asi, en inglés, o en francés e inglés, como, según se vio, lo cita Gómez de la Serna) es escultura de todo lo extraescultural: el agua, el humo, las irisaciones de la pre-tuberculosis y de la polución nocturna, la mujer-flor-joyas-nubellamàs-mariposa-espejo. Automatismo ornamental. Estereotipia. Neologismo. Presencia de los elementos oníricos característicos: condensación, desplazamiento, etc. Coprophagie ornamental flagrante..." Bien se ve que Dalí no conoce el verdadero Art-Noveveau. Por eso es falso que diga : "Yo he sido el primero en considerar sin humorismo el Modern Style como el fenómeno más original y extraordinario de la Historia del

12 Arte Barroco de Madrid, Cuaderno N॰ 1, enero de 1918. 
Arte." ${ }^{13} \mathrm{Y}$ conste que él pudo haber sido el crítico por excelencia del Art-Nouveau, pues ha estado muy cerca de él en espíritu y aun en forma.

Menos aún está en lo cierto Pevsner cuando habla de "un estilo debilitado y debilitante pero fascinador, con arquitectura de pelo húmedo petrificado, con su mueble sonambulístico, de flores desmesuradas, que son, en confusión irracional, como el fruto de una alucinación". Y menos aún el torpe e ignaro insulto, en 1920, de Adolf Loos, quien llamó "criminal" al Art-Nouveau.

Añado este trozo de F. Pérez Dolz por estar escrito en un manual de Historia del Arte, o sea en un libro asequible para todos, lo que aumenta su peligrosidad. En el capítulo Ix, titulado "Siglo xIx. Decadentismo", dice que lo que el siglo produjo - salvando a Morris- "fue el horripilante modernismo, última y desdichada derivación de las evoluciones barrocas..." ${ }^{14}$ Sobran comentarios.

\section{La opinión de Reinach}

También en un manual, pero por un hombre inteligente y de la época, Salomón Reinach, se dicen estas palabras de unas conferencias que dictó en 1902 y que luego reunió en el conocido libro titulado Apolo: "En Inglaterra y Bélgica es donde ha aparecido, hace algunos años, un estilo nuevo que, más aún que el metálico, parece destinado a acabar on nuestros días con las imitaciones de la Antigüedad y del Renacimiento. Primero en Inglaterra, bajo la influencia del estético Ruskin, William Morris y otros artistas, secundados por los pintores Burne Jones y Walter Crane, se transformó la decoración interior de las casas, sustituyendo a los modelos convencionales y gastados de los muebles, telas y ornamentos de aplicación con formas expresivas o que, al menos, quieren serlo. Más tarde dos arquitectos, los belgas Horta y Hankar, se atrevieron en 1893 a aplicar principios no menos atrevidos en la decoración, reaccionando con energía contra las imitaciones $y$ rompiendo con la tradición. Un austriaco, Otto Wagner, conoció este movimiento belga y se hizo el iniciador en Viena de una nueva escuela de construcción llamada de Secesión, nombre que basta para indicar su carácter de independencia y hasta de rebeldía. De Viena pasó la herejia a Berlín, Darmstadt y aun a Paris; hasta hoy, sin embargo, el nuevo estilo no ha tenido ocasión

13 Citado por Gómez de la Serna en Lo Cursi.

14 Introducción a la teoría del Arte. Barcelona. Editorial Apolo, tercera edición, p. 214. 
de manifestarse en ningún edificio público (se refiere Reinach a París). Definir este nuevo estilo anglo-austro-belga es casi imposible, pues no tiene credo y busca su camino en direcciones muy diferentes; lo cierto es que existe y que se afirma en la decoración y disposición de construcciones particulares y que su pretensión de ser de su tiempo y de rechazar todo anacronismo, lo relaciona, dejando a un lado las aberraciones individuales, al gran programa de buen gusto y buen sentido trazado hacia 1860 por Viollet-le-Duc." 15

Cierto es que Reinach comete una injusticia al derivar el nuevo estilo en Francia de la escuela de Viena, pues ya sabemos que viene directamente de la fuente belga y parece ignorar las obras de Guimard y Binet en París, que, cuando menos, estaban en construcción. Mas su elogio y su comprensión del Art-Nouveau honran mucho al historiador judio-francés.

\section{Paréntesis con Narciso Tomé}

No puede ignorarse, hablando del Art-Nouveau, a un interesante artista del barroco español del siglo xvirr, poco conocido y menos estudiado, pero, eso sí, con unaj pesada carga de insultos que nadie ha intentado todavía quitársela de encima. Me refiero a Narciso Tomé, autor del Transparente de la Catedral de Toledo, del retablo mayor de la Catedral de León, de la fachada de la Universidad de Valladolid. Anticipo que no tengo la ingenuidad de suponer que haya influído Tomé en los artistas del Art-Nouveau, que ni de lejos lo conocieron, sino que lo hago intervenir y lo recuerdo en este ensaya porque casi doscientos años antes que los modernistas, él había ya plasmado estas formas naturales en sus obras, con un intento de crear un barroco personal (que logró, pese a quienes todavía lo odian) no churrigueresco, huyendo de la poderosa influencia que en Castilla y aun en toda España, había logrado el genio de José Benito Churriguera.

Narciso Tomé no usó nunca la columna salomónica o la pilastra estipite, obligadas en su momento, cuando en 1736 construye el Transparente de Toledo o en 1738 el retablo de León. Sus columnas son de fuste clásico, acanalado, pero cubiertas con unas pieles que se desgarran de repente y dejan asomar las estrias; estas pieles, también de golpe, se convierten en querubines, querubines con hombros y principios de brazos de los que brotan las alas de plumas, plumas, más que de aves, de espuma.

15 Apolo. Historia, de las Artes Plásticas, Madrid, 1930, p. 159. 
El marqués de Lozoya ha llamado a estas columnas "despellejadas", feo pero adecuado nombre. Además, la manera como trata el mármol, como si fuese tela, abriendo huecos de caprichosas curvas chorreando guirnaldas estilizadas o desgarrándolo como si fuese una piel, le dan categoría de antecesor del Art-Nouveau. Si los modernistas de fin de siglo lo hubiesen conocido lo hubieran considerado su maestro lejano.

\section{El Art-Nouveau en Francia}

Como, según he indicado, nuestro Art-Nouveau proviene directamente de Francia, debemos señalarlo con mayor insistencia, recordando el movimiento arquitectónico francés del siglo xIx.

Desde la época de Luis XVI comenzó el clasicismo. Los libros de Laugier, de Blondel, de Milizia y, desde luego, de Winckelmann, eran los textos de los arquitectos anteriores a la Revolución. Estos autores eran clásicos recalcitrantes, conocedores del arte de Roma y del de Grecia en Italia, tan imbuidos en la "pureza" de lo antiguo que Milizia, por ejemplo, se atreve a censurar y hasta casi insultar a Miguel Angel por no ser un fiel esclavo de la escultura antigua y tomarse personales libertades; "el Cristo de la Minerva - decía- es un sayón cargado con la cruz y la Virgen de la Pietá tiene expresión y afectos de lavandera". ${ }^{16}$ iA tales extremos lleva la pasión por lo clásico! (No es este el caso de Winckelmann, apasionado, sí, por la belleza, pero sin que esta pasión le cegara y le impidiera ser un crítico riguroso.)

El clasicismo no se interrumpió con la Revolución y prosiguió con el cesarismo de Bonaparte y los arquitectos siguieron llenando a París y a Francia de monumentos clásicos. Fontaine, que había viajado por Italia seis años (1785-1791), proyectó todos los palacios napoleónidas e intervino en todas las obras "romanas" del Imperio. En 1806 Lepere y Gondoin erigen la columna Vendome, que es un trasunto de la trajana, y los arcos de triunfo son réplicas, más o menos libres, de los arcos romanos, como el del Carrousel, de Fontaine y Percier, y el de L'Etoile, de Raymond y Chalgrin.

Pero desde antes, desde 1757, animaba este espíritu clásico el proyecto y comienzo de la iglesia de la Magdalena, en París, que no se terminó sino hasta la época de Luis XVIII con Vignon. Si de pie ante las ocho grandiosas columnas corintias y su soberbio frontón no nos

16 En M. Menéndez Pelayo. Historia de las Ideas Estéticas en España. Santander, 1947, tomo IIr, p. 538. 
fijamos que en éste se ostenta el relieve de Cristo y la Magdalena en lugar de una Palas Atenea, creeríamos que estábamos ante un templo antiguo. No inútilmente juzgó necesario Vignon poner en el friso estas grandes letras: Domus in voc. S. M. Magdalenae.

Los arquitectos posteriores a Napoleón siguieron los mismos gustos. Ledoux decía: "La belleza es sólo la proporción." Pero hubo un curioso incidente que hizo variar un poco la ciega adoración por lo grecorromano: el conocimiento de Egipto y del Cercano Oriente por las campañas napoleónicas. Cuando el conde Eugenio de Beauharnais se hizo su casa en la rue de Lille, el peristilo resultó un pilono egipcio, sostenido por columnas papiriformes y con un gran relieve del ureus faraónico en el friso. Sin embargo, esta moda pasó pronto. Se volvió a lo clásico y los edificios para bancos, museos, oficinas, escuelas y hasta cuarteles fueron "romanos" otra vez.

El arquitecto Durand quiso "racionalizar" la arquitectura y declaró que su fin no era la belleza, sino la utilidad, y alzó, con sus discípulos una gran cantidad de edificios pesados y sin gracia, en los cuales sólo la monumentalidad era la razón de su existencia. Contra esta exageración reaccionó el alemán Hittorf, educado en París, policromando sus edificios, pintando las columnas, los frisos y las estatuas, "a la manera del siglo $\mathrm{v}$ en Grecia" y usando piedras y mármoles de muy diversos colores, mientras Huyot, que habia visitado Turquia, propuso construcciones de tipo árabe y bizantino. $\mathrm{Y}$ así resulta explicable que Vaudoyer, en la Catedral de Marsella, hiciera un galimatías de románico, bizantino y florentino del siglo $\mathrm{xv}$, mientras Labrouste, en la biblioteca de Santa Genoveva, recuerda los palacios mediceos, si bien en el interior introdujo por primera vez las columnas y los arcos de hierro.

Pero otra corriente, esa sí distinta, apuntaba al mismo tiempo: la vuelta a la Edad Media con el Romanticismo. Vale la pena recordar estos esfuerzos, porque cuando se habla del Gótico redivivo en Francia, sólo surge en la memoria de los no especializados el nombre de Violletle-Duc, pero, en realidad, este ilustre arquitecto no es más que una rama, desde luego la más vigorosa, del árbol que formaron los que dieron a conocer de nuevo y revalorizaron el entonces desprestigiado arte Gótico.

Desde 1791, Lenoir, al crear el Museo de Monumentos Franceses, reivindicó la arquitectura medieval y en 1816 el conde de Laborde publicó su cronología de la arquitectura francesa de los siglos xir al xv. En 1824, Arcisse de Caumont, escribió un hermoso ensayo sobre El Arte religioso mediezal y en 1830 dió un curso en Caen que, como dice Hatutecoeur, 
"marca verdaderamente el principio de nuestra arqueología medieval". ${ }^{17}$ Con todo esto se apasionaron por la Edad Media los grandes historiadores de mediados del siglo: Michelet, Thierry, Guizot. El barón de Taylor publicó Voyages romantiques et pittoresques en 1830 y Victor Hugo, en 1831, entregó, no sólo a Francia, sino al mundo su Notre-Dame de Paris, cuyo prefacio es el más cumplido elogio y el "primer himno" al arte Gótico.

Vitet llegó a afirmar: "el principio de la arquitectura gótica está en la emancipación, en la libertad, en el espíritu de asociación y de comunidad, en los sentimientos autóctonos nacionales" y esto lo decía el mismo año de 1831, en el cual también Lassus comenzaba respetuosa, sabia y conscientemente, la restauración de la Sainte Chapelle y de Saint Germain l'Auxerrois. Así pues, Viollet-le-Duc se encontró la mesa puesta, pero, sin duda, fue el mejor comensal. Creó en 1848 la "Comisión de Artes y Edificios Religiosos"; restauró las principales catedrales de Francia y publicó su espléndida y definitiva obra, Dictionnaire raisonné de $l^{\prime}$ Architecture française du $X I^{e}$ au XVI" siècles, de 1854 a 1868.

Por supuesto que los aferrados clásicos protestaron, pero perdieron definitivamente la partida. Cuando en 1856 se trató de hacer una nueva iglesia en París, se hizo gótica, claramente gótica, tanto que se confunde con las del siglo xrv. Es la de Santa Clotilde, hecha por el alemán Gau, discípulo de Le-duc. $Y$, claro, se llegó al abuso, como en lo clásico. Todo fue gotizante. "Le pastiche du Moyen Age - dice irritado Hautecoeur- n'était pas moins funeste à l'architecture que le pastiche de l'antiquité." 18

Todo esto produjo otra reacción en el abierto espiritu francés hacia eso "nuevo" que venía. Fue el joven arquitecto Héctor Guimard quien, siguiendo a Horta, como hemos dicho, inició el Art-Nouveau en Francia. De Guimard escribió, al parecer con cierta irónica envidia, el arquitecto y crítico L. C. Boileau: "Il est un homme jeune, grand, brun, avec des cheveux très noires et toute la barbe taillée en point, très élégant, d'une belle tournure; je dirais un Alcibiades..."19 Por lo que dice no creo que tuviera nada parecido con el rubio griego, salvo la hermosura física.

Héctor Guimard, después de su viaje a Bruselas, construye el Castel Beranger - una casa de departamentos- en la rue La Fontaine, termi-

17 Louis de Hautecoeur, en L'Architecture en France de 1789 à 1850, de la Histoire de l'Art dirigida por André Michel, vol. vilf, le. partie, p. 19.

18 Op. cit., p. 38.

19 La citada revista L'Architecture ... p. 127. 
nada en 1899, de la cual hizo un album que llamó L'Art dans l'habitation, con sesenta y tres grabados en color y que causó dos movidas causeries en la Sociedad de Arquitectos de París y publicadas en L'Architecture. Son varias las innovaciones de Guimard a la casa Tassel. El gran arco de entrada descansa directamente sobre el muro, pero dos columnas extrañas se interfieren y segmentan el arco, obligando a las dos últimas dovelas a prolongarse para recibir los capiteles. Las columnas comienzan con tallos vegetales retorcidos; luego surge el fuste cilindrico y después el capitel, de sección cuadrada, adornado de grandes hojas. La puerta de hierro es impecable en cuanto a su nueva y propia estética, con barrotes rectos enmedio para equilibrar las vaporosas curvas del remate. Las columnas son pesadas, pero esta reja tiene la virtud de aligerar el conjunto. El Art-Nouveau (recordemos las palabras citadas antes de Giedion) es arquitectura total, es decir, planta y decoración.

Después del Castel Beranger construyó Guimard las más importantes entradas al Metro del centro de París, en donde la fantasía del dibujo es extraordinaria. Se comenzó a hablar del "estilo Guimard", quien, envanecido, acabó por crear los efímeros pero muy interesantes "estilos" llamados "latigazo", "hueso de carnero", "tenia", "salamandra", que produjeron espanto en cierto público timorato. Pero el "latigazo", como notó muy bien Bayard, fue simbólico, pues hirió de tal manera al pasado que lo inhabilitó con su cicatriz a toda renovación.

Puede ser censurable esta actitud superficial y momentánea de Guimard, pero tiene en su abono sui decidida rebeldía y su afán de libertad. El mismo se defendió de sus enemigos diciendo: "mis principios decorativos son novedosos, pero se ligan a los que ya usaron los griegos; no soy el causante de las nuevas condiciones de nuestra época $y$, en suma, no hago sino aplicar la teoria de Viollet-le-Duc, pero sin estar fascinado por las formas de la Edad Media". ${ }^{20}$

En cuanto a eso de los griegos tal vez lo creyó de buena fe el nuevo Alcibiades, pero estaba errado; en cuanto al arranque de Le-duc, cuya paternidad del Art-Nouveau exageran todos los franceses -y esto es sin el menor menoscabo del egregio arquitecto- no es más que nacionalismo. $\mathrm{Y}$ es injusto de Guimard no mencionar a Horta.

Entre las muchas casas del joven arquitecto hay que citar, con todo elogio, la de la rue Mozart - la casa Tassel de París - hundiendo los vanos de las ventanas $y$ balcones y resaltando el muro de la esquina, en un espléndido equilibrio ondulatorio. En la puerta principal, resaltada

20 L'Architecture, samedi 15 , avril 1899, num. 15, p. 127. 
lo mismo que la ventana, ascienden las jambas y se continúan sin interrupción en el arco, que avanza curvado como en las repisas de los retablos barrocos y se decora de tallos con una delicada melodia de entrelazos. De casas como ésta nacen casi todas las mansiones Art-Nouveau que existen $\longrightarrow$ existieron- en la ciudad de México.

No sería justo olvidar que, anteriores a Guinard, hacían grandiosos esfuerzos de modernidad dos decoradores incansables: Sigfried Bing y Eugène Grasset. El primero, en 1896, abrió la "Exposición Art-Nouveau" en la rue Chauchat, en donde "quiso meter en los ojos de los parisienses lo que sa hacía de más característico fuera de nuestras fronteras" y crear en París "un centrq viviente de arte moderno". ${ }^{21}$ Con ello logró en 1900 imponer los modelos de interiores de Feure, Gaillard, y' Colonna. El segundo fue grabador, litógrafo, diseñador de muebles, de vidrieras y de tapicerías. Grasset tuvo un mal momento - hacia 1880- en el que construía muebles egipcio-indostano-medievales, o carteles de tan mal gusto como los que hizo para una Librairie romantique o para el Chocolat mexicain, pero supo adaptarse a las nuevas formas inteligentemente $y$ su contribución al Art-Nouveau fue de tanta importancia que Gabriel Mourey lo considera - equivocadamente- como su fundador en Francia. ${ }^{22}$

En 1899 se construyó en París el Gran Palacio de las Bellas Artes por tres arquitectos: Deglane, Louvet y Thomas. La escalera, que es lo más ostensible estilo Art-Nouveau, es de Louvet. Al crítico Boileau le pareció, cosa rara, encantadora: "Es la última palabra del género; ha unido felizmente esta vegetación constructiva con las columnas de pórfido verde, de un bello estilo, que sostienen los arcos, los tramos y los descansos. Toda esta obra es de gran interés. La escalera de $M$. Louvet será considerada, sin duda, como una de las obras más curiosas que hayan sido realizadas en este fin de siglo. Pertenece al Art-Nourvean en el sentido característico de la palabra y es de lo mejor porque está sabiamente ordenada y lógicamente concebida, en perfecta conformidad con los nuevos materiales... Louvet ha encontrado en su escalera la poesiał del metal de gran construcción." 23

Hasta "poética" le pareció la escalera al estricto Boileau y, en cfecto, lo es, en digna consonancia con ese triunfo total del acero y del vidrio que es el plafond de Thomas. En cuanto a eso de "vegetación constructiva" casi es una definición del Art-Nouveau.

21 Essai sur l'Att Decoratif français moderne. París, 1921, cap. II, p. 64.

22 Idem, p. 68.

23 L'Architecture, núm. 15, p. 132. 
A propósito de la exposición Le Génie Civil Italien, en 1900, en París, hubo obras de mucho interés pero ya bien poco de Art-Nouveau. Empezó el estilo a desplazarse a provincia y a América. En Grenoble se abrió un café que se llamó, precisamente, "A l'Art-Nouveau", edificado por L. Dufour. En la revista LG Construction Moderne se dice: "Las tiras y los latigazos son, en efecto, una de las caracteristicas del Modern Style (sic). Es un procedimiento de decoración bien simple, pero es necesario saber usarlo; no lanzan el latigazo nada más porque sí, exige una cicrta desenvoltura ... estos ornamentos, que no podríamos calificar de geométricos y que no son tampoco de la flora o de la fauna, no son los únicos que Dufour ha usado en su café; graciosas figuras ocupan sus lugares en el centro de la composición $\mathrm{y}$, como están tratadas según el gusto moderno, su silueta armoniza muy bien con el cuadro que las enmarca." $24 \mathrm{Y}$ se hace notar que la moda del Art-Nouveau "se ha extendido rápidamente a las otras ciudades y los ejemplos de descentralización en el dominio del arte decorativo son muy numerosos".

Palacios, casas, estaciones de ferrocarril y de tranvías, bancos, oficinas, en fin, todo lo que para Reinach no había sido público, fue en estilo Art-Nouveau, en forma decidida y casi febriscitante, lo que muestra su oportunidad y validez. "Hay que aplaudir sinceramente - decía Bayard- este afán de novedad, esta aspiración a crear un ambiente adecuado a nuestra personalidad, a nuestro espíritu. Es una ola que avanza, que se extiende, y resistirse a ella sería confesarse viejo tras una máscara de juventud; por otra parte sería insensato pretender remontar la corriente cuando las aguas elevan todo el impetu de una pasión; por consiguiente, fuerza es dejarse mecer por la corriente, pensando que cada generación debe tener, fatal y afortunadamente, su modalidad."25

Las escuelas, como la del barrio de Grenelle, en París, hecha por L. Bonnier, con sus techos curvos, su vestíbulo en forma oval y sus ventanas ondulantes, fueron Art-Nouveau. Y hasta los sepulcros. Espléndido ejemplo es el de Jules Roche y Girard en el cementerio de Preville, en Nancy, siguiendo el modelo, pero superándolo, del sepulcro de Guimard en Père Lachaise. El copete dè tallos y hojas, las ventanas, de líneas

24 Nún, 2, 20 de octubre de 1900, p. 28.

25 Op. cit., p. 12. 
sinuosas y llenas de gracia, hacen de esta obra algo único. Está toda policromada. El Art-Nouveau, por nuevo, por joven, por rebelde, es siempre alegre y encantador. "Para los vitrales la dificultad consistió en obtener un doble efecto decorativo; colorido por transparencia en el interior y colorido de loza vidriada en el exterior; para lograr este resultado, el pintor-vidriero, supo ligar muy bien los vidrios opalinos americanos y los vidrios transparentes franceses." Estos "vidrios opalinos americanos" no son sino los alabastros de Puebla llamados "tecali", tan olvidados en México desde el siglo xix y que, por fortuna, han resucitado con la buena arquitectura moderna.

Emile Gallé en 1900 en la Exposición de París hizo una mesa que hoy guarda el $V$ ictoria and Albert Museum que es un precioso ejemplar del Arte Nuevo, no sólo como forma, a base de tallos ondulantes y florones, sino como idea, al ponerle una inscripción que es todo un lema del optimismo de la época: Travail est joie. Y Louis Majorelle labró todo un mobiliario de oficina a base de nenúfares egipcios, fundando con él lo que se llamó la "Escuela de Nancy".

Por supuesto que, siendo el Art-Nouveau, a la vez que una solución arquitectónica un estilo eminentemente decorativo, todo el mobiliario fue también de tipo curvilíneo y vegetal, desde los aparadores, mesas, roperos, camas y sillas, hasta los candeleros, los vasos, los ceniceros, las lámparas y los cubiertos de mesa. En el citado café dé Dufour; él mismo se encargó de dibujar todo el mobiliario, desde los mostradores hasta las cucharas.

\section{El Art-Nouveau en Inglaterra y en Alemania}

El gran artista, aparte de otros muchos excelentes, del ModerinStyle en Inglaterra, fue el arquitecto Charles Rennie Mackintosh. Es tan personal y diferente que Tschudi Madsen, un escritor noruego que ha escrito el mejor libro sobre el Art-Nowveau en Europa, ha hablado de sus "ascéticas" obras, con líneas apenas curvadas, pero empleando elementos decorativos como las figuras ovoides y gotas de agua. Sus muebles $y$ en general sus proyectos son efectivamente severos, elegantes, contenidos, tal vez por no caer en la exageración de un Guimard. ${ }^{2 B}$

En Viena hasta tomó un nombre especial. Sezessionsstil, por la unión de pintores y escultores, fundada en 1897 que se llamó Wiener Sezession.

26 Stefhan Tschudi Madsen. Sources of Art-Nouveau. Nueva York. 1955. Pp. 32 a 39 y pp. 131, 286, 289. 
Pero el más personal y destacado, audaz y hasta la exageración, fue August Endell, del cual sólo cito su asombroso "atelier" Elvira, de Munich, como ejemplo de superación de Horta y anticipación de Guimard. La escalera, en donde el tallo y las flores se lanzan como látigos en furioso movimiento; la reja de la entrada, de un dibujo fantásticamente sinuoso y la decoración interior, de hojas, olas, escamas, desorbitadas y de gran tamaño, parecen increíbles para 1897. ${ }^{27}$

El abuso comenzó a echar a perder al Art-Nouveau. Como ejemplo puede verse el increíble Olmo de Escutari que proyectó el arquitecto turco Aram Tahtadjian, cuyo alzado publico sin comentarios pues basta verlo para censurarlo.

Para terminar este ensayo transcribo una crítica de la citada revista L'Architecture: "Después del entusiasmo de la primera hora, en la que todo el mundo se declaró cautivado de la novedad, de la naciente originalidad que prometía esta regeneración del arte, se comienza a percibir que no todo es igualmente nuevo ni original; en todo caso, sus cualidades, cuando existen, no siempre son de buena ley." El arquitecto Hermant declaró que ya estaba cansado del tallo, de la "idiota" flor del girasol, de la "poco geométrica" dalia y del manzano, que, como fue el árbol de la ciencia, "se había abusado de él, simbólicamente, en escuelas y bibliotecas".

Las cintas y fajas desenvucltas, las flores y tallos, los "latigazos", empezaron a aburrir. Un príncipe nórdico declaró: "Ante el Art-Nouveau mi malestar es no sólo estético; es que entre esos objetos barrocos y de líneas incoherentes me mareo; mis movimientos pierden mesura y mis gestos se hacen pueriles è inexpresivos." Pero no olvidemos que este príncipe habla de las obras posteriores a 1910 . No hubiera dicho eso ante Horta o Guimard.

En una causerie de la revista citada de La Construction Moderne, el crítico Planat exclamó: "Tout le monde commence à regimber." 28 $Y$ en Granada, en la plaza del Picón, existe una casa Art-Nouveau a la cual se puso este letrero: "De esta fachada no es responsable el actual propietario." Así es el tornadizo capricho del hombre.

Esté ferror naturalista del Art-Nouveau se acaba hacia 1914. Vuelven, fatalmente, los elementos renacentistas: los arcos de medio punto, los almohadillados, los atiántes, las cariátides y las columnas y pilastras

27 Tschudi Madsen, op. cit., p. 422. S. F. y Ahlers-Hestermann, Stilnende, Berlin, 1956, p. 40.

28 Núm. 16 de marzo de 1901, p. 277. 
clásicas. La delicadeza del Art-Nouveau se disuelve. Ya no se desean ni el tallo, ni la hoja, ni la flor.

La primera guerra mundial acabó con el Art-Nouveau. E1 cubismo en pintura y el llamado "funcionalismo" en arquitectura, desnudo y frío, expidieron su partido de defunción.

\section{Resumen final}

¿Qué es el Art-Nouveau? Es, desde luego, la ruptura final con los estilos "históricos", es decir, los anteriores a 1890 . No es cierto que provenga del Gótico; no es una reconstrucción de ese estilo, pues si el Gótico fue un arte eminentemente religioso, el Art-Nouveau es, ante todo, un arte eminentemente civil. No hay templos ni mobiliarios eclesiásticos estilo Art-Nouveau (La iglesia de la Sagrada Familia, de Gaudi, es neogótica más que $A r t-N o u v e a u$ ).

El Modernismo tuvo un gran problema: enfrentarse con el industrialismo avasallador de su época. Con la perentoria necesidad de usar los nuevos materiales: el cemento armado, el acero, el hierro, la lámina, reaccionó en la forma debida. De Vogue decía: "El hierro ha destronado a la piedra y a la madera; el hierro se hace artístico, ya que busca sus medios de expresión en su propia naturaleza, por su ligereza y su elasticidad. La belleza no es sino la armonía entre la forma y el uso a que está destinada una cosa." 20

El industrialismo traía una ineludible urgencia de construcciones nuevas. $\mathrm{Y}$ todas civiles. Volver a la Naturaleza fue la mejor solución. $\mathrm{El}$ dórico o el gótico no resolvian la arquitectura bancaria o fabril. A nueva época, nueva técnica y nueva forma. Los problèmas del ArtNouveau no fueron religiosos ni morales; fueron científicos y estéticos. En el siglo de Haeckel y de Darwin era lo "naturalista" lo adecuado para representarlo. De aquí también - dicho sea de paso- la presencia del paisaje en la pintura del siglo xrx.

Sin el Barroco no existiría el Art-Nouveau. El tallo de Horta, la hoja, la flor el sinuoso movimiento de los vegetales, la suave ondulación de las ramas, la multiplicación mixtilínea de la Naturaleza, están tanto en el Gótico como en el Bartoco. Porque la línea recta, el ángulo, las

29 Citado por Bayard, p. 78. 
plantas arquitectónicas en espacios rectos, se habían usado siempre. En el Barroco y en su último discípulo, el $A r t-N o u v e a u$, vendrían los sentidos a ver $\mathrm{y}$ a tocar lo mórbido y vital de la línea curva que, como una melodía wagneriana, ondulante y reiterativa, se solidifica en esta arquitectura audaz y rebelde que es la liquidación, no sólo del siglo xIx, sino la del Barroco.

¿ Por qué el Art-Nouveau comienza con el hortiano tallo? Nace de la ineludible necesidad de torcer el hierro, porque en su solo ser rectilíneo, en su esquelética dureza, hubiera dado una impresión desoladora. El sér humano no es monótono, ni "uno", ni "puro". El hierro tuvo que doblegarse a la voluntad y gusto del hombre. E1 "acariciarlo", como dice un crítico de la época, fue no sólo un acierto, sino una perentoria necesidad. Por otra parte, no era posible quedarse nada más con el tallo; vinieron la hoja y la flor y todo lo que se pudo y se quiso tomar de la Naturaleza.

El Art-Nouveau creó nuevos tipos de capiteles, fuera de los órdenes clásicos, medievales o barrocos, sin acantos ni volutas, sino con hojas y flores diversas, cabezas, rostros. Jambas, dinteles, repisas, balaustres, antepechos, fueron como floreros o jardines en un afán decorativo que no ocultaba la arquitectura; al contrario, la subrayaba. "Es una nueva primavera - dice el muy citado Bayard- un florecimiento de motivos decorativos de molduras; es una presentación en un equilibrio inédito que llevará el sello de nuestro pensamiento y de nuestro gesto." $30 \mathrm{Y}$ un teórico del movimiento, Jules Simon, declaró: "No se conserva la realeza de la moda por medio de imitaciones, por más perfectas que sean. Hay que inventar para dirigir. Sin originalidad puede uno marchar a la cabeza de su profesión, pero no la dirige."

Hay que darse pues muy buena cuenta del enorme valor que tiene el Art-Nouveau como "puente" necesario entre los "estilos históricos" y el Arte Moderno y contemporáneo. Sin él su presencia se hubiera retardado. Es el estilo artístico más efímero que conoce la historia, pero justamente en esa su agonía - su lucha- estriba su gloria.

Me place citar aquí la opinión sobre el Art-Nouveau del más destacado historiador y crítico de Arte Moderno de México: Justino Fernández. Dice: "En el Art-Nouveau late un sentimiento de humanidad que da su lugar a la razón y a la sin razón, que revela una libertad, que toma elementos orgánicos y los humaniza al estilizarlos para que sean ornamentales, pero no se quedó en eso; las estructuras mismas adqui-

30 Op. cit., p. 120. 
rieron ondulaciones increibles $\mathrm{y}$ aun las techumbres, cornisas, columnas y cuanto hay; un soplo de vida, y de vida nueva, animó las formas arquitectónicas, antes rígidas y señeras desde el advenimiento del Neoclásico; el sensualismo penetró en ellas y no por la profusión de elementos, sino por el movimiento que el Art-Nouveau supo darles, renovando todos los barroquismos anteriores y enlazándolos con el Romanticismo, entendiendo éste, como diría Baudelaire, como la expresión más actual de lo bello, no como reconstrucción arcaizante." 31

El Art-Nouveau comenzó a morir con el abandono de la Naturaleza. Los arquitectos Charles Girault y Charles Plumet fueron sus sepultureros al crear la pesada arquitectura llamada del bow window, en donde se vuelve a ciertas formas renacentistas $y$ se inventan esos balcones que avanzan atrevidamente sostenidos por ménsulas o atlantes (bow quiere decir proa) y que nada tienen que ver ya con la ligereza del Art-Nouveau.

No puedo pasar por alto un artículo publicado en la revista Connaissance des Arts titulado: "Primicias de un artículo que será publicado dentro de cuarenta años", por Yvan Christ. Supone el autor lo que se dirá en 1996 del Art-Nouveau, el cual será regido por una legislación protectora y sus principales edificios serán declarados Monumentos $\mathrm{Na}$ cionales. En la presentación de una hermosa casa de le rue Claude Cahu, $N^{\varphi}$ 9, dirá el futuro articulista: "La fachada está revestida de estuco esmaltado amarillo; este recurso a la policromía monumental se usó en $1900 \mathrm{y}$ es el antecedente de lo que hoy trata de imponer la escuela de Le Corbusier." (Si conociera el señor Christ la policromada Ciudad Universitaria de México vería que no hay que llegar hasta 1996) y ante el Metro de la plaza de la Bastilla, de Guimard: "Esta obra mezcla en un juego barroco de curvas y contracurvas el hierro, el vidrio, la madera, la cerámica; la ruptura con el academismo clásico es completa; los motivos vegetales y florales están utilizados tan juiciosamente que logran una extraordinaria invención plástica... se comprende que una obra tan acabada debe ser conservada como un portal del siglo $\mathrm{xv}$ o un mobiliario del xvru." Los anticuarios comprarán fachadas y ventanas, hierros y vitraies modernistas y recordarán la frase de Le Corbusier: "Les ar-

31 Arte Moderno y Contemporáneo de México. México. Imprenta Universitaria. 1952, p. 253. 
chitects de cette époque ont été des chercheurs formidables", que no sé si es auténtica o el señor Christ se la colgará a fines de esté siglo. ${ }^{\mathbf{8 2}}$

\section{El Art-Nouveau en México}

Hemos llegado, por fin, a México, en donde el $A r t-N o u v e a u$ tuvo su gran momento como en ningún otro país de América. Ha sido enormemente destruído y la documentación es muy escasa, por lo cual no puede tener esta parte la extensión que sería de desearse en este ensayo.

Nos llega, porfíricamente, de Francia, al través de los ricos burgueses $y$ financieros que formaron la corte presidencial, entre los cuales hubo algunos y muy prominentes, de origen francés. Las nuevas colonias que comenzaron a formarse a principios del siglo, la Roma y la Juárez, principalmente, fueron Art-Nouveau por excelencia, pero en toda la ciudad, de Tacubaya a Santa María, hubo magníficos ejemplos del estilo. Los planos de las casas y los dibujos de las fachadas $\mathrm{y}$, a veces, hasta los propios arquitectos venían de París. Esto no quiere decir que no hubiese muy buenos arquitectos mexicanos del Art-Nouveau.

Un arquitecto italiano, Adamo Boari, que ganó el Concurso Internacional para el Teatro Nacional, fue el corifeo del Art-Nouveau en México. Al llegar al país trató de hacerse grato y en 1900 proyectó un monumento al Presidente. Se elevaba sobre una pirámide prehispánica con adornos de serpientes y máscaras; sobre ella iba un grupo de columnas rodeadas de ángeles (!) y encima don Porfirio, a caballo. Por fortuna esto no pasó de proyecto y de ser "una locurita romántica", como dice Justino Fernández.

Muchas obras hizo Boari, unas buenas y otras malas, pero en ArtNouveau sólo dos: su propia casa y el Palacio de Bellas Artes. Su casa fue arrasada hace unos cuantos años de manera egoísta, torpe e innecesaria. El Palacio de Bellas Artes (nombre muy a la francesa fraguado después, ya que comenzó como "Teatro Nacional"), lo dejó a medias.

Boari trató de hacer un Art-Nouveau "mexicanizado", por lo cual asoman en muchas parte cabezas de tigres y coyotes y unas poderosas serpientes ondulan en los arcos de las ventanas del primer piso. Esta decoración, tan inteligentemente ideada por Boari, le da al Palacio de Bellas Artes una categoría única. Toda esta zoología mágica alterna con las esculturas, hechas en Europa a lo Carpeaux, pero las columnas del pórtico, con su gálibo sutilmente ondulante, las máscaras y festones,

32 Núm. 54, agosto de 1956. 
los adornos de las cornisas, los capiteles y las rejas son absolutamente Art-Nouveau. Todo fue extranjero en el Teatro Nacional. Las esculturas, en mármol de Carrara fueron obra de los italianos Bistolfi, Boni, Giorenzo y Marotti; los finos y aéreos pegasos, del catalán Querol, y hasta la cortina de vidrio del escenario, muy Art-Nouveau, con el paisaje de los volcanes, fue ejecutada en los Tiffany Studios de Nueva York. La cimentación la calculó -iy qué mal! - el especialista W. H. Birkmire y la ejecución la hizo la firma Milliken Bros, de Chicago. $1 \mathrm{Ni}$ un solo mexicano intervino en este retrato del porfirismo!

Sigue en importancia al Palacio de Bellas Artes la gran tienda "El Centro Mercantil", que diluye el absurdo de su fachada con su interior, armoniosamente concebido en puro Art-Nouveau. Todo "funciona" alli. Las barandillas de los pisos se abultan para mostrar la mercancía; la escalera se desenvuelve en ondas que facilitan la subida, con un rico y acaracolado barandal. Los ascensores, jaulas de ondulantes barrotes, se deslizan lentamente y nos permiten ir viendo toda la tienda. De estos ascensores dice Gómez de la Serna que son "como acuarios secos en los que viven algas de hierro, aunque se han muerto los peces". Pero es que los peces - nosotros- podemos mirar a través de las algas de hierro sin la criptofilia de los actuales elevadores en los cuales, por no tener qué mirar y por no clavar nuestros ojos en el pasajero que va enfrente, con esa molestia que implica la mirada en dos seres desconocidos, entonces hay que ver el suelo o los números de los pisos que se van sucediendo, con un secreto y agudo deseo de llegar pronto. Mas es el techo, el plafond, lo más extraordinario de este ejemplo magnífico de una época. Un enorme vitral da luz y color a la tienda. Los ejes y travesaños de hierro que lo sostienen se enriquecen en el centro, en donde tres óvalos se rehunden con doble faja de vidrios policromados; después, una suave curva de tres tramos en los que los dibujos de los vidrios son diferentes, baja y se apoya en el muro. La electricidad sobra aquí. Es la luz solar, filtrándose a través de este rico plafond la qué ilumina todo "El Centro Mercantil", que esperamos se conserve siempre así - ¿será posible esto en México?- como un ejemplo de nuestro pasado inmediato. 
La joyería de "La Esmeralda" es menos Art-Nouveau. Sus balcones convexos derivan de un trasnochado renacimiento, pero lo que sí le da categoría modernista es su curvada y ondulante escalera de hierro, iraída directamente de París y allí fabricada.

Recordemos ahora las casas que restan en la ciudad de México. En la antigua avenida Tacubaya, No 46, hoy llamada Pedro Antonio de los Santos, está uno de los más ilustres ejemplos de residencia ArtNouveau, ya desmantelada para destruirla y hacer un cine. En París la cuidarian para 1996, cuando menos, como desea Christ, pero en México ya se come ansia por derribarla $y$, claro, mal sustituirla por un huacal $o$, lo que es peor, por un salón muy recargado de motivos versallescos o con esculturas griegas por algún decorador oligofrénico. $\mathrm{Y}$ aqui cabe recordar a Gautier cuando exclama asustado en' su Viaje a España: "¿ Pero es que no hay espacio suficiente en la Tierra para construir sin destruir?" iInocente Gautier! E1 espacio en las ciudades es oro y el oro es el alimento de los ávidos vientres (a pesar de que están repletos) de los egoistas millonarios.

Pensada y realizada como habitación elegante y cómoda; labrada en piedra para un futuro que creyó ser eterno, se alza la hermosa casa explicándonos su prosapia. La fachada principal, en la avenida con amplios balcones, su puerta de acceso con escalera de dos tramos ondufados y un vano más grande, en la esquina, para el comedor. Los lazos vegetales encima de ventanas $y$ balcones son de fina labor y la magnífica cornisa juega en lo alto adelantándose y ondulando en la esquina y en el centro para seguir la curva de los balcones principales.

En la fachada sur lleva una doble terraza, la familiar terraza donde se tomaba el té en el verano, con unas pilastras tan peculiares, tan originales y revolucionarias, que, sin ser los feos árboles de piedra de Gaudí, son como vegetales erectos, llenas de nudos leñosos; la escalera, dignisima, es también de dos tramos ondulatorios con un antepecho de curvados lazos. En la parte posterior se petrifica un mirador también doble, como para contemplar en las tardes de verano la lluvia o en el otoño los atardeceres, con columnillas adosadas como helechos, los arcos curvados en forma de $\mathrm{S}$ y los entrepaños cuajados de flores, sobre todo de margaritas y girasoles. 
Otra mansión, también completa en fachadas e interiores, está en la calle de Londres, NQ 25.

El techo del vestíbulo se sostiene por medio de finas columnas con exuberantes capiteles en los que cuatro molduras o fajas detienen una canastilla interior de la cual brotan flores, tanto por los bordes como por la parte de abajo, entre las fajas, a modo de festones. Los balcones ondulan sus repisas y antepechos, pero sus balaustres son más bien neoclásicos que Art-Nowveau. Este estilo, sin embargo, triunfa en los tallos y hojas y flores de los adornos de los paños laterales, tratadas las hojas, por cierto, a la manera del rococó. La flora triunfa en todas partes, en las cornisas sobre todo, $y$ en los dinteles de los balcones superiores donde asoman, además, rostros de doncellas. El dibujo de los marcos de los vidrios lleva la misma voluntad curvilinea que los tallos. ${ }^{33}$

En la calle de Guanajuato, No 63 , existe una pequeña casa que es excepcional. E1 tallo de Horta se ha convertido aqui en el tronco, en un tronco estilizado hasta convertirse en un chorro de agua solidificada $y$ que, al terminar, con flores çomo borlas, nos da la impresión de un cortinaje. La puerta abre un vano ondulatorio y después el tronco diluído que le hace marco, en forma de herradura, en la cual, a modo de descanso, van unas especies de puntas de diamante aplastadas, únicos elementos que se dibujan con líneas rectas; después, todo es ondas, gruesas ondas que terminan, bajo el copete y a sus lados, en capullos de azucenas, flores y hojas. En los balcones son éstas, enormes, las que se extienden en el ondulante tronco $y$ en las flores-borlas La cornisa engruesa más y se desliza, armónicamente, subiendo y bajando en curvas iguales que pueden darnos la impresión de una ola, de una serpiente o de un "artístico" chorro de crema en un pastel. Y esto era lo insólito, lo rebelde, lo revolucionario. Es posible que choque a muchas personas de gusto depurado, pero habrá que recordarles que el Art-Nouveau es ese paso heroico del pasado hacia un futuro que ni él mismo conocía pero al cual, decididamente, abria la puerta.

33 Acaba de ser destruída (marzo de 1957). 
En la calle de Chihuahua, No 78, está una de las obras Art-Nouveau más características y más afortunadas. Está firmada. Es de "Arquitectura Prunes". que fue algo así como un sindicato de arquitectos y constructores que existió, a principios de siglo, en la calle de Jalapa No 138.

La sabiduría Art-Nouveau con que está hecha es perfecta. La línea curva es la única directriz - salvo los barrotes de los balcones superiores- y el tronco-cortina dibuja su puerta, su balcón principal, doble, sus ocho simétricos balcones a los lados. De las cornisas o molduras divisorias de los pisos caen flores y hojas y la mórbida ondulación de los balcones termina en flores inmensas de grandes pistilos cadentes. Los marcos de los vidrios ondulan también a compás y en los antepechos de los balcones inferiores unas especies de $\mathrm{S}$ hacen función de balaustres. La impresión general de esta fachada, movida con delicadeza, es un descanso. Ni la agresividad de lo barroco ni la impasibilidad de lo clásico. Algo femenino hay en este Art-Nouveau, algo adolescente y tierno que lo hace encantador.

Otra casita deliciosa es la de la calle de Prim, No 39. En la puerta se hunde el arco de media herradura y los lazos de hierro serpentean con sabia fruición en las puertas de madera. Un grueso tronco se inicia en la arquitectura $y_{1}$ sube hacia el balcón; al cual sirve de repisa. El mirador de madera y vidrio da el toque parisino de la casa. Las rejas de balcones y ventanas, ya a punto de abandonar el Art-Nouveau, combinan, roleos con líneas rectas, pero en cuyos cruzamientos brotan flores.

En el No 12 de la misma calle de Prim la mansión es de piedra, con magnífica labor de talla. Ya no es puro Art-Nouveau. Es la aceptación del compromiso entre éste y el neorrenacimiento de principios del siglo. Sus barandillas son, sin embargo, purísimo Art-Nouveau, de tallos. y alguna que otra flor. (Acaba de ser destruida.)

Allí cerca, en la esquina de las calles de Prim y Versalles está una fea casa que ya ni es nada, pero que conserva, como último elemento, 
unos hierros en formas vegetales deteniendo el alero de la pequeña terraza y las ventanas se enmarcan con tallos terminados en girasoles. Ya es un trozo apenas de lo que fue esta reja. ${ }^{34}$

De menos carácter, pero todavía cumpliendo con el Art-Nouveau, es la casa de la calle de Nápoles $N^{\circ} 33$. Ya las fajas de cantera del entresuelo, el almohadillado de los paños del primer piso y los restos de dinteles y jambas de los balcones nos indican la huída. Pero los marcos de los vidrios aún ondulan y las rejas de los sótanos y balcones són claramente Art-Nouveau, llenos de roleos, tallos y hojas. Hay que hacer notar su precioso barandal de hierro $\mathrm{y}$, sobre todo, la decoración escultórica que lo sostiene, con sus ménsulas florecidas; parecen una reja de hierro en donde al cruzarse los travesaños se fijan unas pequeñas flores y otras, mayores, que son grandes rosas, van en el centro. Tan importantes fueron las rejas que aqui se copian en piedra. En medio, sobre la hermosa hoja de acanto erguida en que se convierte la clave de la puerta, un

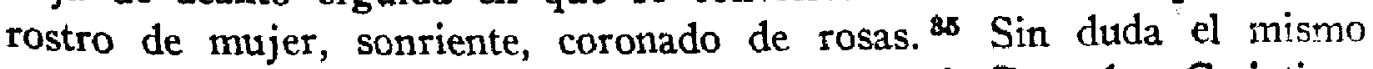
autor de esta casa es el de la No 82 de la calle de Donceles. Casi tiene los mismos marcos ondulantes en ventanas y balcones, pero aquí ha combinado, a pares, los antepechos de los segundos, ya que alterna los troncos o tallos, de piedra en unos y' el hierro forjado en otros. En éstos, para compensar la falta de piedra, hace que se junten balcón y ventana por una continuación de molduras vegetales. El balaustre de la azotea es magnífico: unos tallos ondulan hacia arriba $y$, al chocar con el pasamanos arrojan una flor. Sobre los balcones de piedra, el balaustre luce un penacho de tallos y hojas; sobre los de hierro se aplaca y unta un grueso tallo en el pilar que separa los tramos.

En la calle de Nápoles, $N^{\circ} 46$, hay una variante. Ya puertas $y$ balcones permanecen en la quietud de la línea recta o del medio punto, pero todos los balaustres son unos alcatraces que han elevado sus hojas, volteando apenas los bordes, para sostener los pasamanos y las volutas y roleos decorativos están esculpidos con una fina sensualidad, gozosos de ondular $y$ enroscarse con una especie de secreta morbidez. Los vitrales, con ramos de hojas y flores de color ondulan con la misma displicencia.

En la casa No 54 de la Plaza Río Janeiro hay una escalera, la de entrada, con solución Art-Nouveau, muy bien resuelta y elegante, a pesar

34 Destruída o arrancada de su sitio a últimas fechas.

35 Destruída en mayo de 1957. 
de su estrechez y de desarrollarse entre columnas dóricas. Es de 1914, construida por Daniel Ruiz Benítez.

La casa de la esquina de Colima y Córdoba abomba sus balcones cuajados de flores y las rejas de los sótanos son de tallos ondulantes. Su idea, su dibujo, son puro Art-Nouvean, pero no su material: el cemento. El Art-Nouveau auténtico trabajó en piedras o en mármol.

Una de las casas más fieles al estilo y más exquisitas es la No $H 1$ de la calle de Florencia. La puerta principal adorna su arco con gruesas flores y frutos; el medallón superior, como una joya de las que llevaban al pecho las señoras, con camafeos o miniaturas, divide la puerta de las dos ventanas que iluminan el vestíbulo, como dos ojos alargados de un ser fantástico y la ventana de la sala, más ricamente adornada que la puerta, sostiene el ligero balcón de finos hierros. En el interior la escalera caracolea como la de Horta en la casa Tassel, pero la planta es rígida, obligada por el terreno cuadrado en que le tocó erigirse. Es de 1905.

Ya casi fuera de estilo, con una categoría más bien cursi, es la casa No 93 de la calle del Ciprés, con nidos de palomas en los balcones; sin embargo, el neobarroquismo de sus chorros de hojas y flores proviene del Art-Nouveau.

En la Av. Revolución, No 492, en Tacubaya, la casa es ya apenas un recuerdo de Art-Nouveau por las formas oblicuas de los arcos de las ventanas y de la puerta principal. Ya es de 1920 , cuando el verdadero Art-Nouveau estaba muerto.

En la calle de la Santa Veracruz, No 43 existe uno de los interiores Art-Nouveau más finos y más auténticos de la ciudad de México. La casa 
tiene de todo: el patio es andaluz; la sala estilo Luis XV; una recimara es renacentista. El Art-Nouveau está en la puerta de entrada; en el comedor; en el salón de música; en la antesala y en la recámara "đe los pavos reales".

Todo fue dibujado, paciente y concienzudamente por su dueño $y$ dichoso habitante el Lic. don José Luis Requena, en los años de 1907 y. 1908. Decoración, mobiliario, cristalería, rejas, cubiertas, marcos, todo en fin, fue imaginación del Lic. Requena aprovechando sus viajes a la Europa de fin de siglo. El pintor que ejecutó sus ideas fue don Ramón Cantó, catalán, conocido por ser el que ilustró las pastas, capitulares y grabados de la famosa historia México a través de los siglos.

$\mathrm{El}$ comedor, de techo ligeramente abovedado, está cubierto de lazos de madera que hacen marcos a la decoración pictórica, toda de hojas en forma de corazón, de color verde claro, destacándose en un suave color de rosa del fondo. La chimenea es algo peculiar, pues del hogar brotan llamas, llamas de madera, que al final, en los lazos que envttelven las repisas, se convierten en caracoles de humo.

Al fondo, rodeando al torno que une a la cocina está un aparador para vajilla y mantelería cuyo copete, calado con fina arborescencia de tallos, se refleja en un espejo interior. Las puertas al lado del torno están pintadas, sobre fondo de oro, con dos alegorias: La Primavera y El Otoño, por Cantó, con un estilo claramente prerrafaelista, a lo Rossetti o lo Burne Jones.

El paso del comedor al Salón de Música se efectúa por medio de un arco semiovalado, tan caro al Art-Nouveau, con una cortina de hilos. de cuentas, peculiar de la época.

En la antesala un arco puramente decorativo, de tallos, hojas y flores caladas en sus - digamos- jambas, todo de madera, divide la escalera del tercer piso de la propia antesala.

La recámara de los pavos reales se llama así porque los pies de la cama los forma un pavo real haciendo el abanico y también pavos, con las colas bajadas, decoran el tocador y las sillas, hechas estas de flores $\tan$ menudas y graciosas que más parecen flores artificiales que objetos. para sentarse.

Sin hablar de la espléndida sala Luis XV, que no nos compete, creemos que es el interiot más interesante $\mathrm{y}$ completo que existe en la ciudad de México de una mansión típica de principios de siglo. 
Hay que recordar el curioso mobiliario Art-Nouveau de la Sala de Armas de don Porfirio Díaz en su casa de la calle de Cadena. "El armazón de toda la sala - dice "El Mundo Ilustrado"- lo constituye una plancha de cobre oxidado en verde; los marcos de los balcones son de acero en parte pulido y los cristales están esmaltados a fuego, siendo de un tinte azul oscuro y lucen plumas de pavo real." Pero lo más interesante era el escritorio, "un cofre de piel de Rusia de color granate, saliendo de él un monstruo, representación de la guerra, que extiende sus alas de color verde y cuyas garras de oro bruñido se apoyan en grandes cañones de acero... en el centro del techo vese un tragaluz, cuyos vidrios esmaltados semejan un ocaso, con el sol y la luna...". ${ }^{36}$ Esto era en 1906. La decadencia del Art-Nouveau comenzaba, a pesar de que se hacían aún algunas hermosas casas en las nuevas colonias de México. En París ya sucedian nuevos estilos.

Pero no hay que pensar que el Art-Nouvean en México fue recibido con beneplácito por todos. El 26 de septiembre de 1903, en un artículo del periódico "El País", en el que se ataca a don Justo Sierra por su menosprecio al Arte Colonial y, sobre todo, a la pintura, dice el autor: "Pintores fueron estos (los coloniales) a quienes no podrán compararse ciertamente los que en estos tiempos habrán de salir de una Academia como la dirigida por Rivasi Mercado, donde no tienen asiento verdaderos maestros, sino aficionados, cuya inconciencia artística les permite lanzarse por los caminos de la admiración del Art-Nouveau y las demás zarandajas que, en todas las esferas, se pretende hacer pasar por alto y verdadero arte." ${ }^{37}$

Y para terminar, ¿qué va a pasar con la arquitectura de México anterior a 1925? La respuesta es sencilla: la arquitectura prehispánica se defiende sola; nadie va a derruir una pirámide; la arquitectura colonial tiene a su favor algunas raquíticas, parciales y mal elaboradas leyes que la defienden; la arquitectura del siglo xIx y principios del siglo $\mathrm{xx}$ está totalmente indefensa y será destruída toda. Se olvida esta

36 Año XIII, tomo I, núm. 25, 17 de junio de 1906.

37 Reproducido en El Arte en México, de Manuel G. Revilla, edición de 1923, p. 157. 
afirmación de Sigfried Giedion, con la cual termino este estudio: "El cuerpo entero de una ciudad pone en evidencia, fuera de dudas, la condición del pensamiento arquitectónico de una época. $Y$ la ciudad que permite distinguir a tal punto cada época, se hace capaz de organizar su propia vida." La pobre ciudad de México, abandonada en las egoístas manos de los mercaderes, sin que una superioridad legal la gobierne, "no es capaz de organizar su propia vida".

La ciudad de México ha vivido muchas épocas: la feudal, la renacentista, la barroca, la neoclásica, la europeizante, la Art-Nouveau, la neoazteca, la neocolonial, la funcional... y todo en los límites que van de la Tacubaya a Peralvillo y del Paseo de la Reforma a San Lázaro. Menguado sitio para tanta historia.

Cada época ha destruído con fervor la que le precede porque no ha sabido respetar su pasado, ni desplazarse, ni buscar nuevos espacios.

$\mathrm{Y}$ todo urbanista, en lugar de abarcar la mirada, la clava en el "centro" de la ciudad, el cual, como una larva que no sabe que va a ser mariposa, se revuelve en su capullo sin ambiciones de volar. 
DOI: http://dx.doi.org/10.22201/iie.18703062e.1957.26.2444 


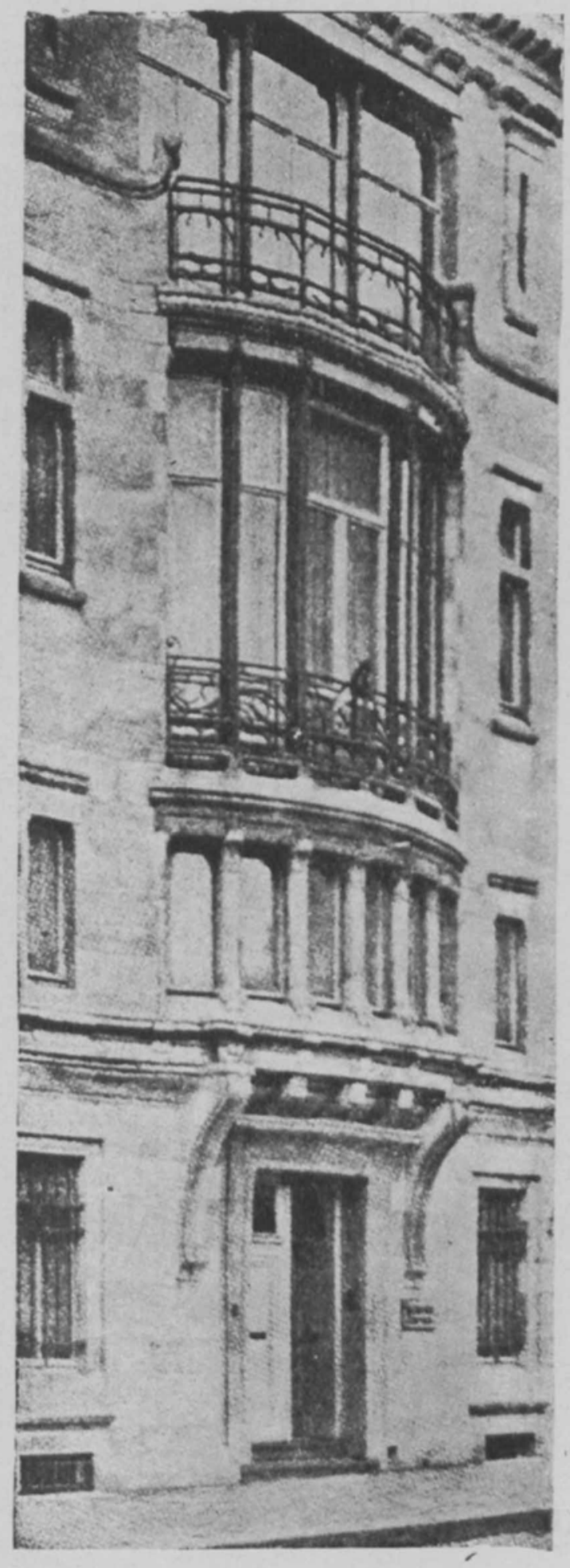

1. Bruselas. Casa Tassel. (Foto cortesía de la Embajada de Bélgica.) 


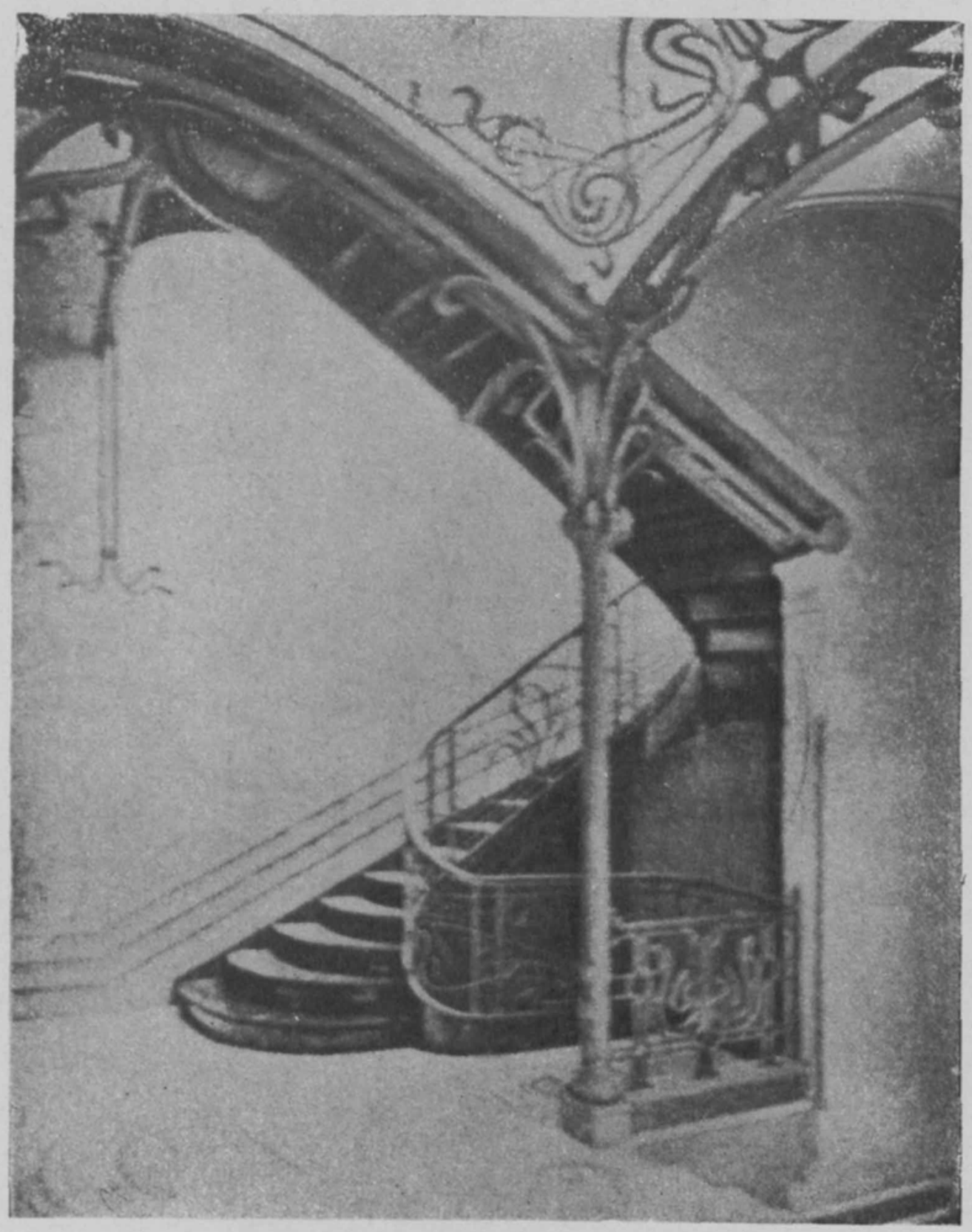

2. Bruselas. Casa Tassel. Escalera, (Foto cortesía de la Embajada de Bélgica.) 


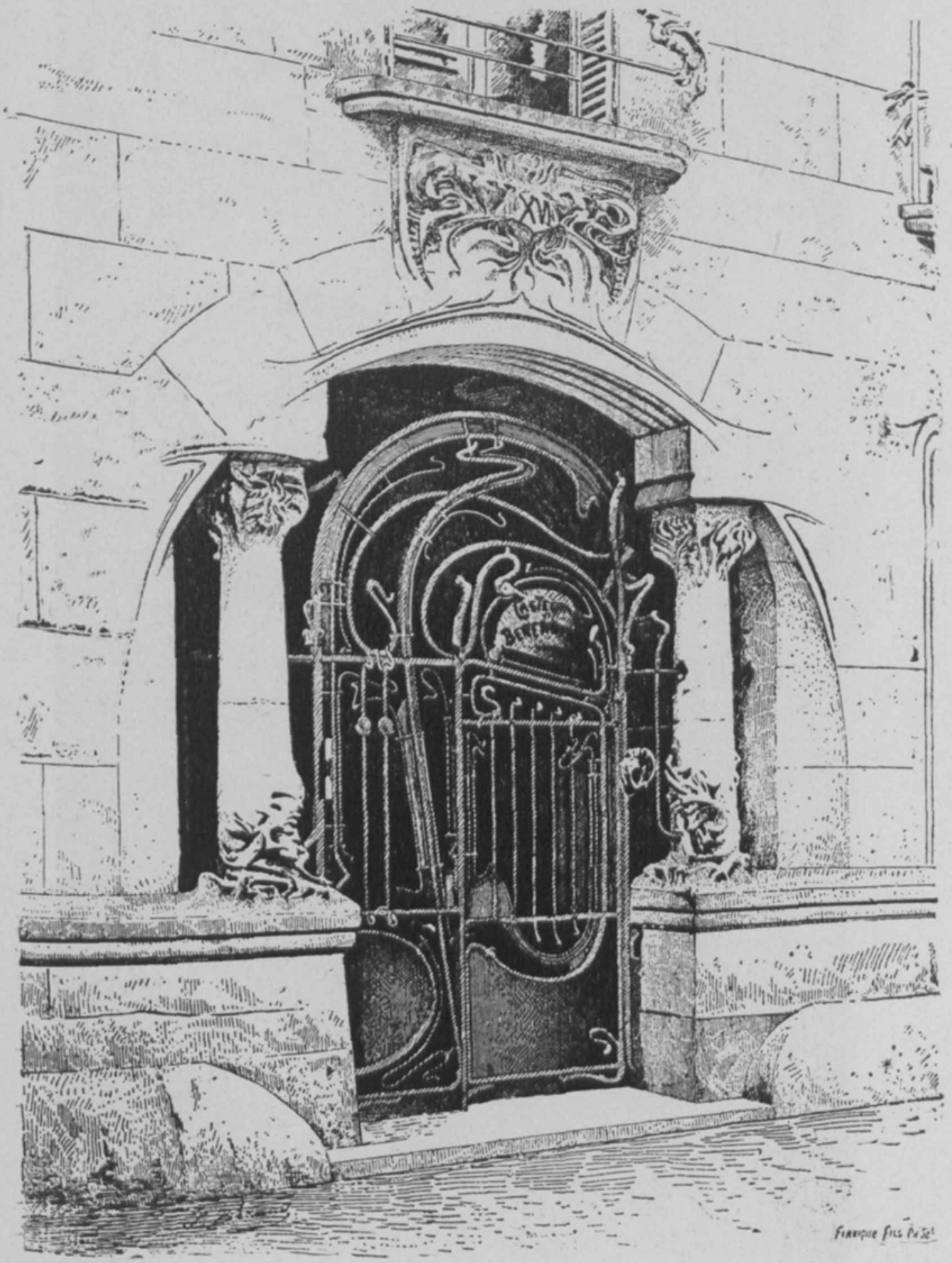

3. París. Castel Beranger. (Cl. de la revista L'Architecture, año XII, $\left.\mathrm{N}^{\circ} 1.\right)$ 


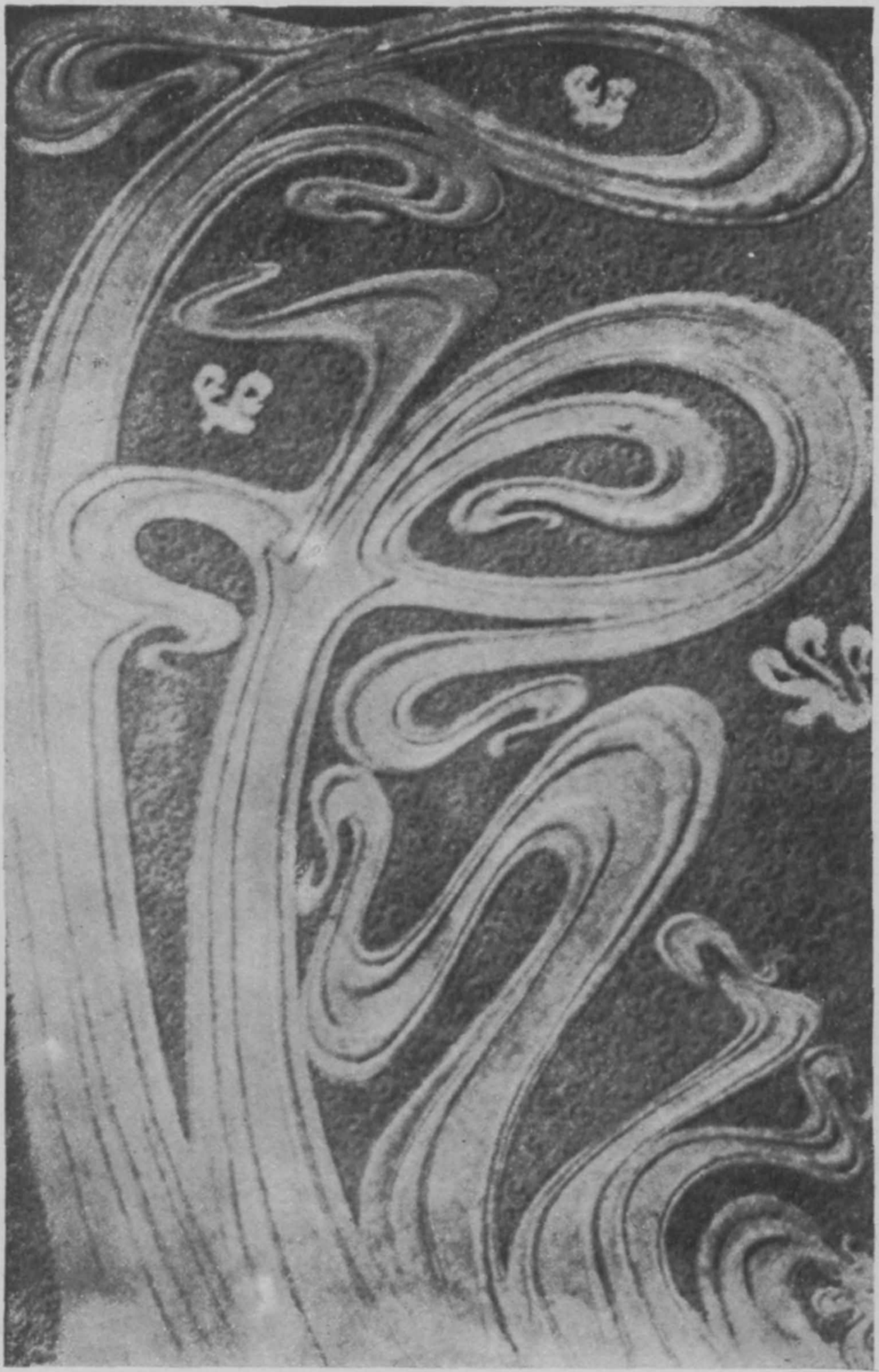

4. Decoración para el Castel Beranger.

(C1. de L'Architecture, año XII, $\left.\mathrm{N}^{\circ} 15.\right)$ 


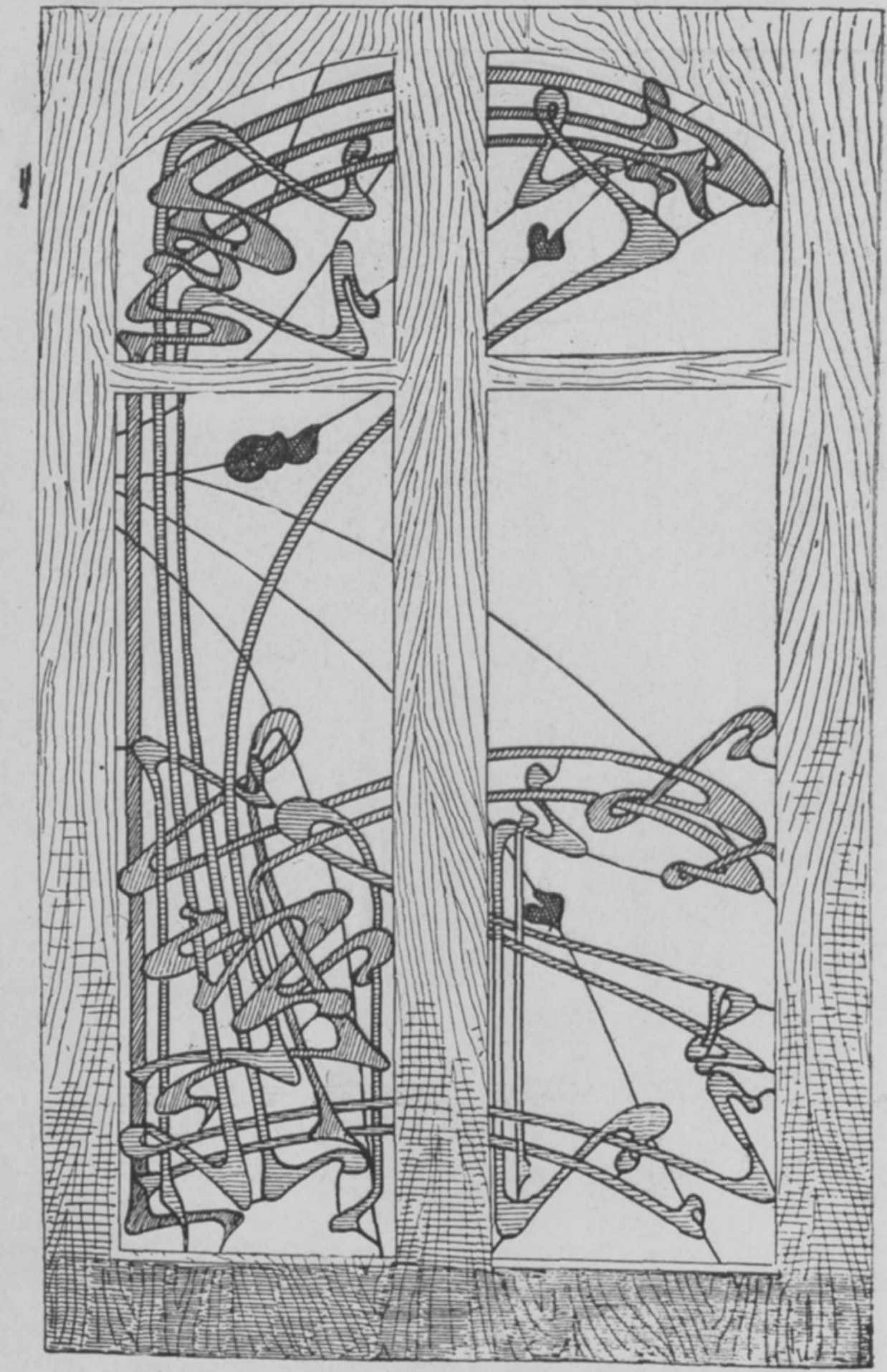

5. París. Dibujo de un vitral Art-Nouveau.

(Cl. de L'Architecture, año xirn, $\left.\mathrm{N}^{\circ} 15.\right)$ 


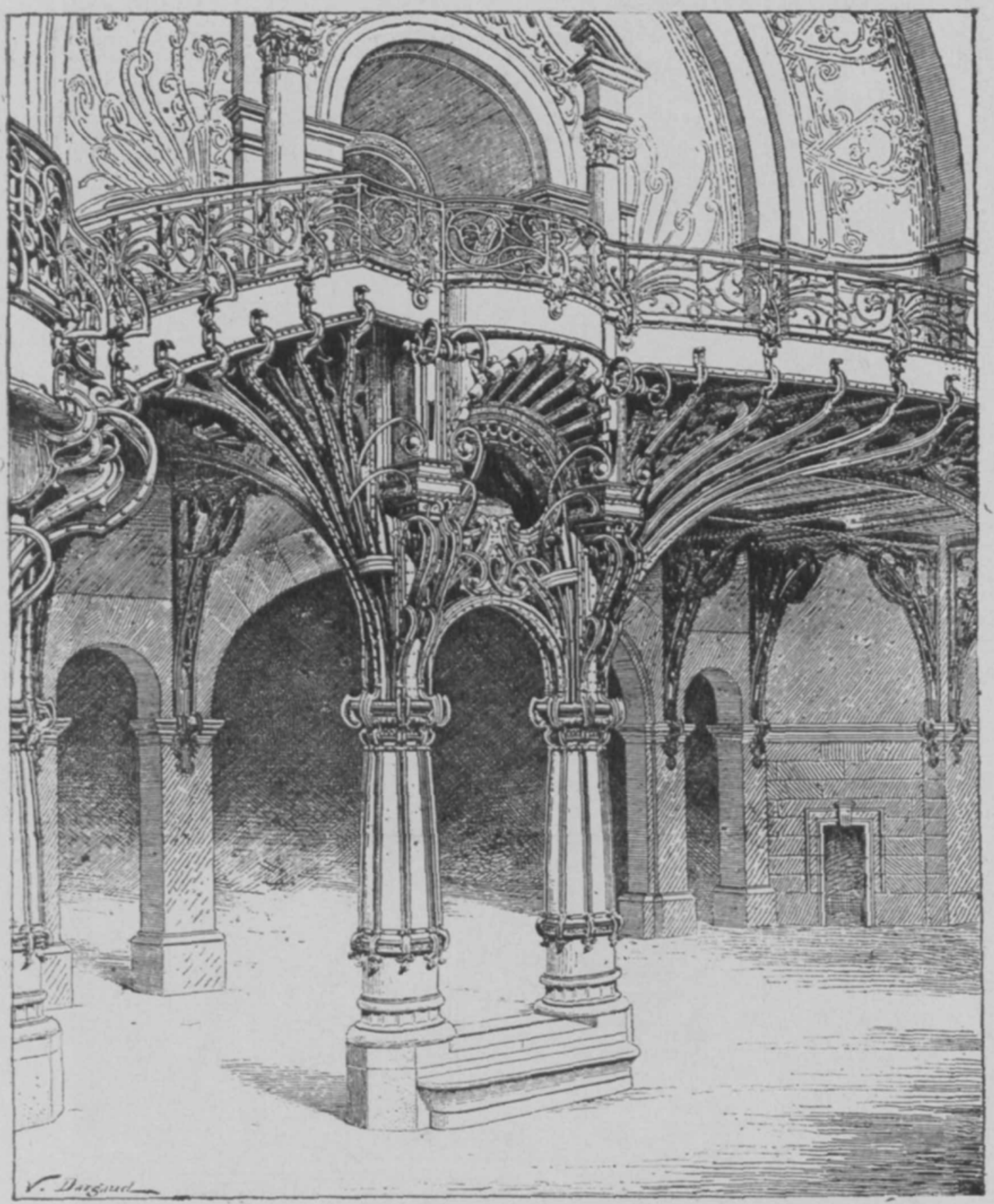

6. París. Palais des Beaux Arts. Veatíbulo.

(Cı. de La Construction Moderne, año VI, segunda serie.) 


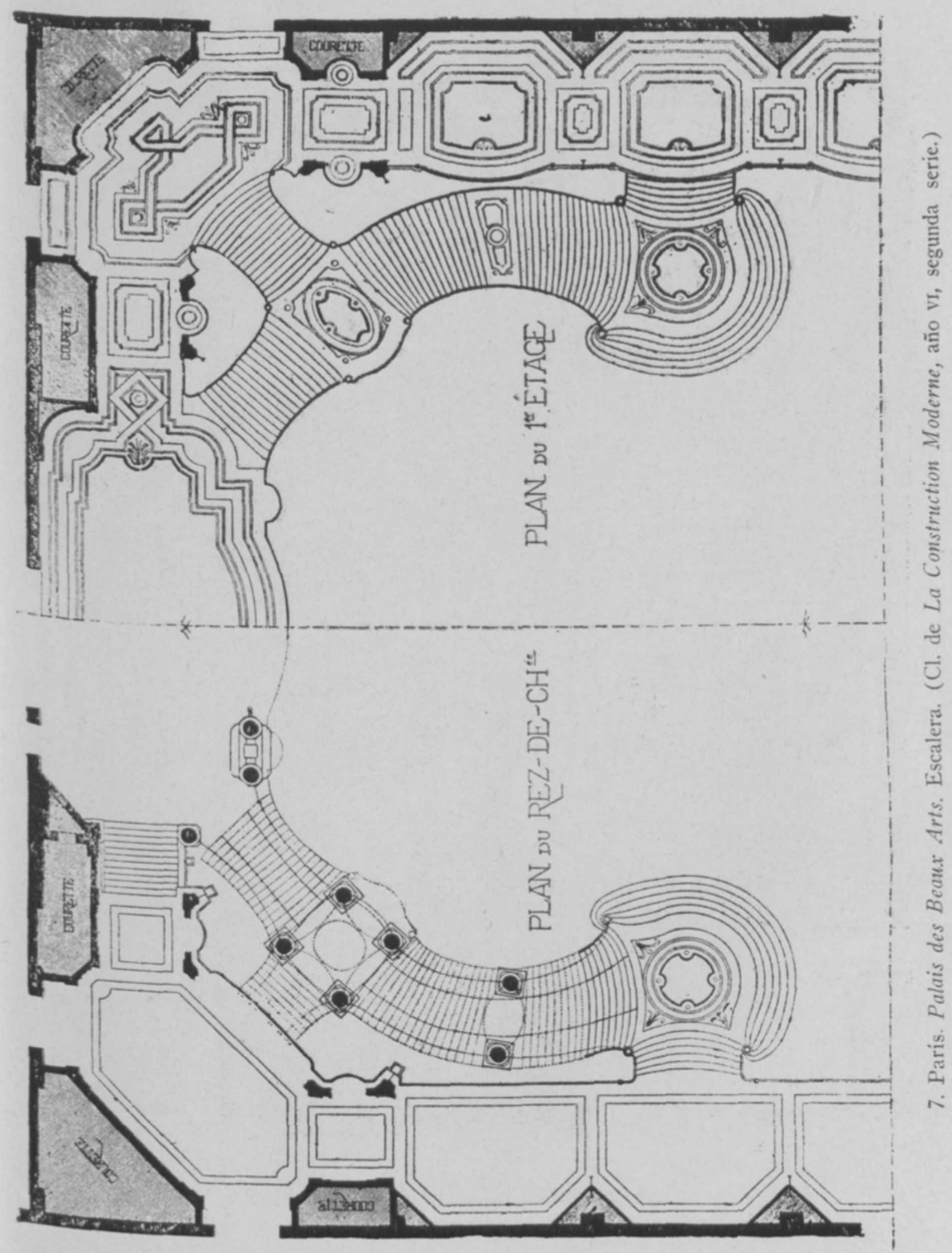




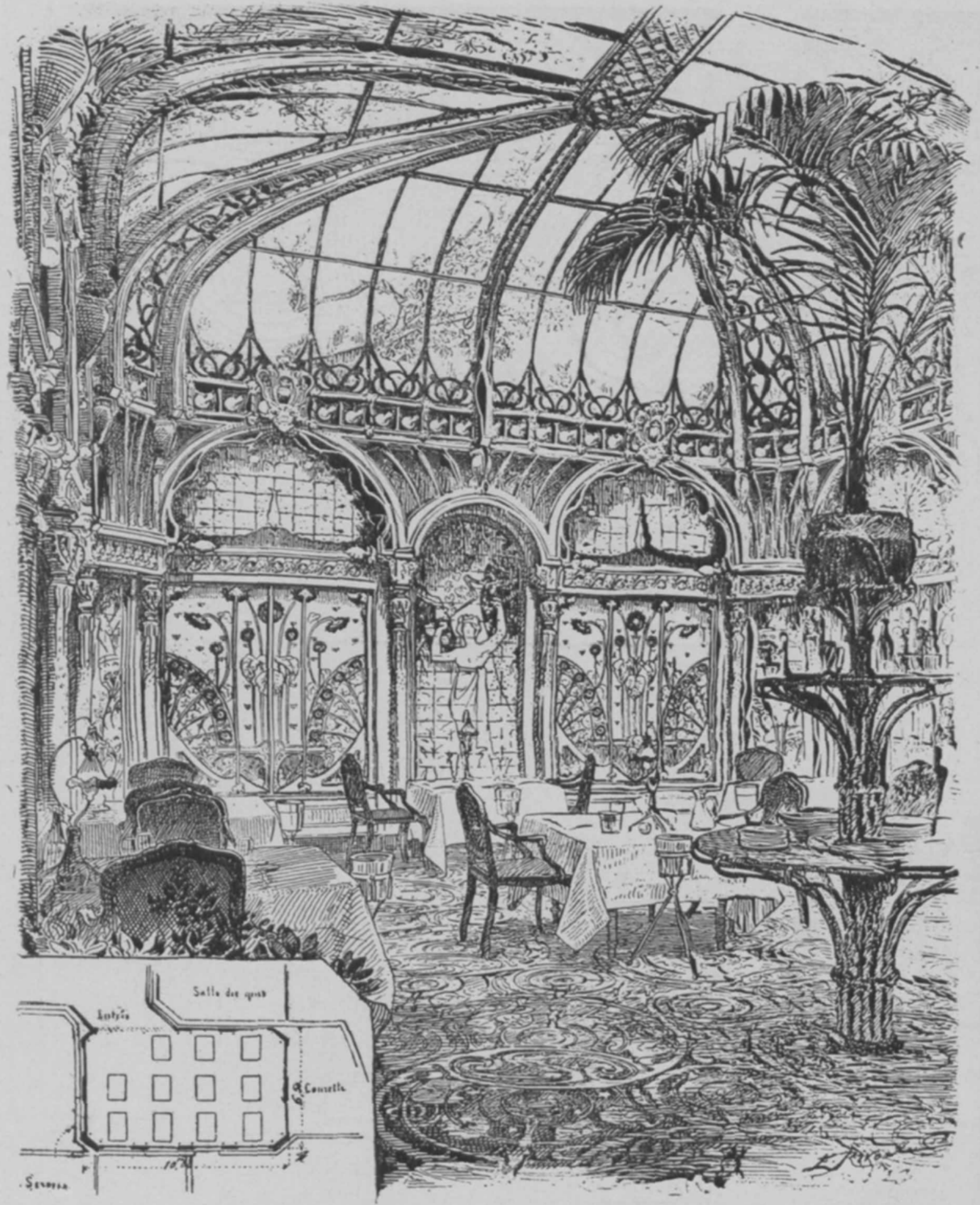

8. Restaurant de la rue Boccador.

(Cl. de La Construction Moderne, año III, segunda serie.) 


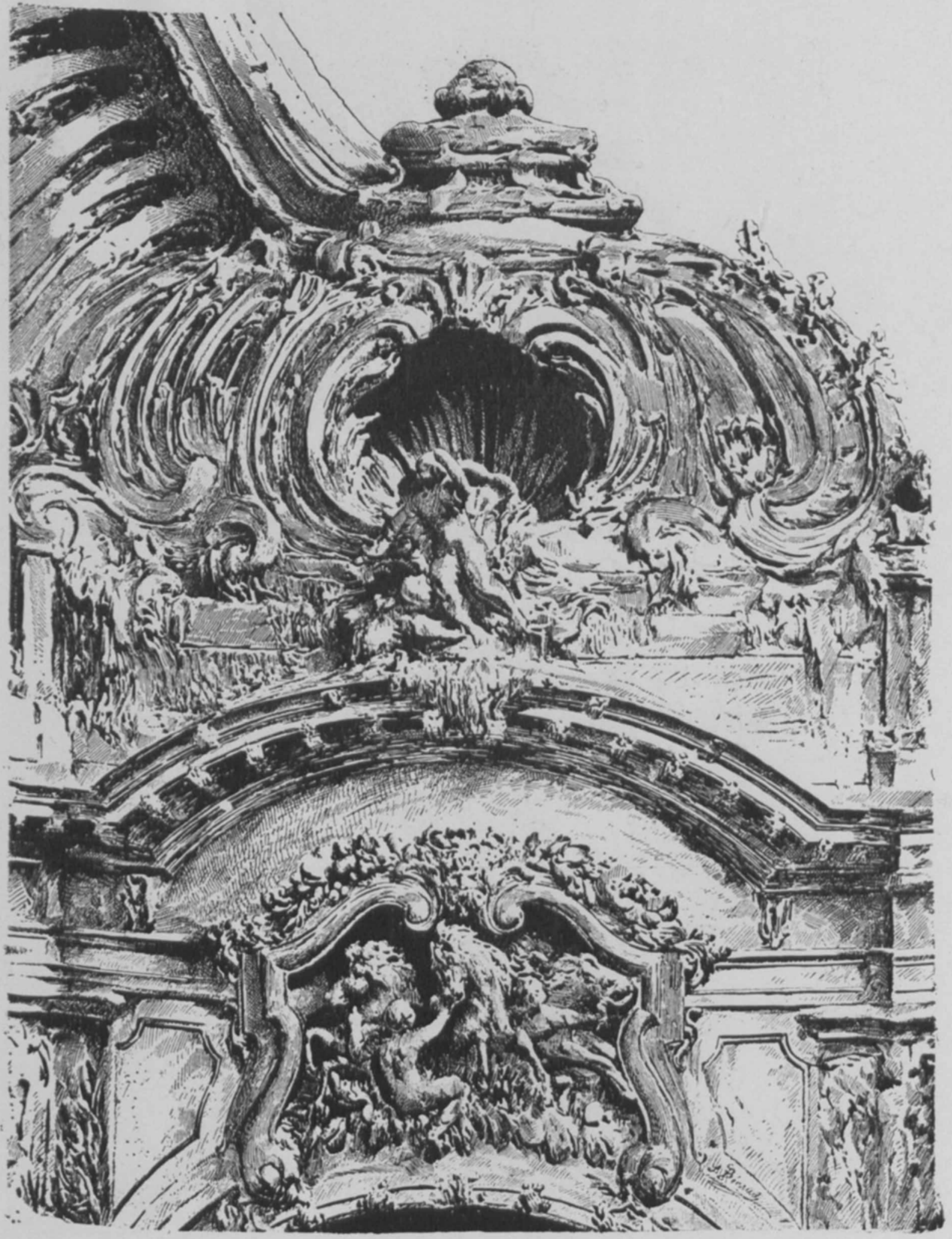

9. Paris. Le Chateau d'eau, Champs de Mars. Detalle. (Cl. de L'Architecture, año xII, $\mathrm{N}^{\circ} 28$. ) 


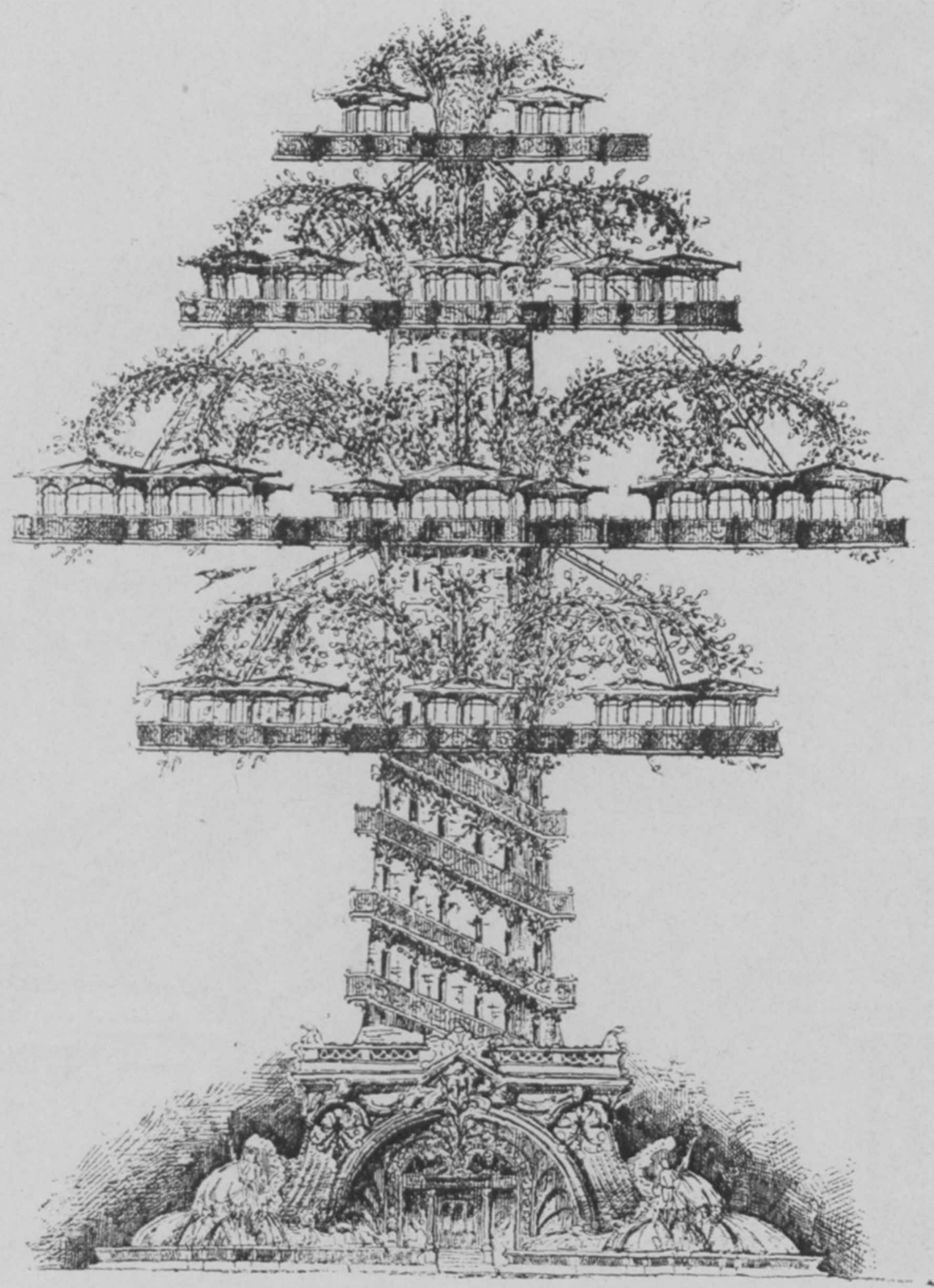

10. L'Orme de Scutari. (Cl. de L'Architecture, año xII, No 28.) 
DOI: http://dx.doi.org/10.22201/iie.18703062e.1957.26.2444

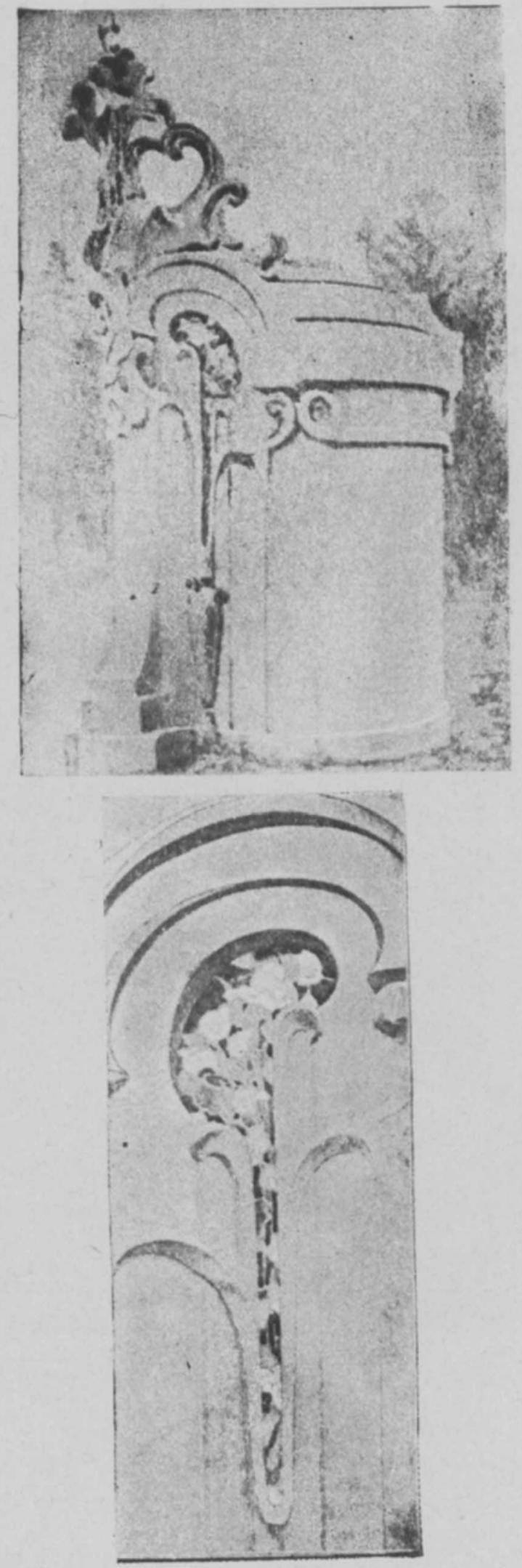

11. Nancy. Sepulcro. (Cl. de L'Architecture, año xv, $\mathrm{N}^{\circ} 9$. ) 


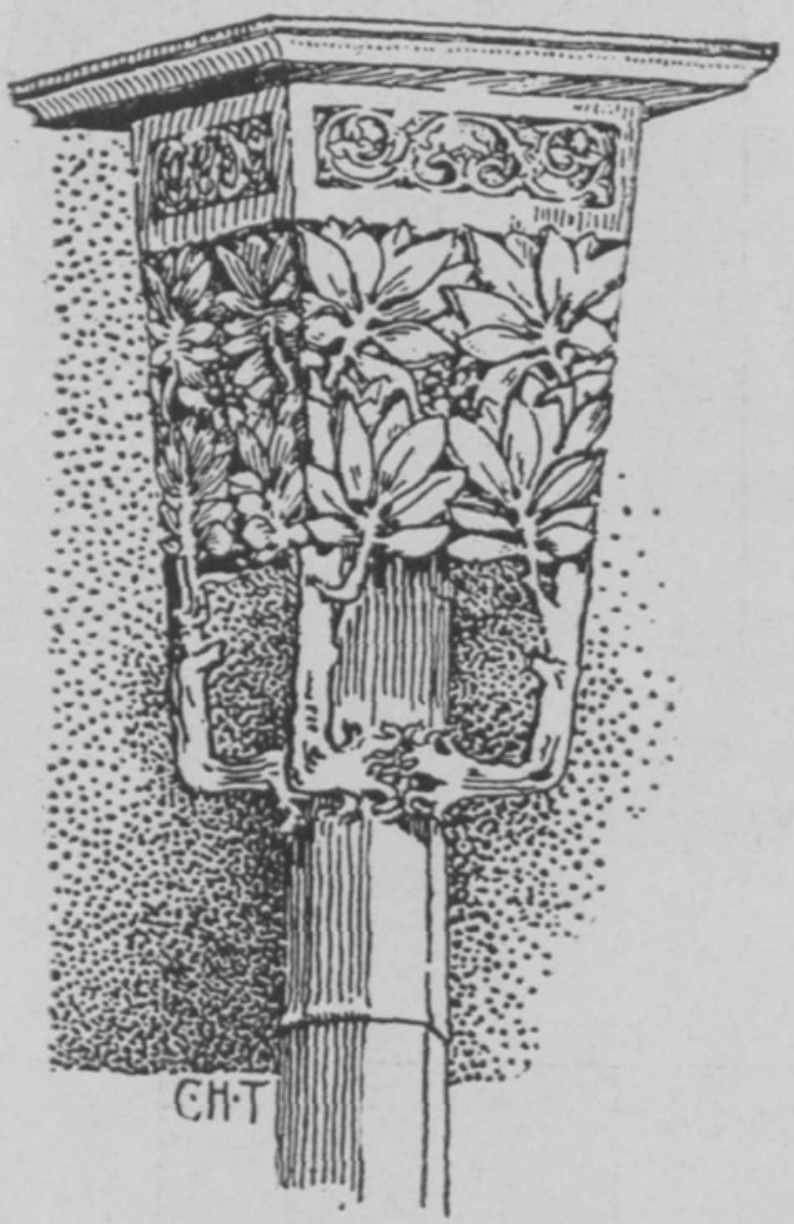

\section{Capitel Art-Nouveau.}

(C1. del libro: Sources of Art-Nouveau.) 


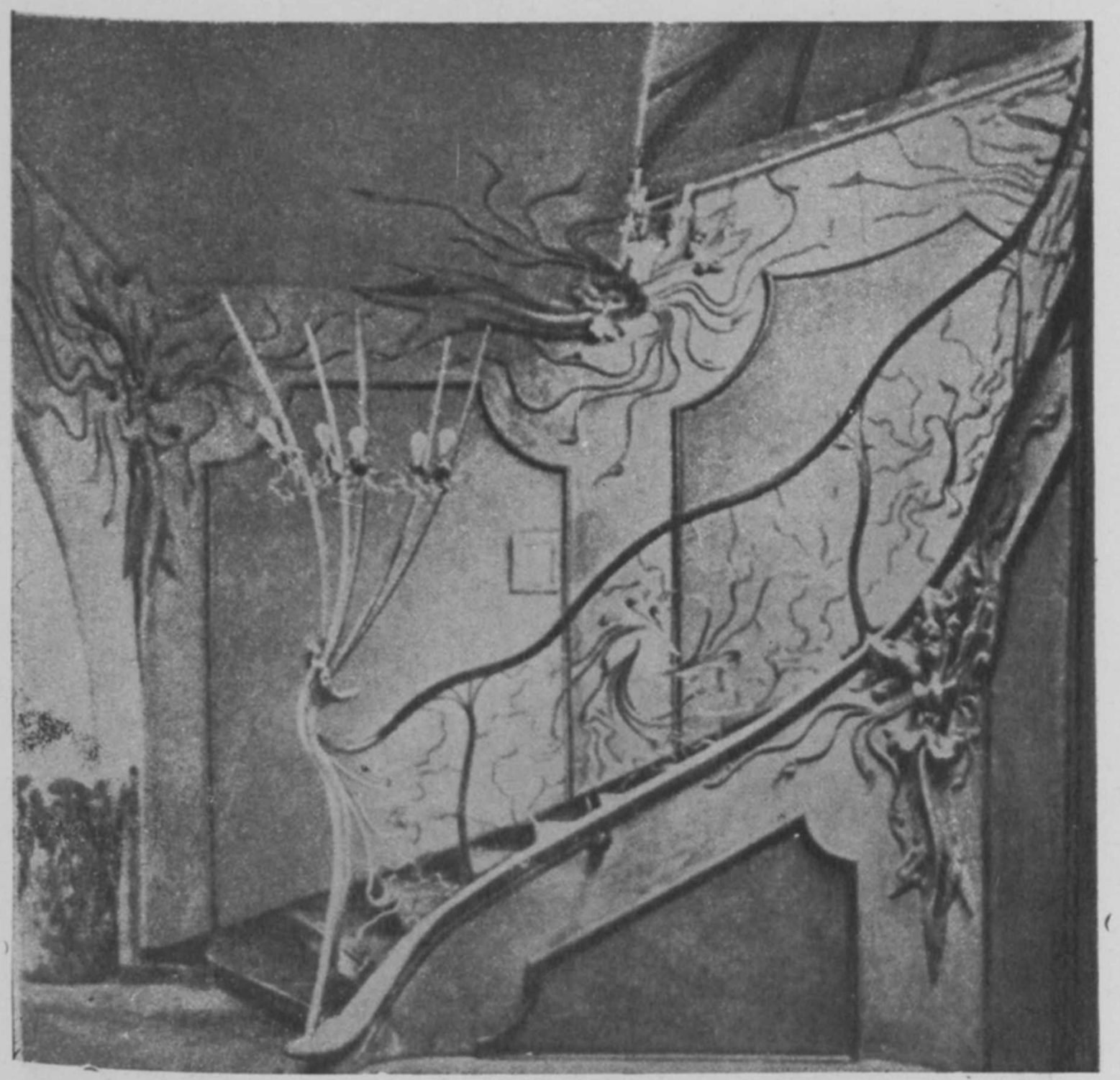

13. Munich. Atelier Elvira. (C1. del libro Sources of Art-Nouveau.) 


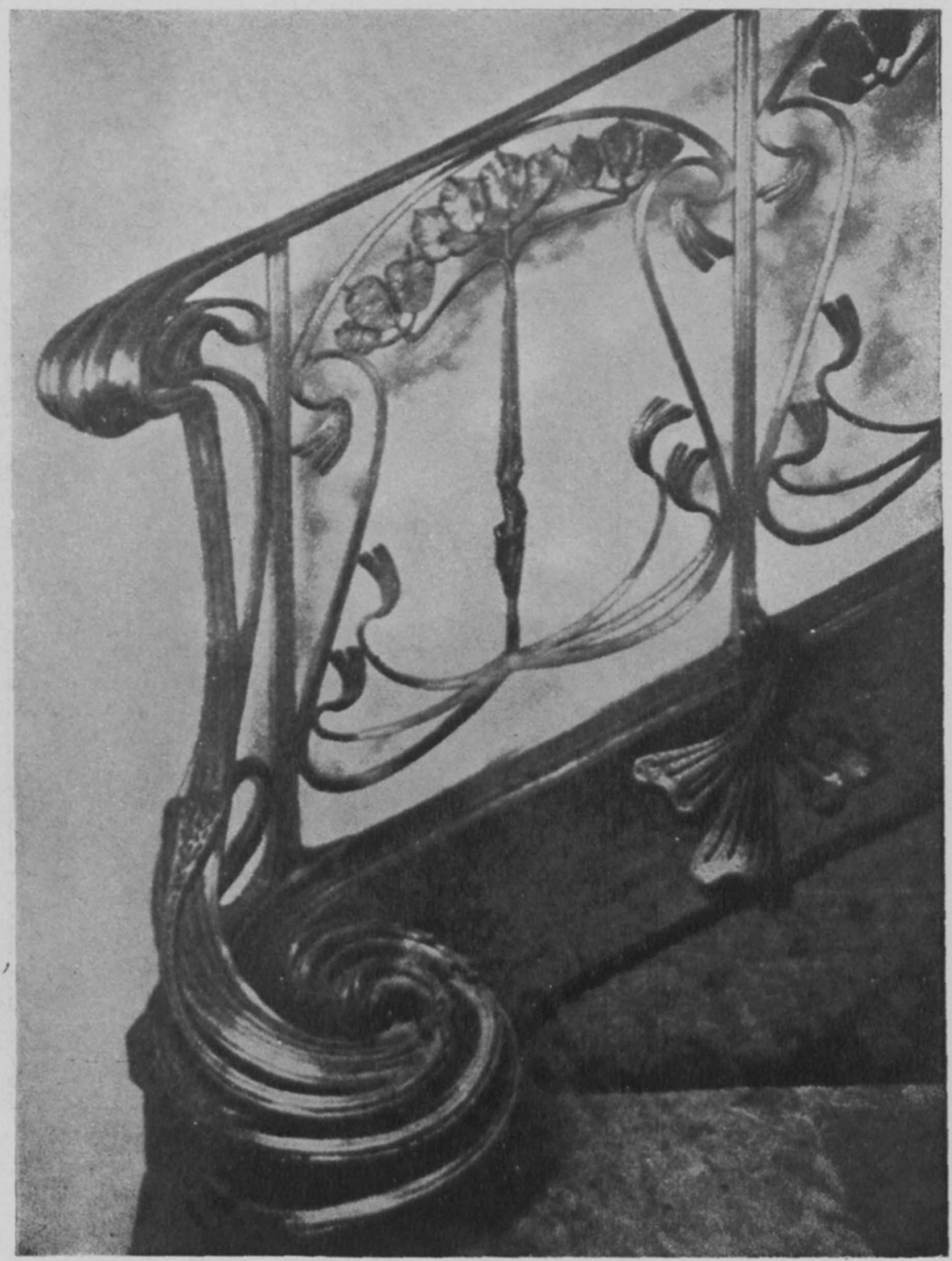

14. París. Museo de Artes Decorativas. Escalera. (Cl. del libro Sources of Art-Nonveau.) 


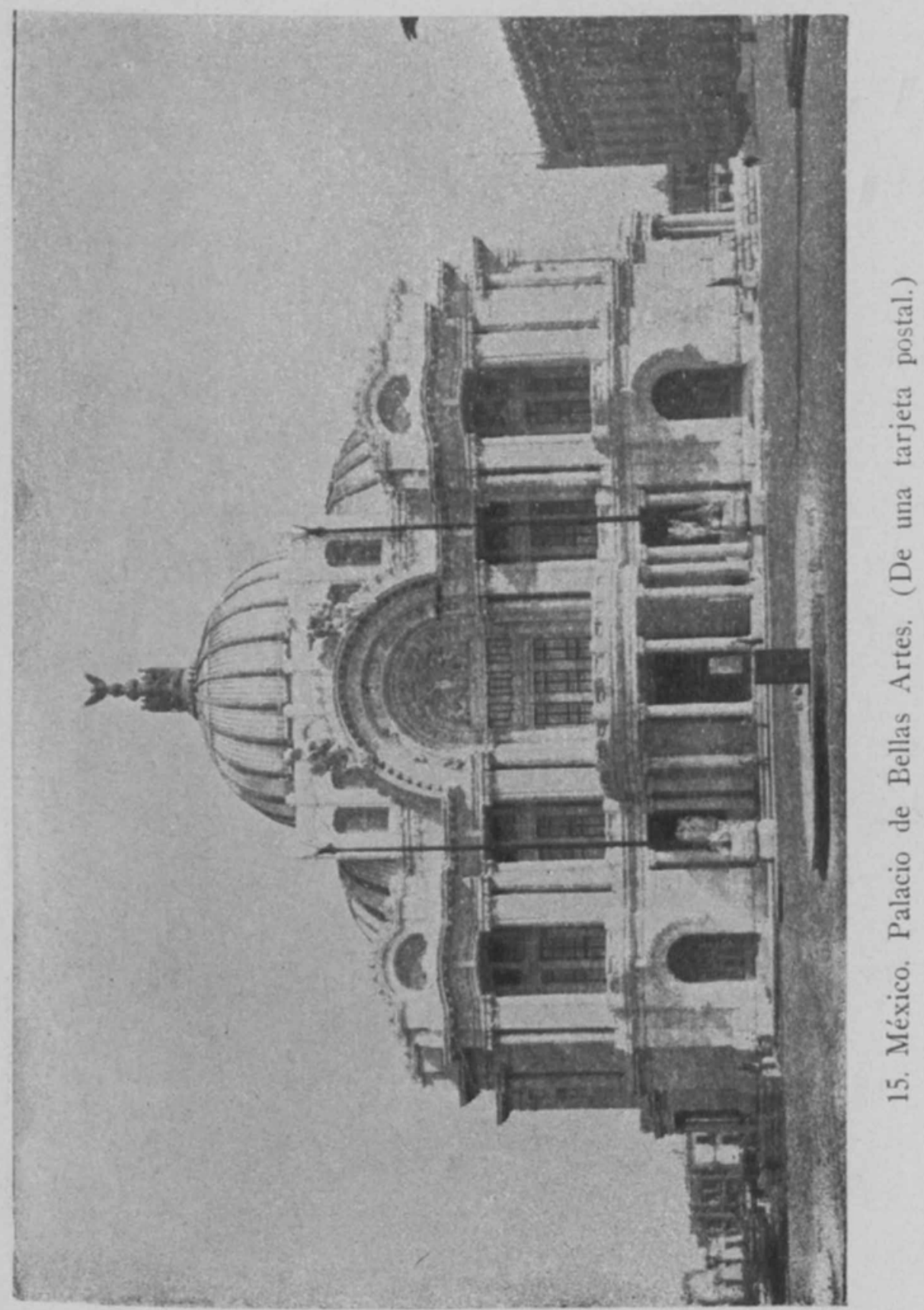




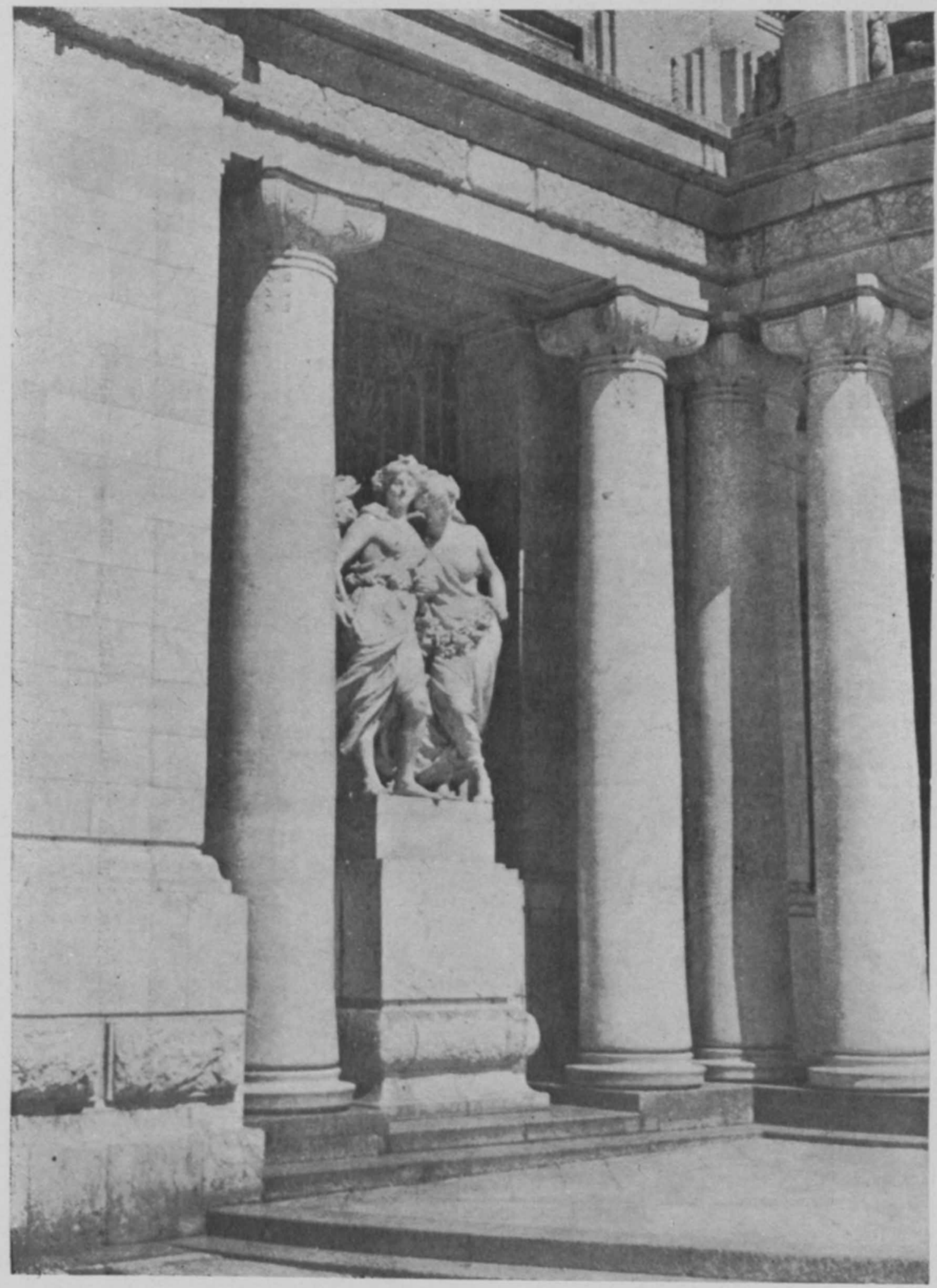

16. México. Palacio de Bellas Artes. Columnas. (Foto F. de la Maza.) 


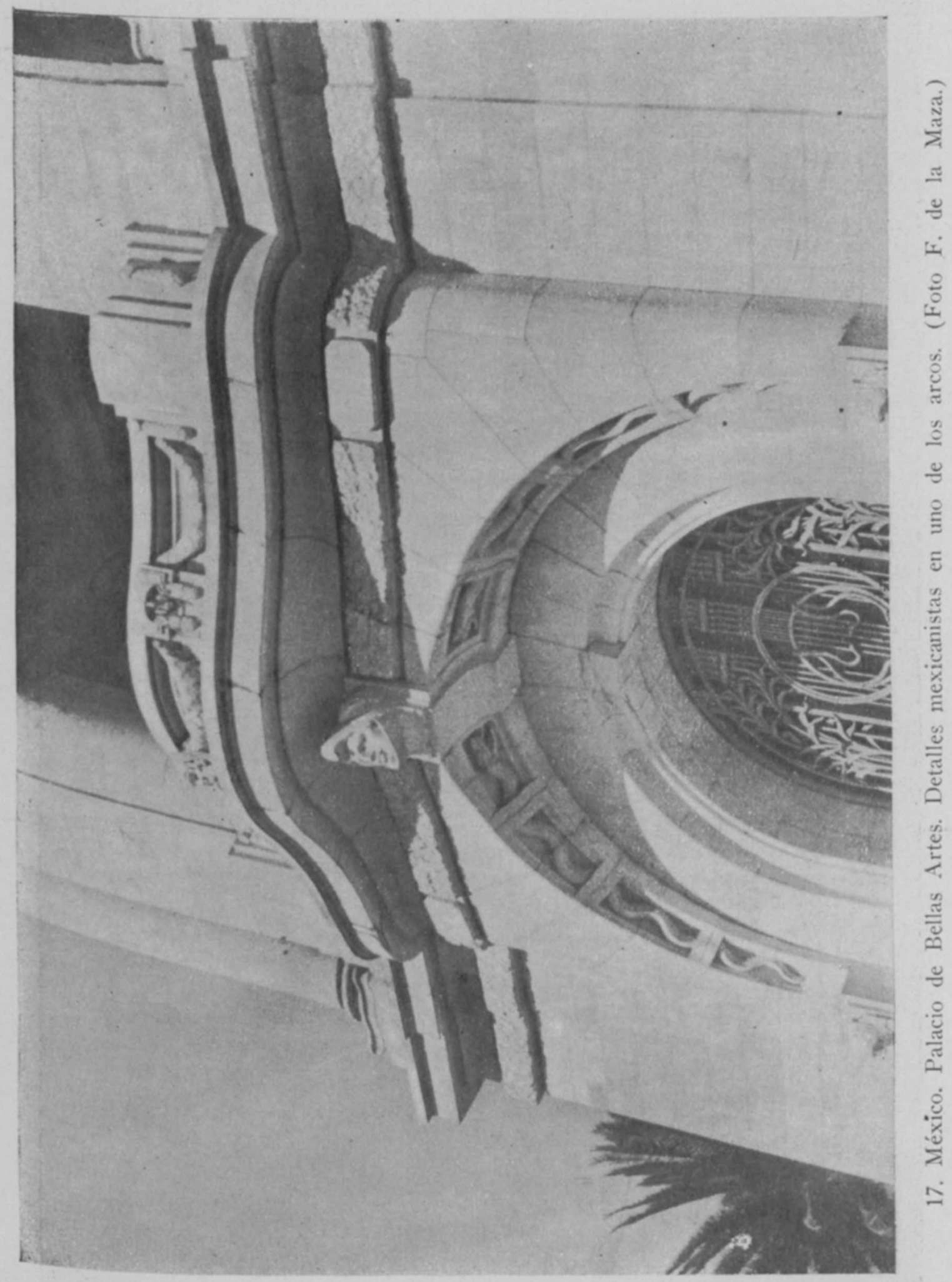




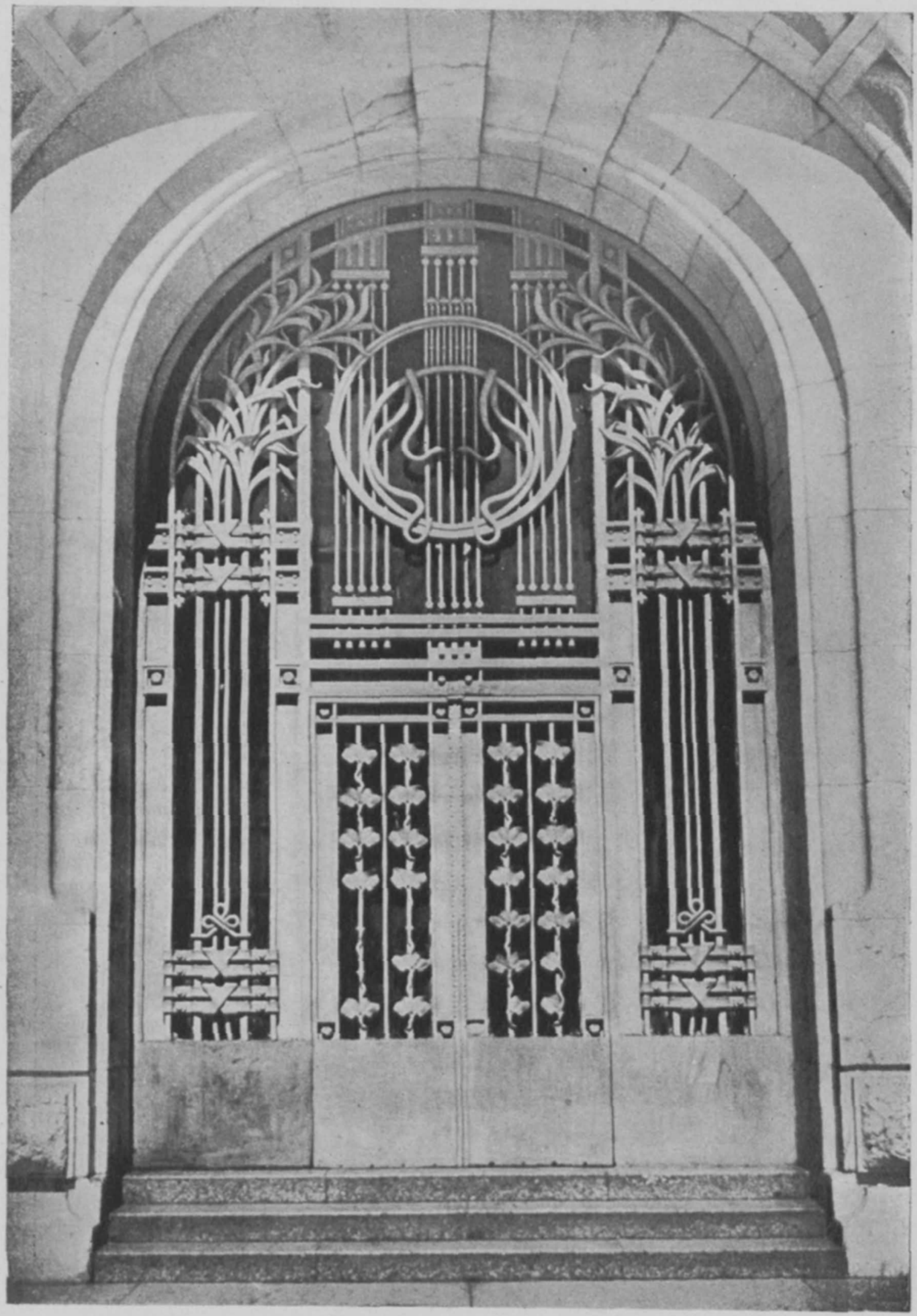

18. México. Palacio de Bellas Artes, Reja. (Foto F. de la Maza.) 

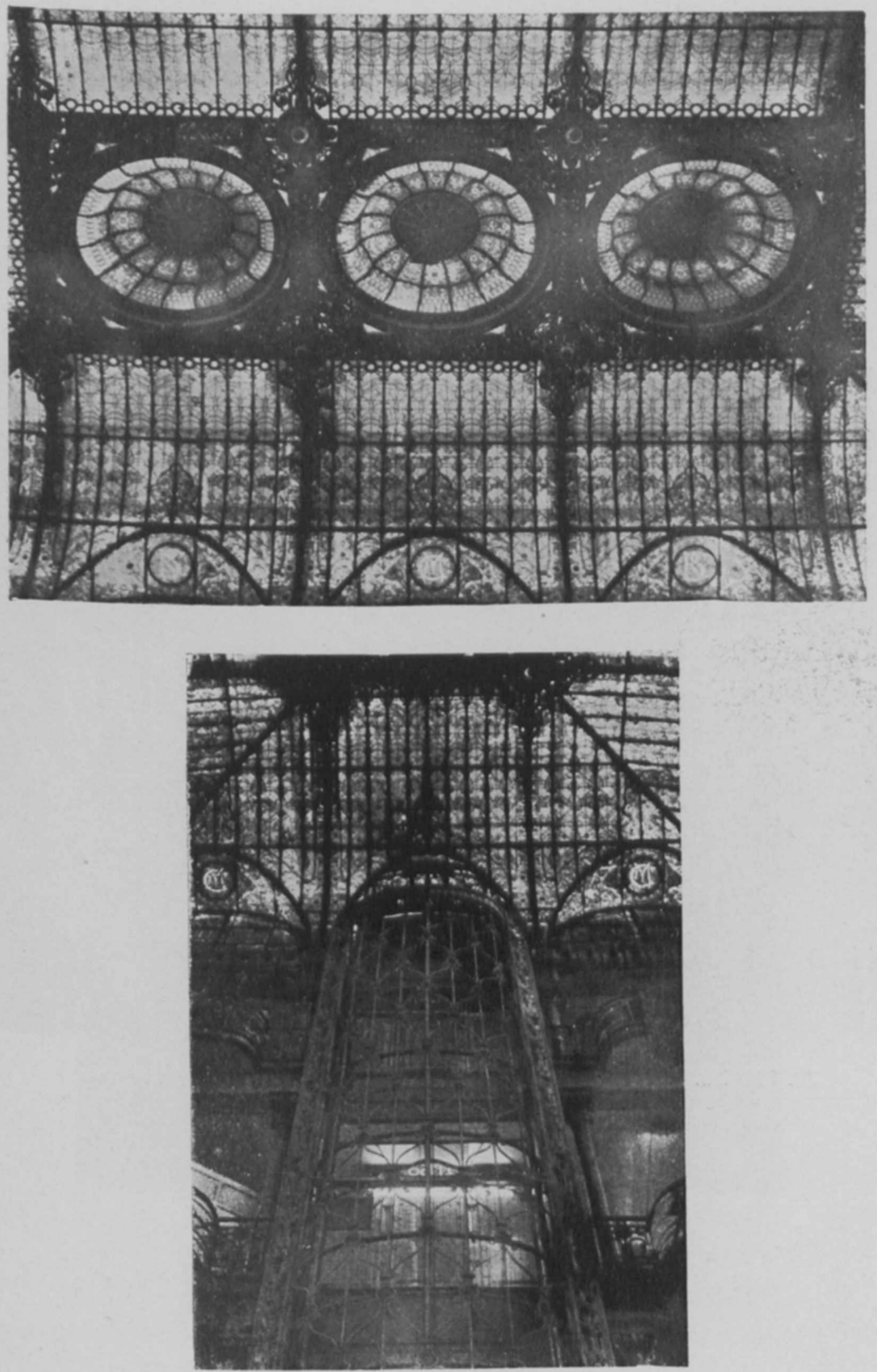

19. México. "El Centro Mercantil". Plafond y ascensor. (Fotos F. de la Maza.) 
DOI: http://dx.doi.org/10.22201/iie.18703062e.1957.26.2444

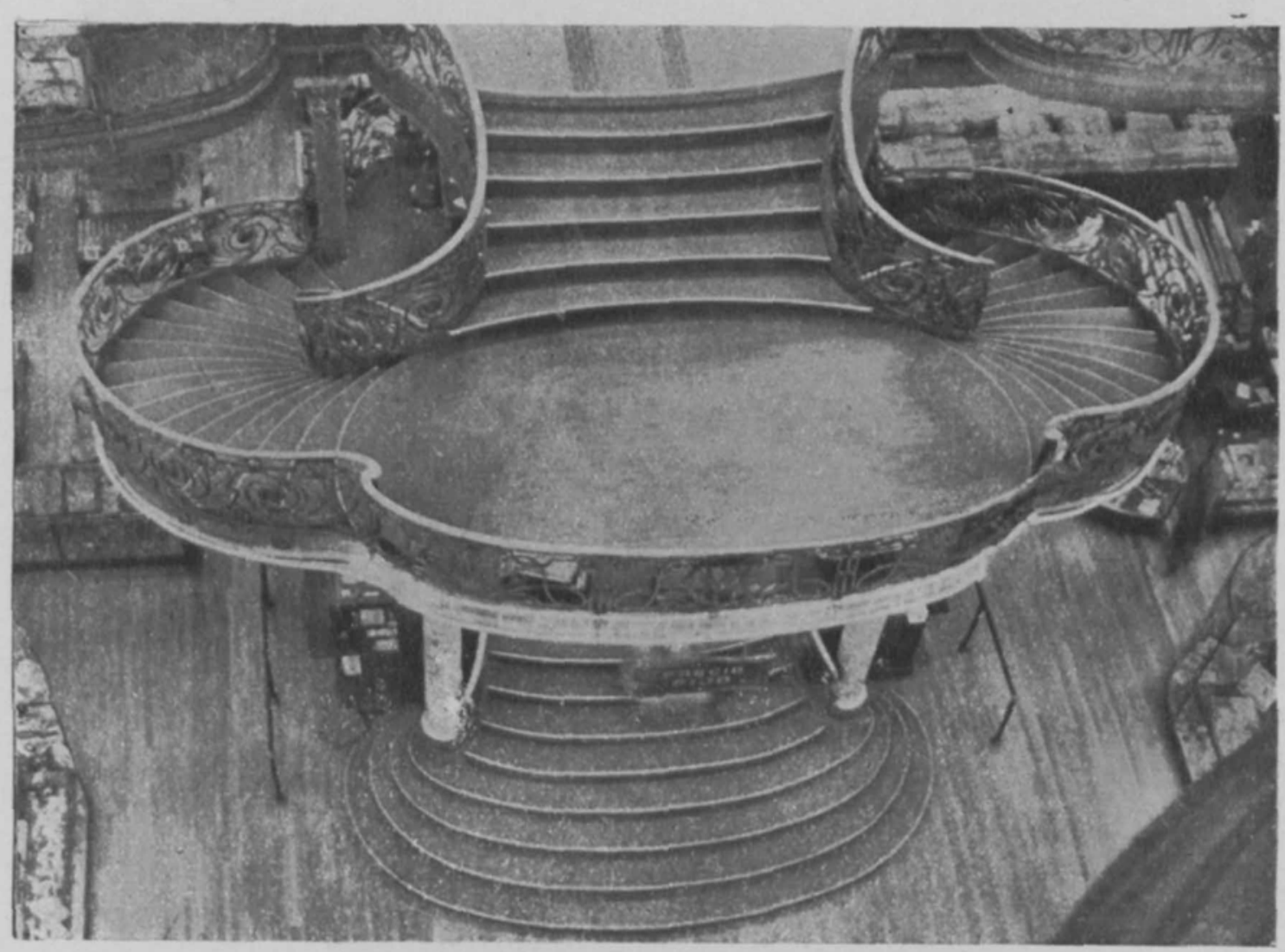

20. México. "El Centro Mercantil". Escalera. (Foto F. de la Maza.) 
DOI: http://dx.doi.org/10.22201/iie.18703062e.1957.26.2444

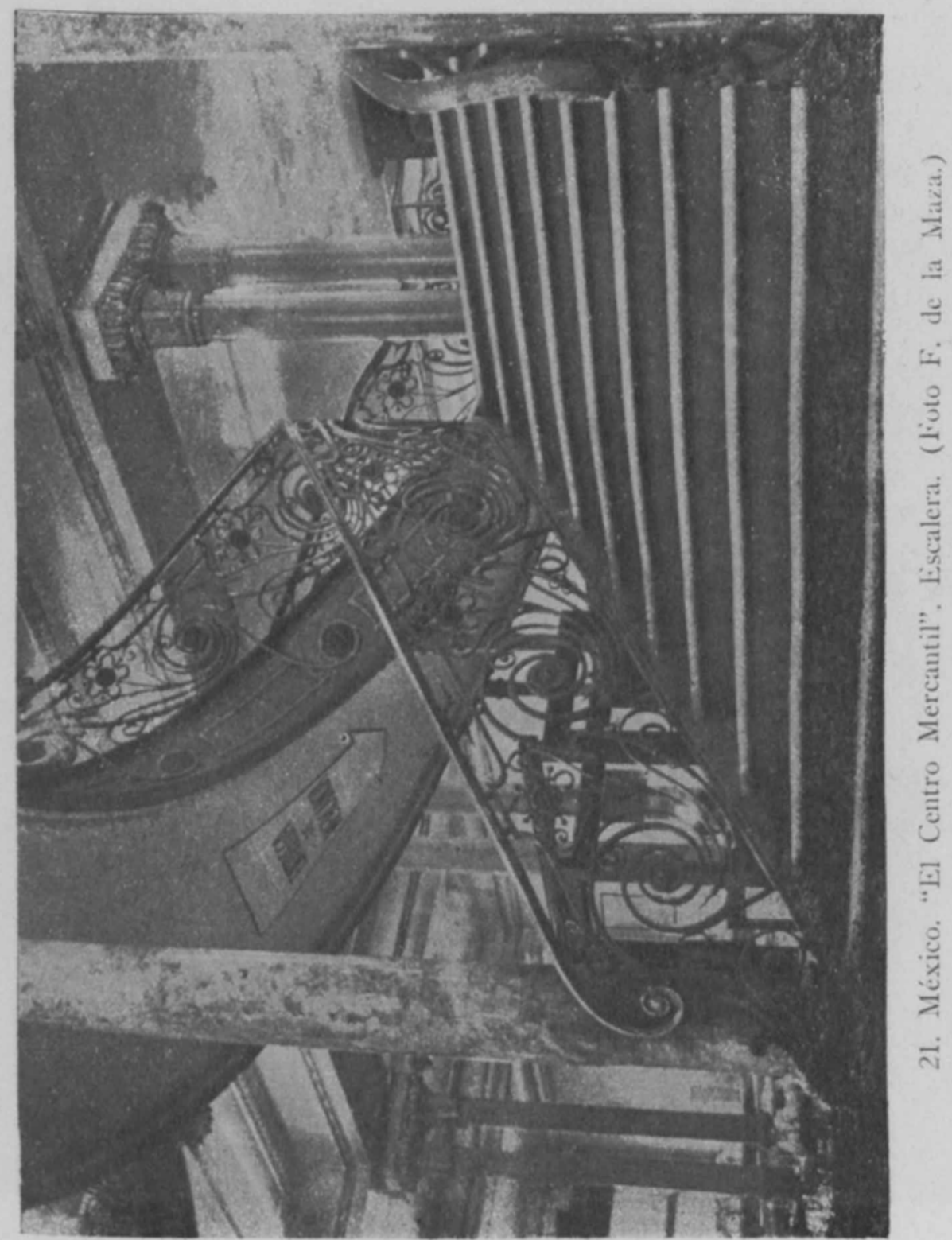




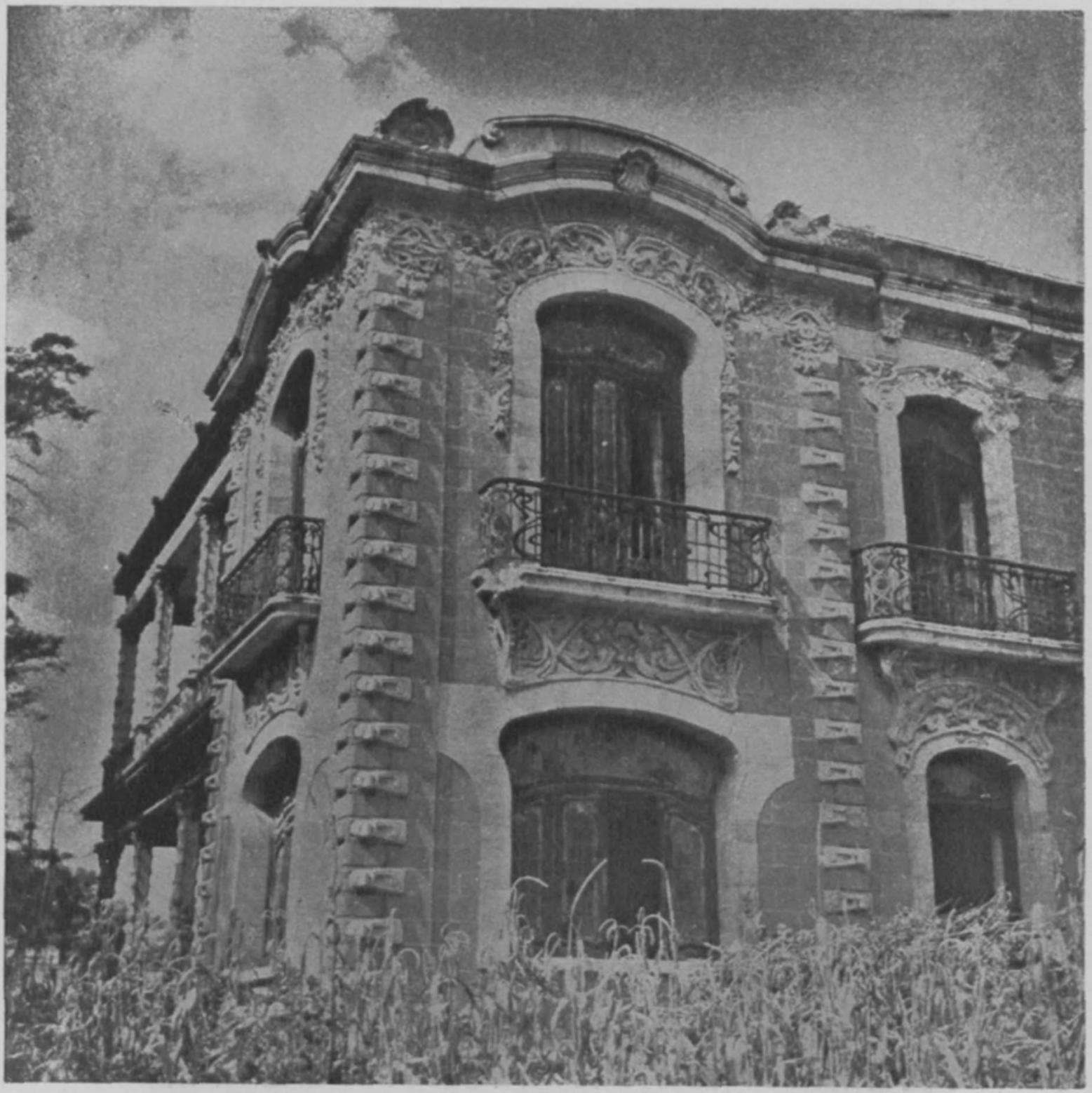

22. México. Casa en la calzada Pedro Antonio de los Santos. (Foto V. M. Villegas.) 
DOI: http://dx.doi.org/10.22201/iie.18703062e.1957.26.2444
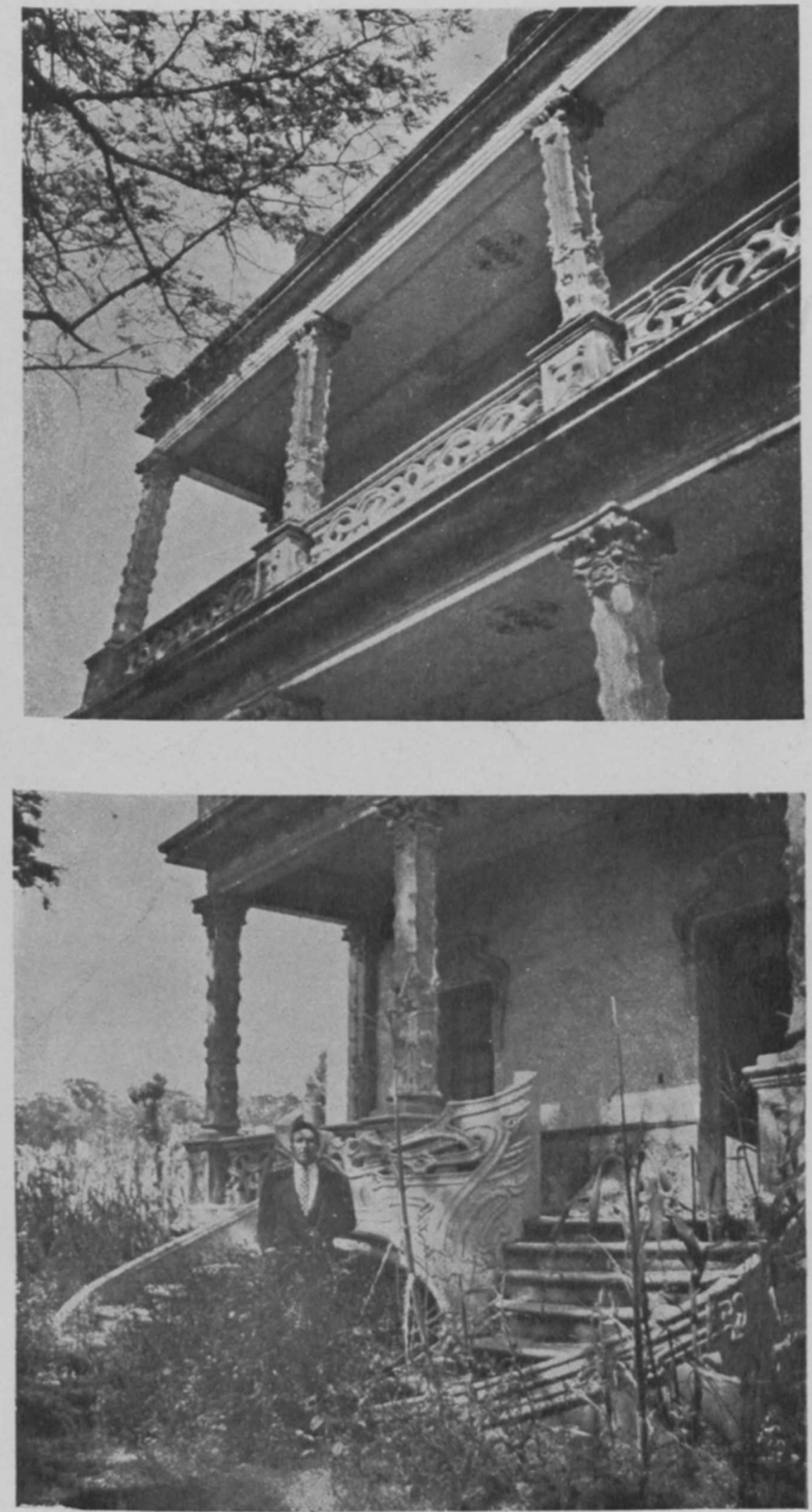

23. Terraza y escalera de la casa anterior.

(Foto V. M. Villegas.) 


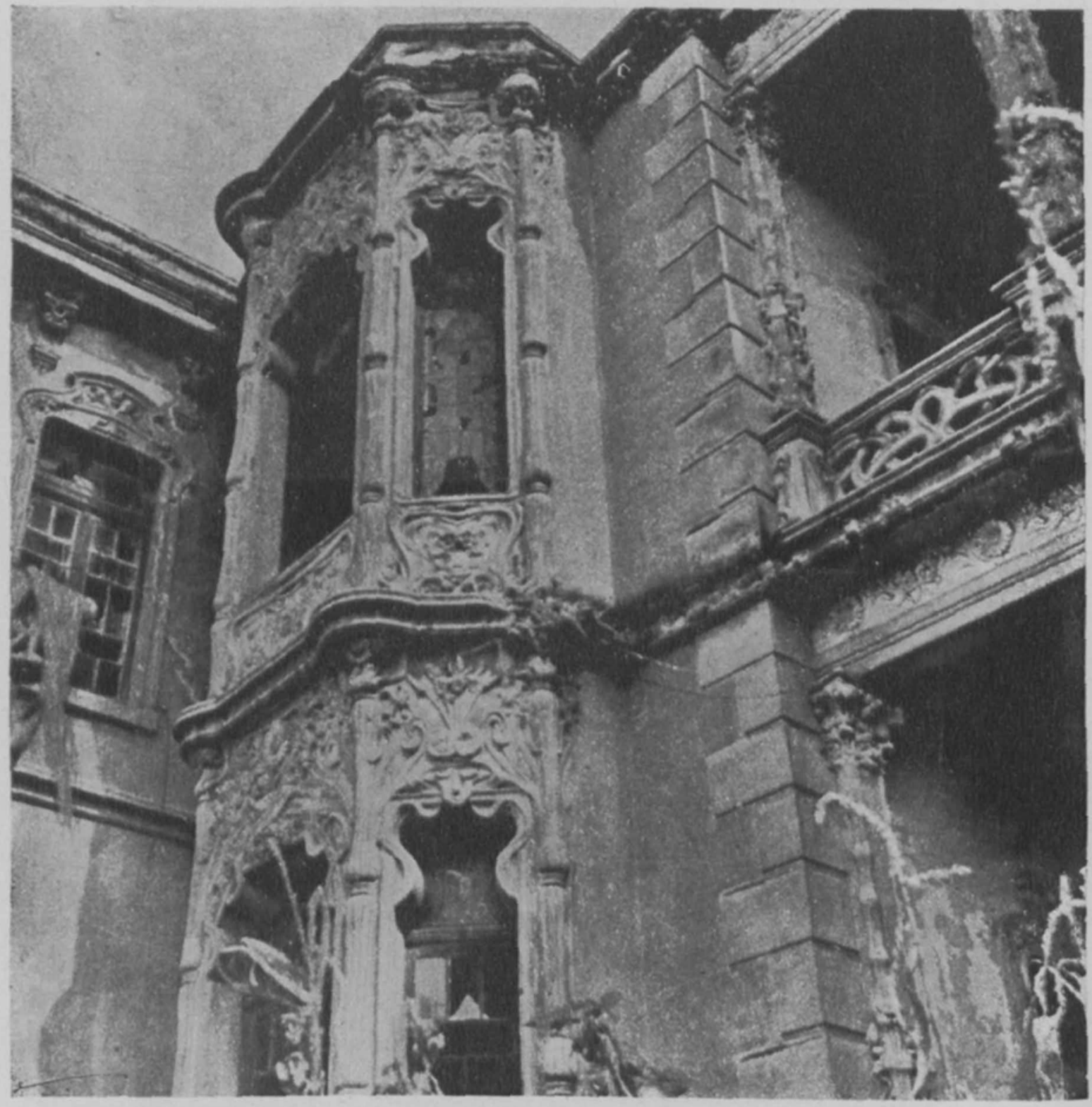

24. Mirador de la casa anterior. (Foto V. M. Villegas.) 
DOI: http://dx.doi.org/10.22201/iie.18703062e.1957.26.2444

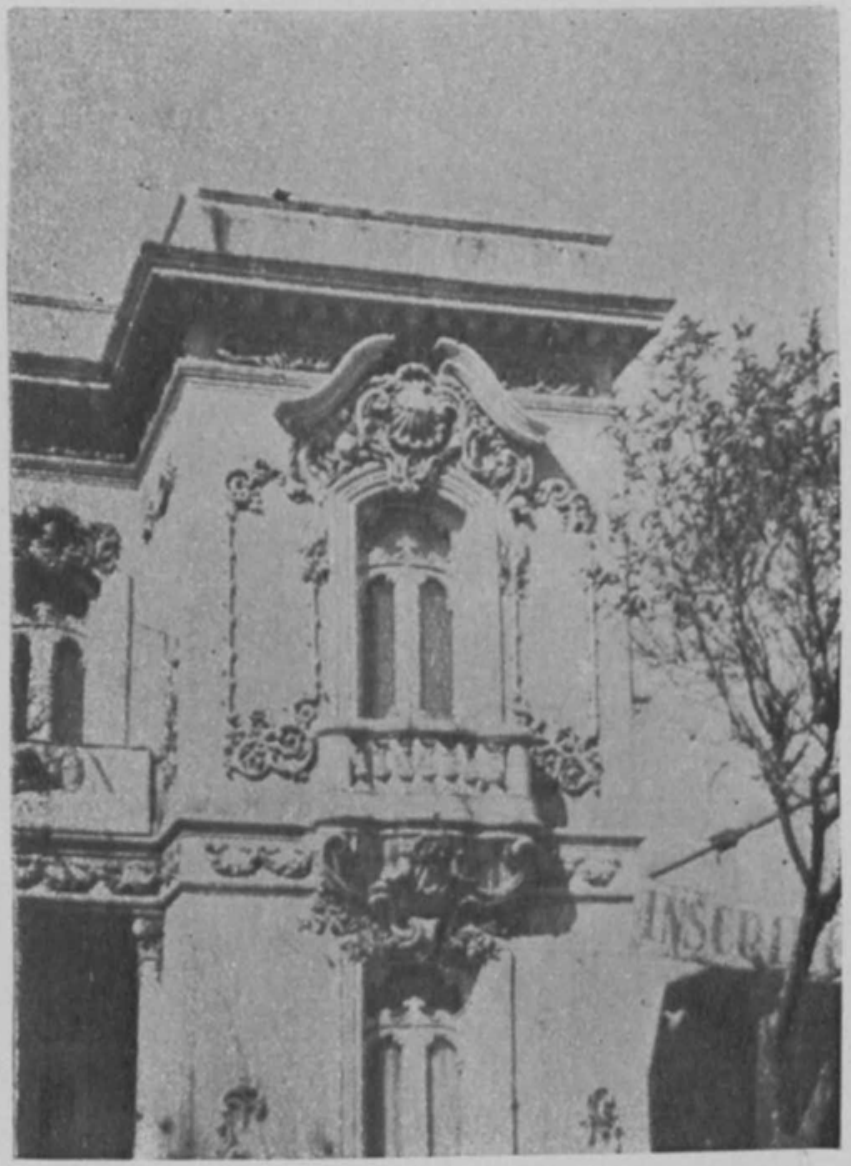

25. México. Casa en la calle de Londres. Detalle. (Foto F. de la Maza.) 
DOI: http://dx.doi.org/10.22201/iie.18703062e.1957.26.2444

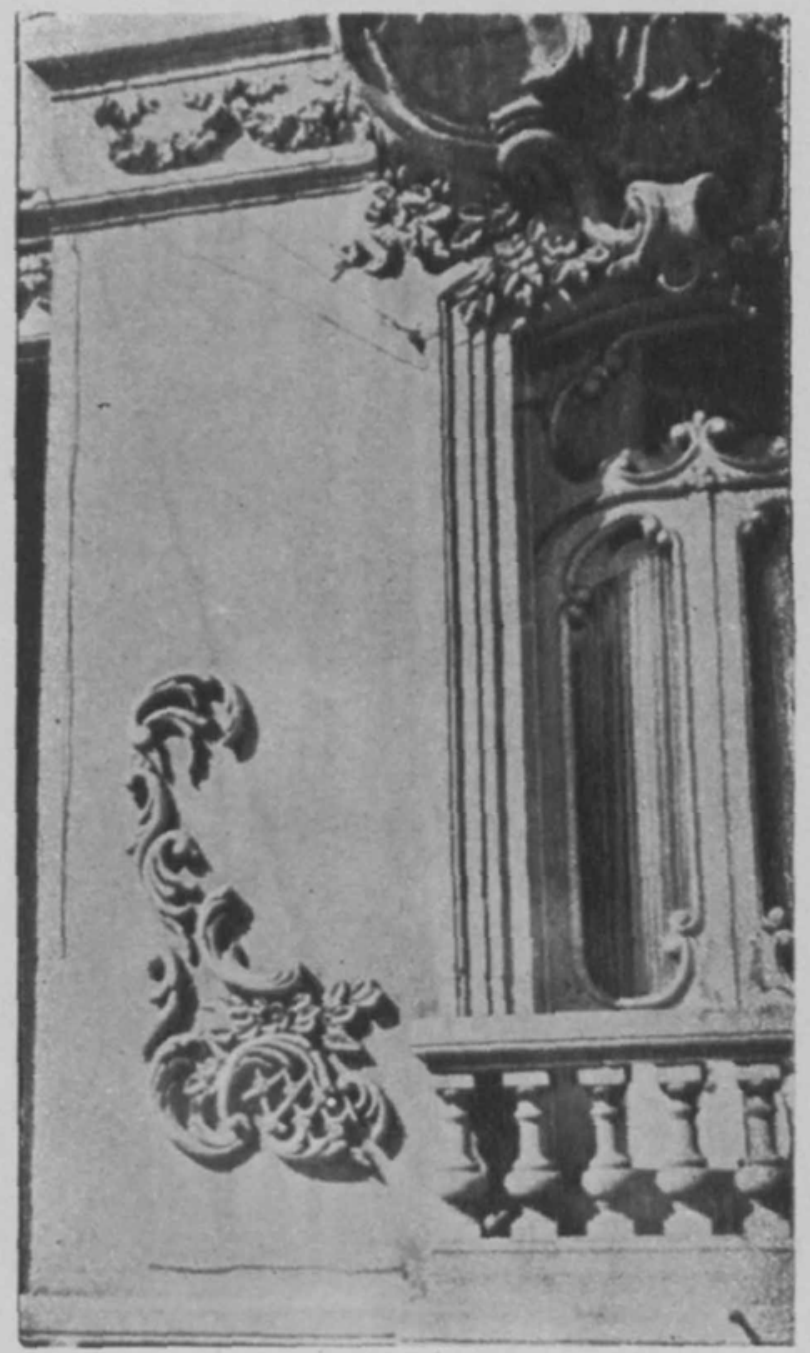

26: Detalle de la anterior.

(Foto F. de la Maza.) 
DOI: http://dx.doi.org/10.22201/iie.18703062e.1957.26.2444

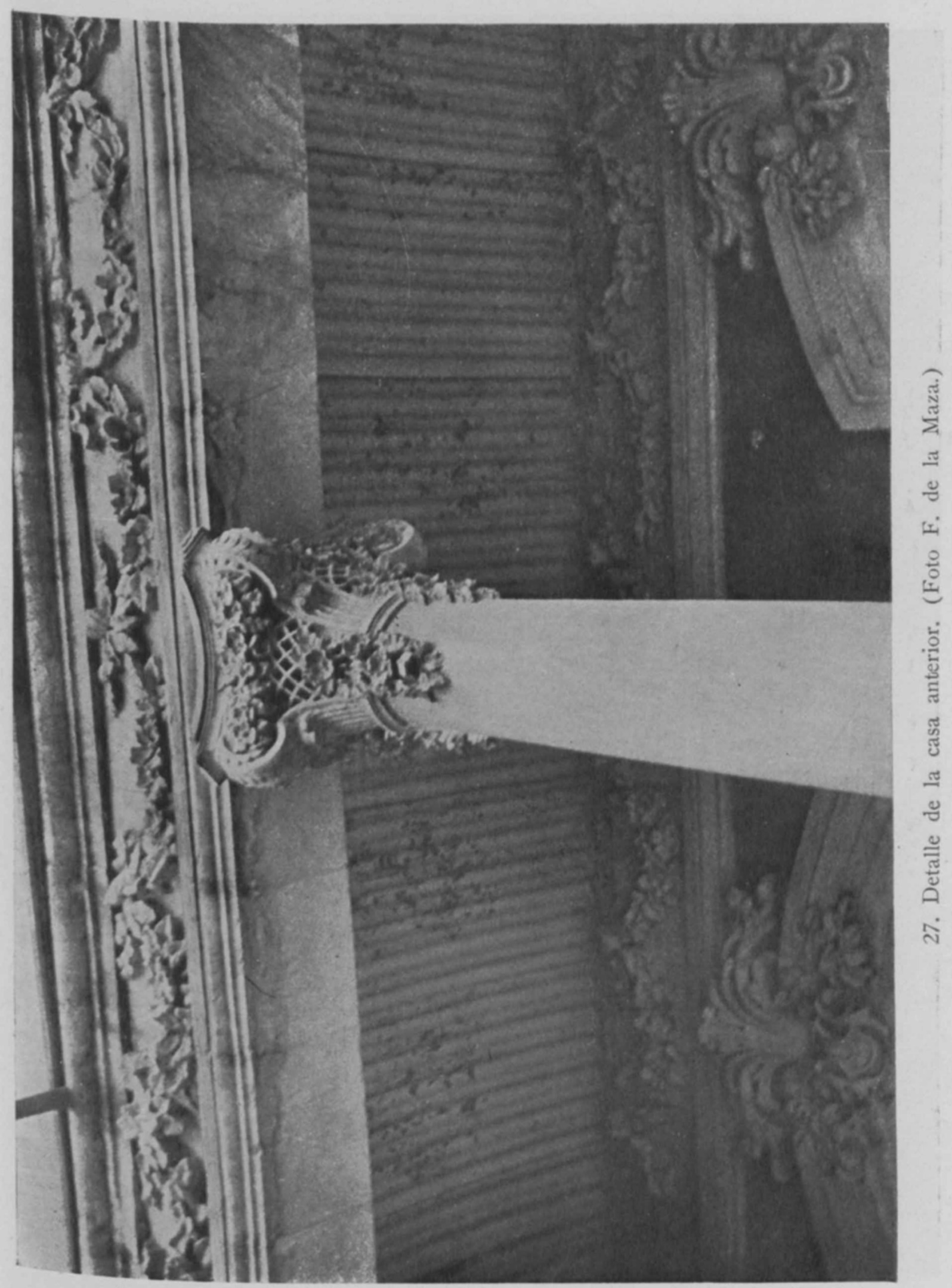




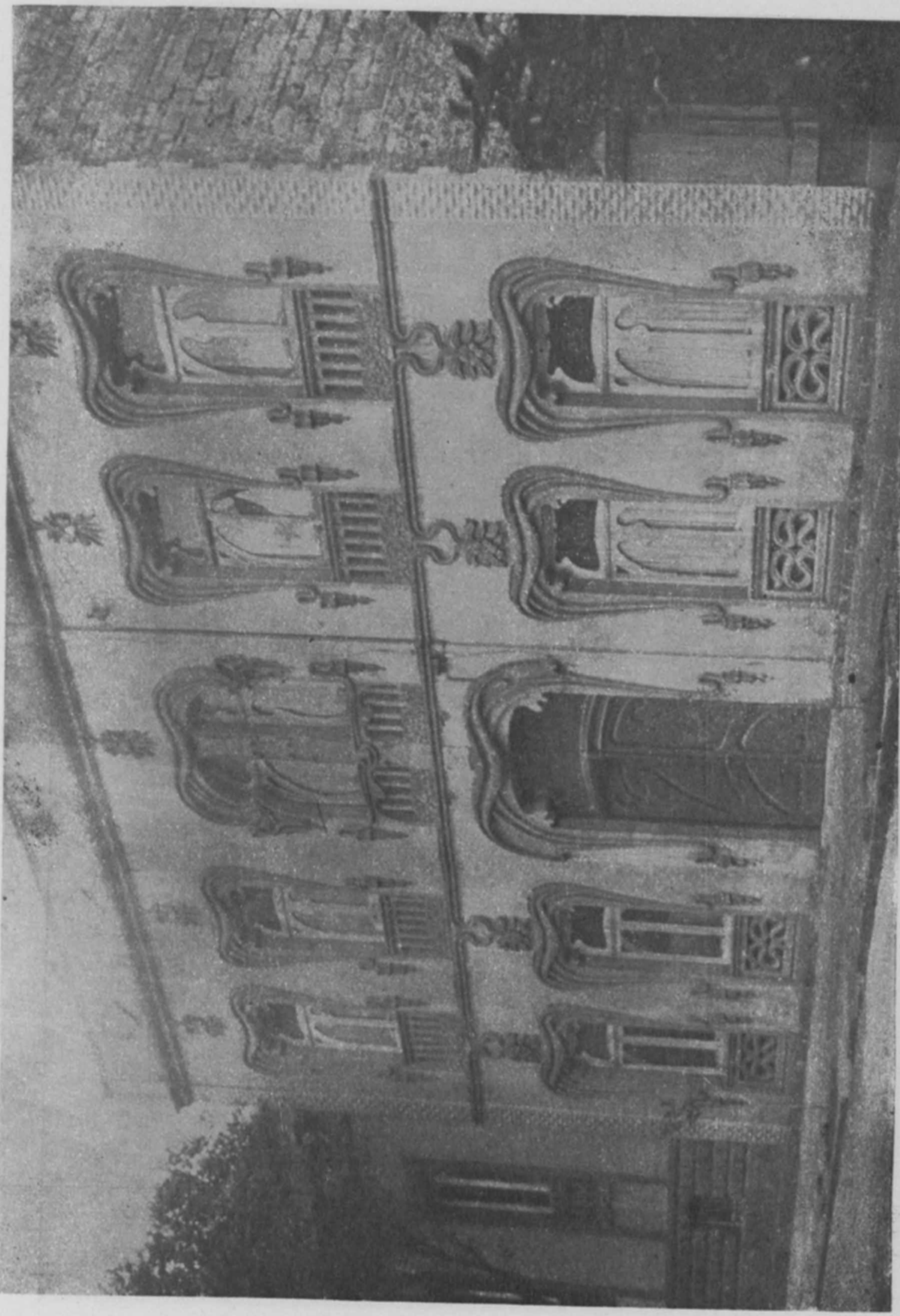

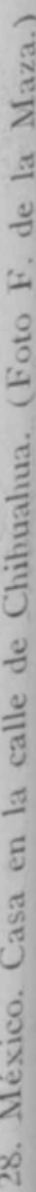



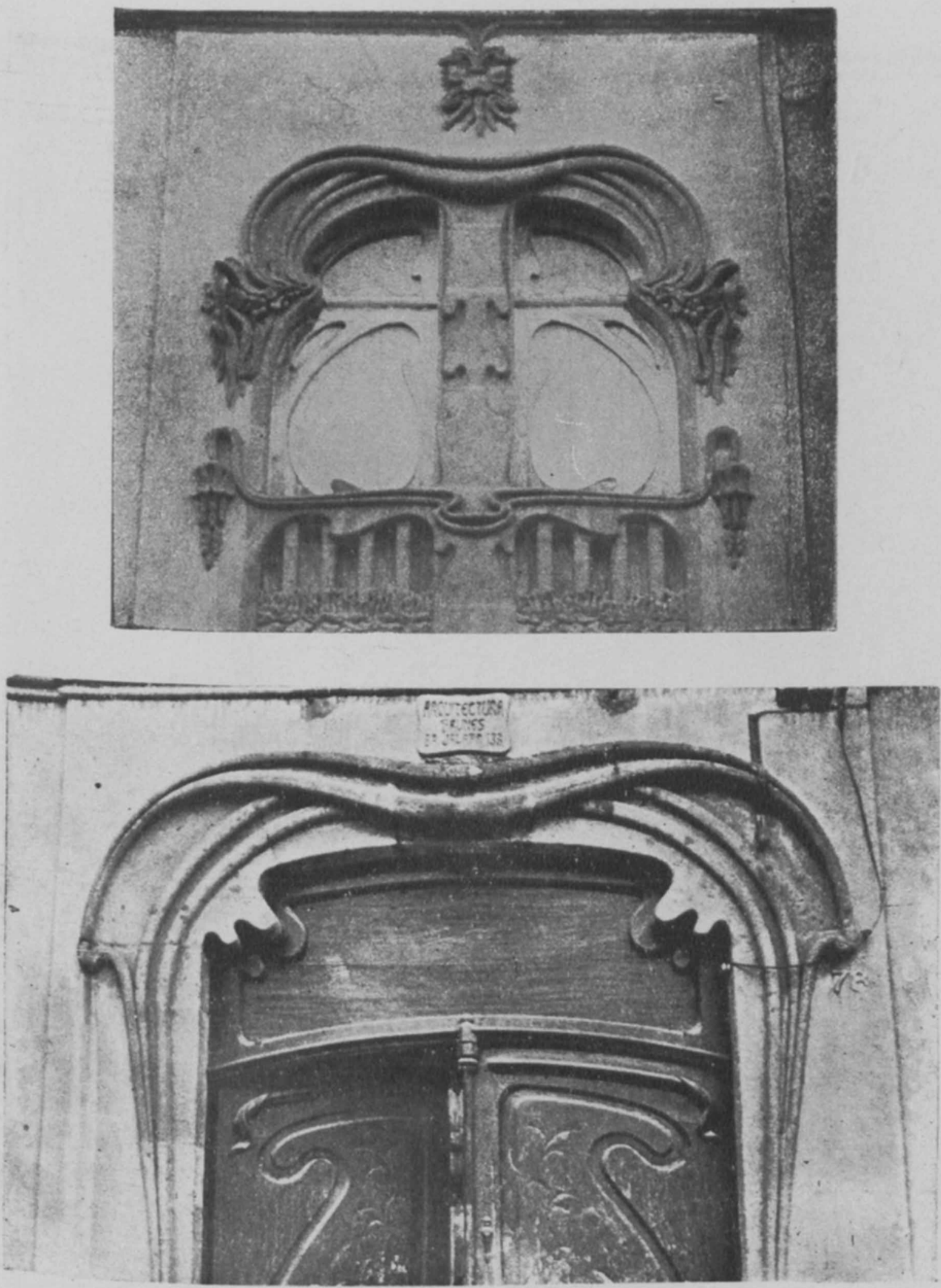

29. México. Casa en la calle de Chilumalua. Detallics. (Foto F. de la Maza.) 
DOI: http://dx.doi.org/10.22201/iie.18703062e.1957.26.2444

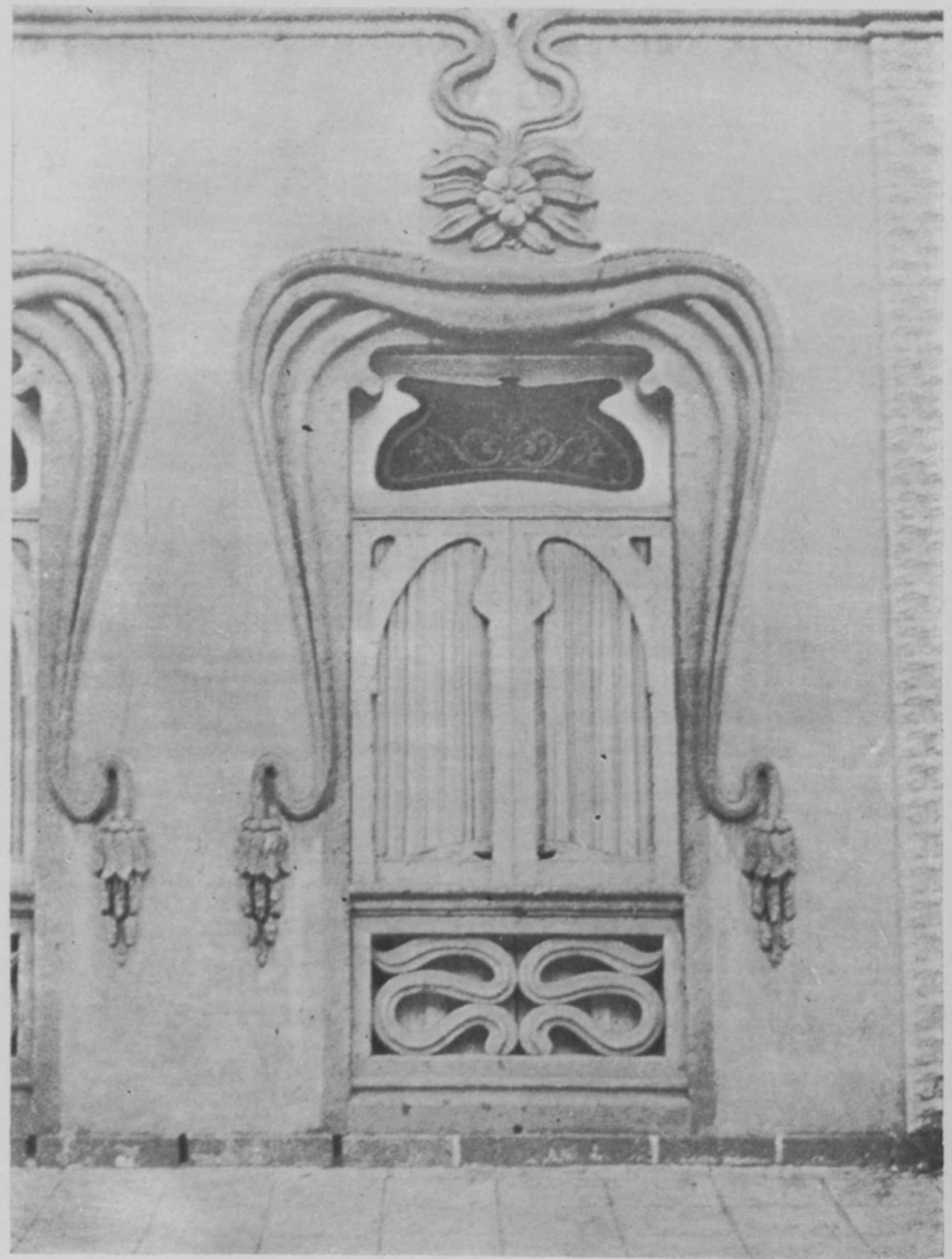

30. México. Casa en la calle de Chihuahua. Ventana. (Foto F. de la Maza.) 

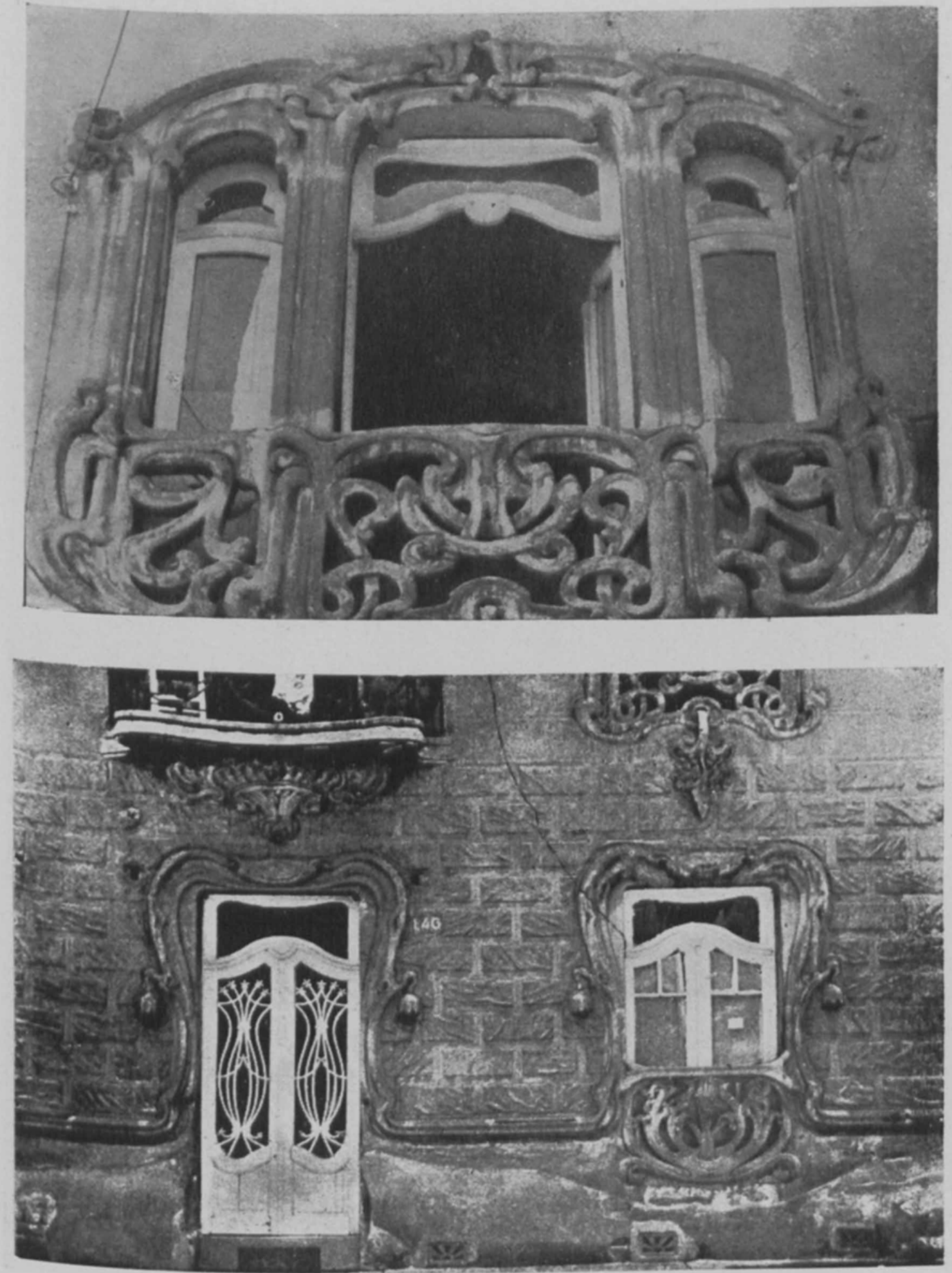

31. México. Casa en la esquina de Colima y Córdoba. Detalles. (Foto E. V. Lugo.) 
DOI: http://dx.doi.org/10.22201/iie.18703062e.1957.26.2444

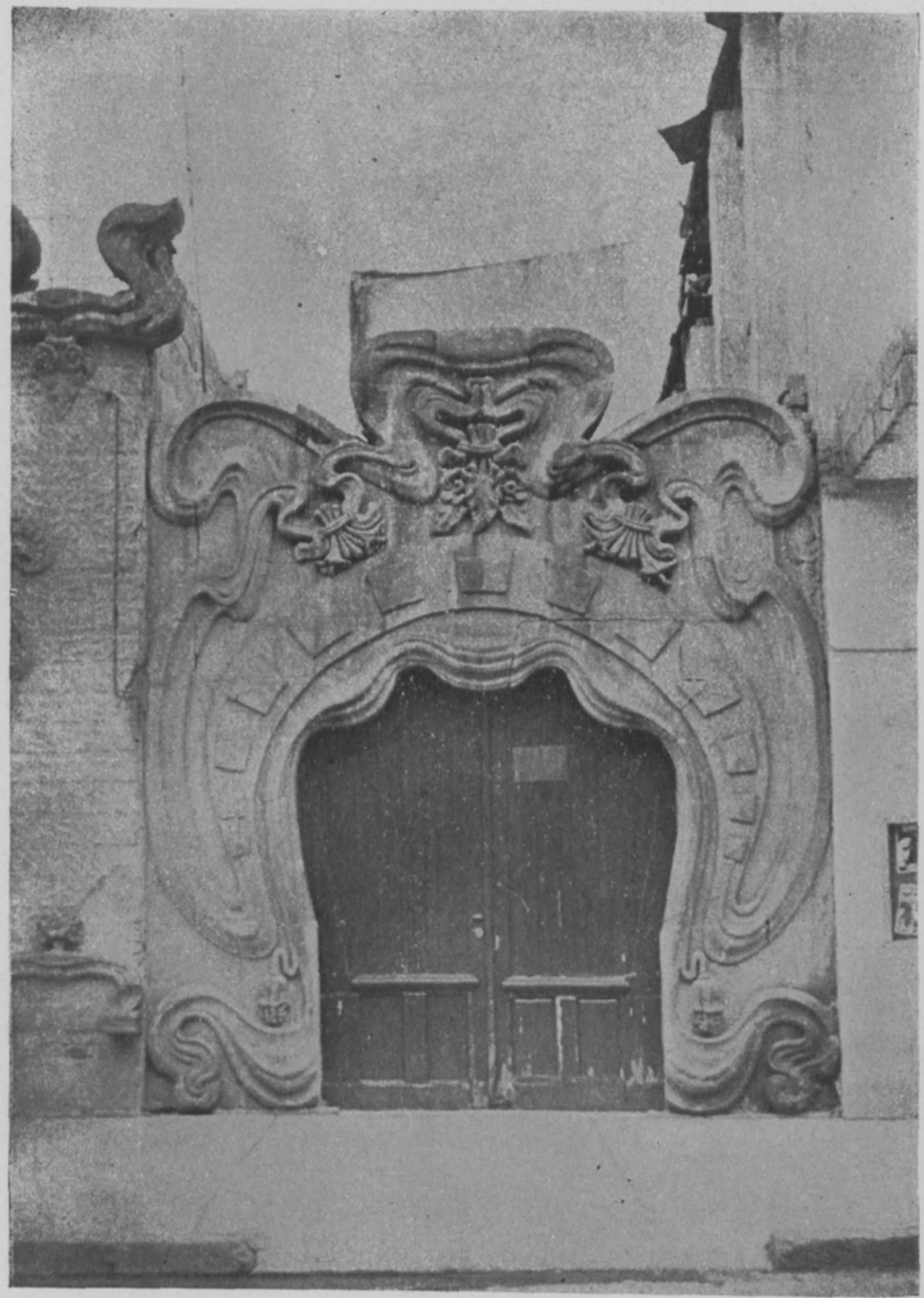

32. México. Casa en la calle de Guanajuato. Entrada. (Foto F. de la Maza.) 


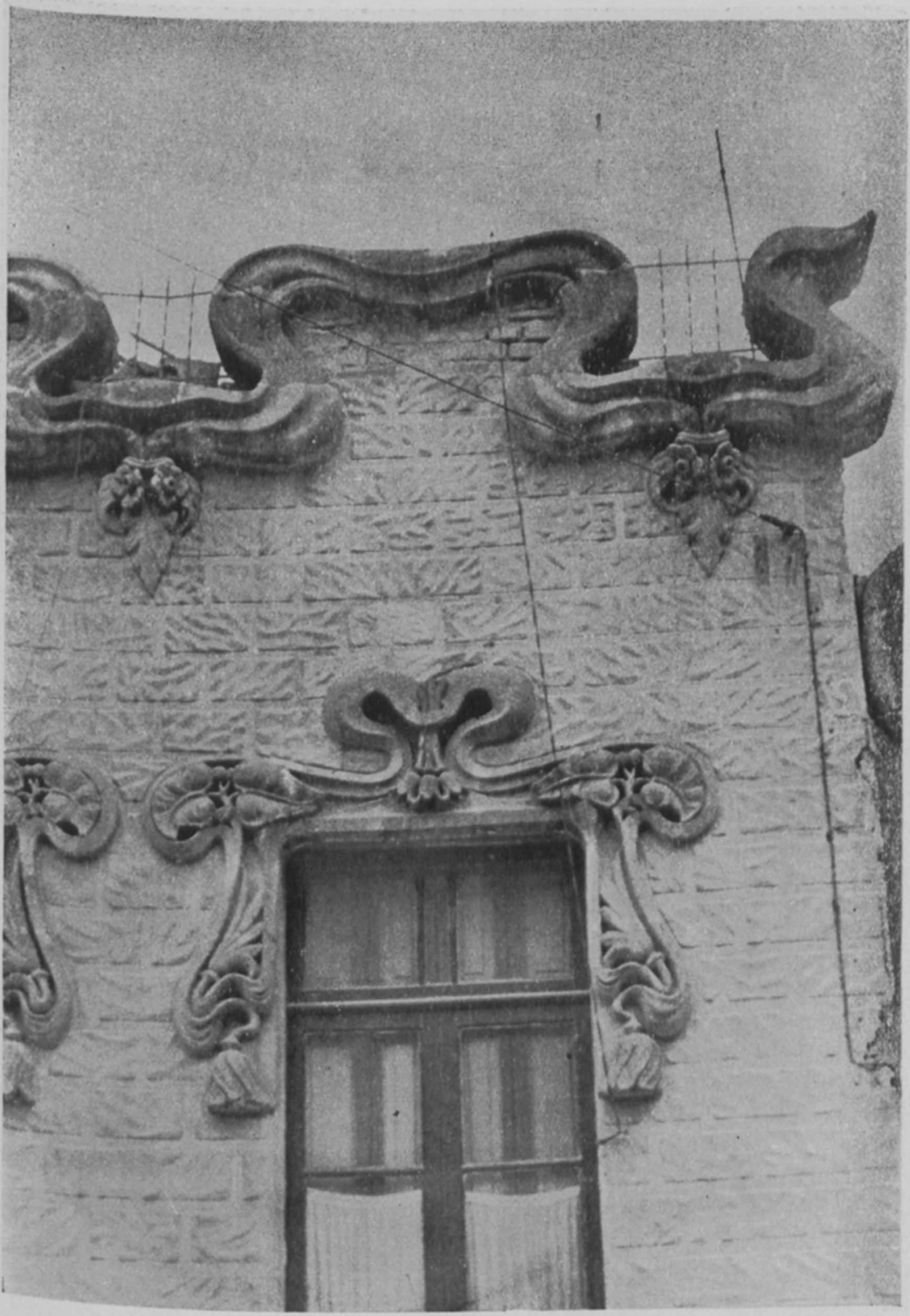

33. Detalle de la casa anterior. (Foto F. de la Maza.) 
DOI: http://dx.doi.org/10.22201/iie.18703062e.1957.26.2444

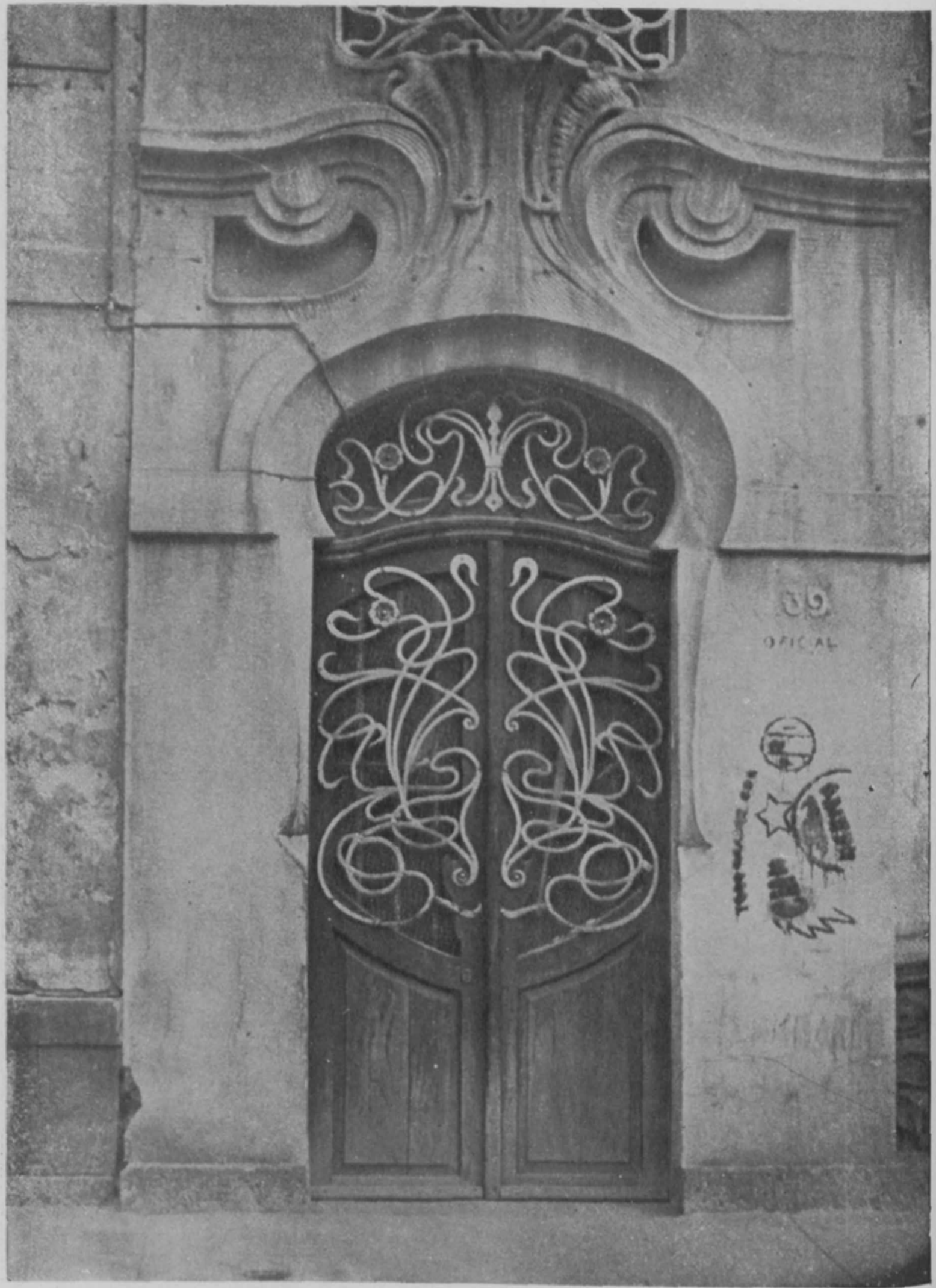

34. Casa en la calle de Prim. (Foto F. de la Maza.) 


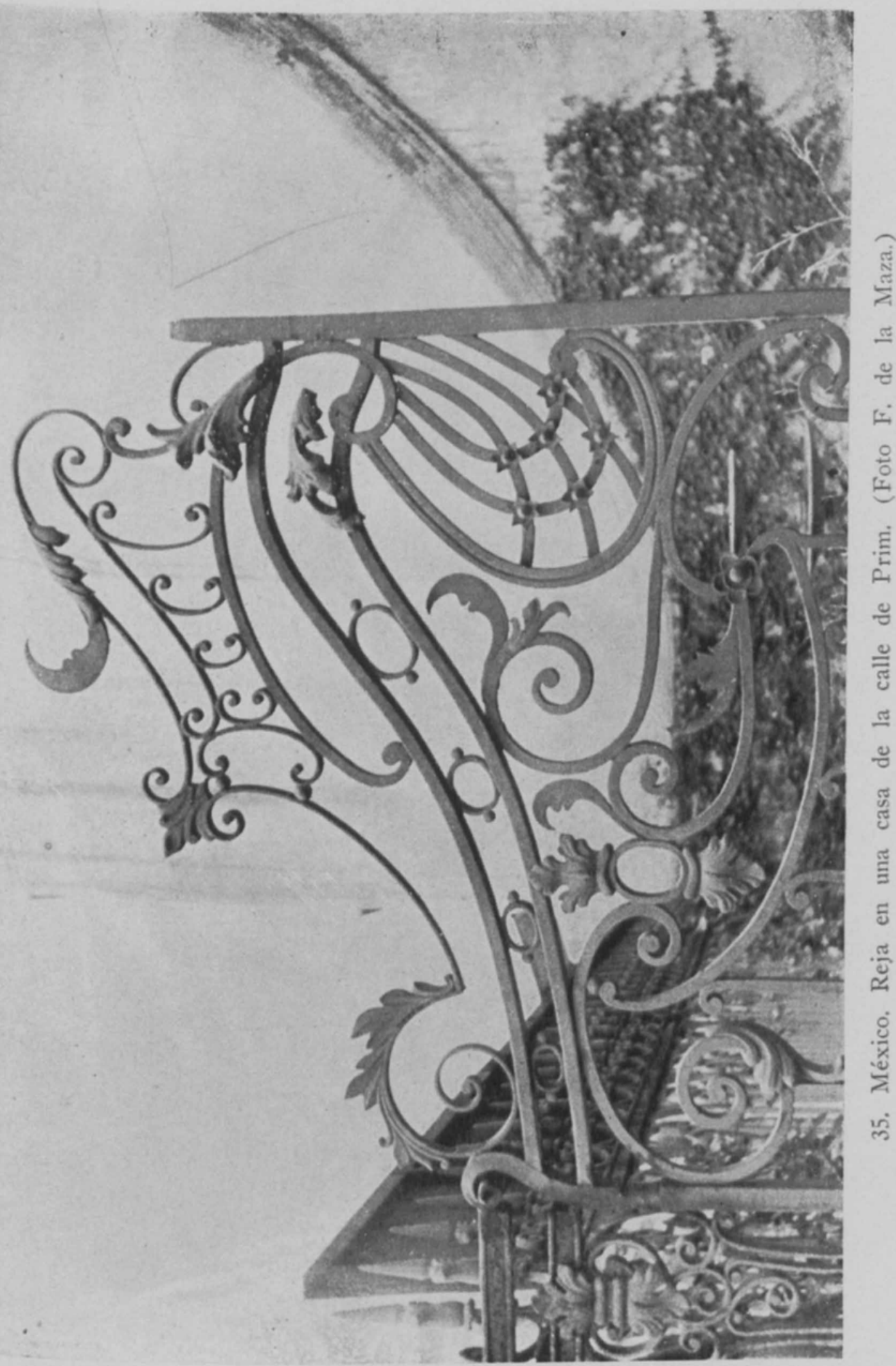


DOI: http://dx.doi.org/10.22201/iie.18703062e.1957.26.2444

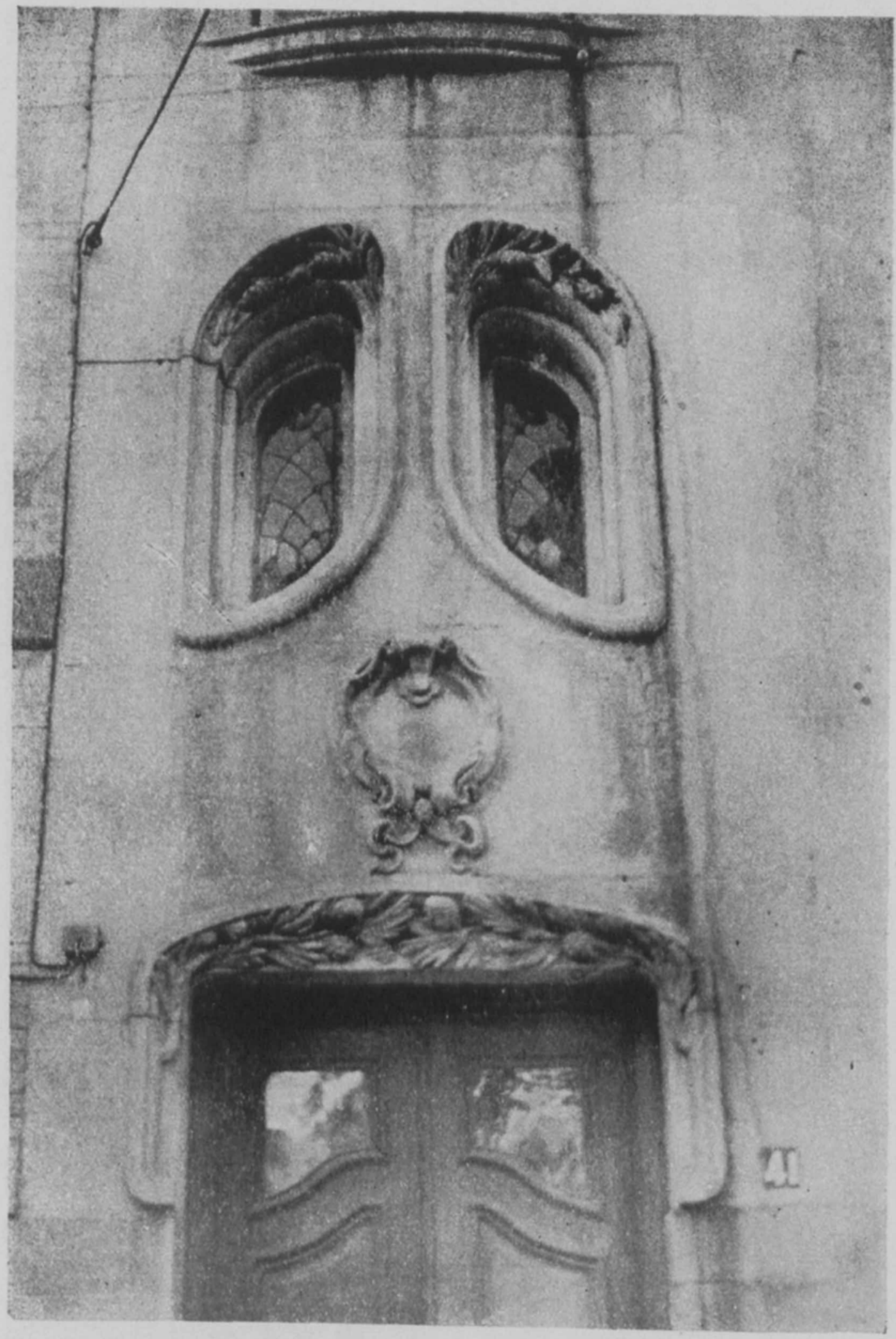

36. México. Casa en la calle de Florencia. (Foto E. Vargas Lugo.) 


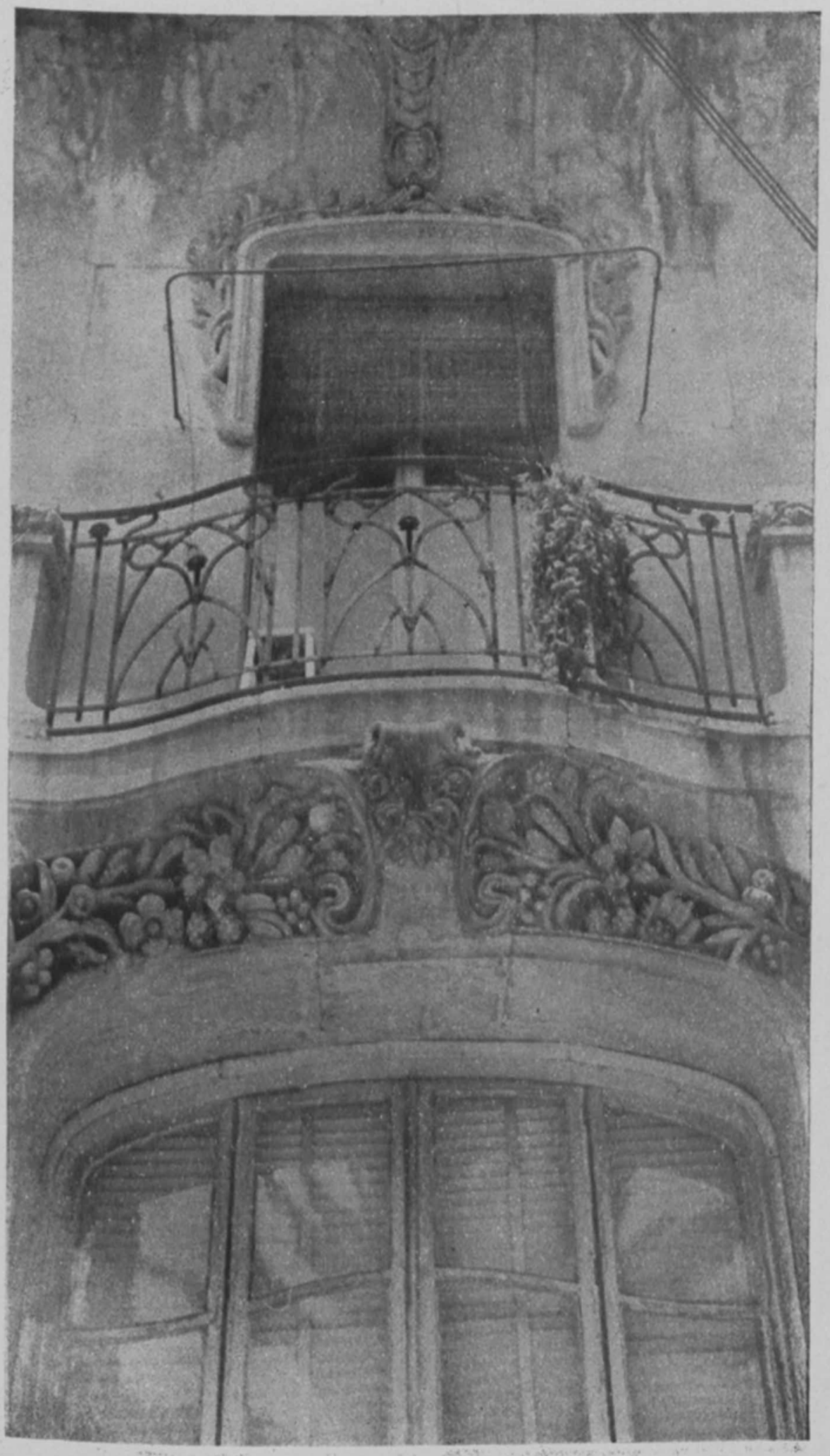

37. Balcón de la misma casa. (Foto E. Vargas Lugo.) _. . . . . ? 


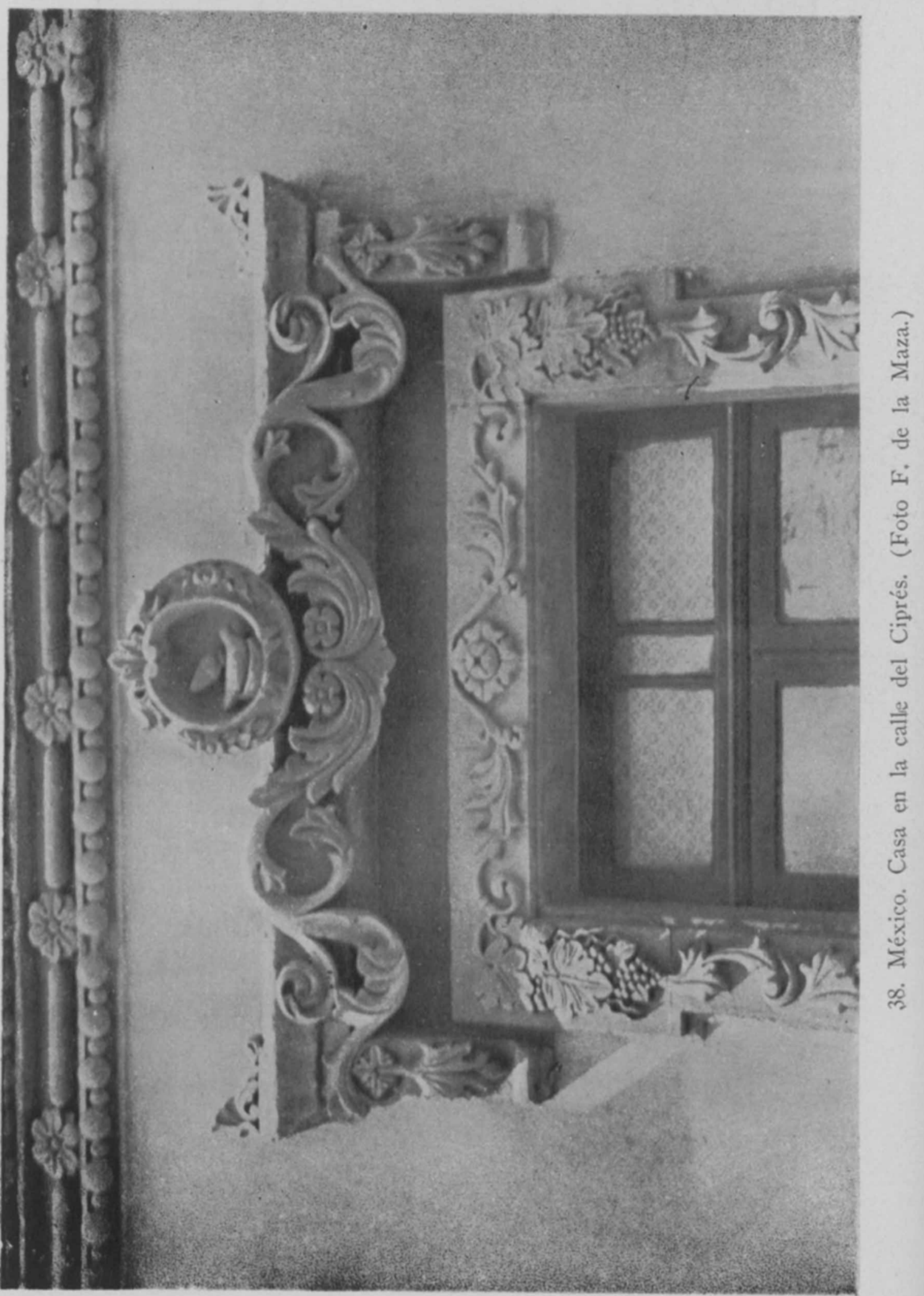


DOI: http://dx.doi.org/10.22201/iie.18703062e.1957.26.2444

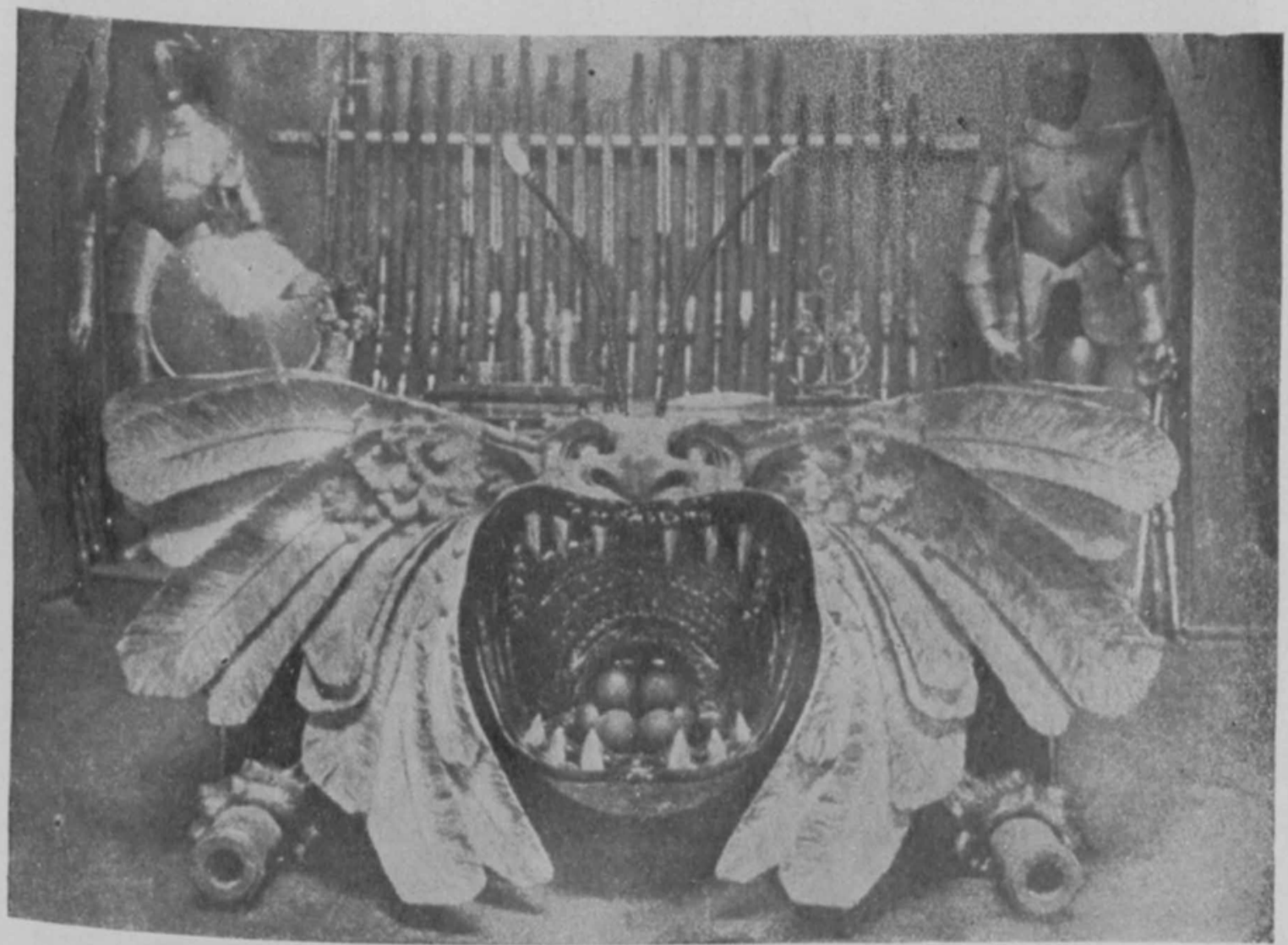

39. México. Sala de Armas de Porfirio Díaz.

(Cl. de El Mundo Ilustrado, año xIII, tomo I, $\mathrm{N}^{\circ}$ 25.) 


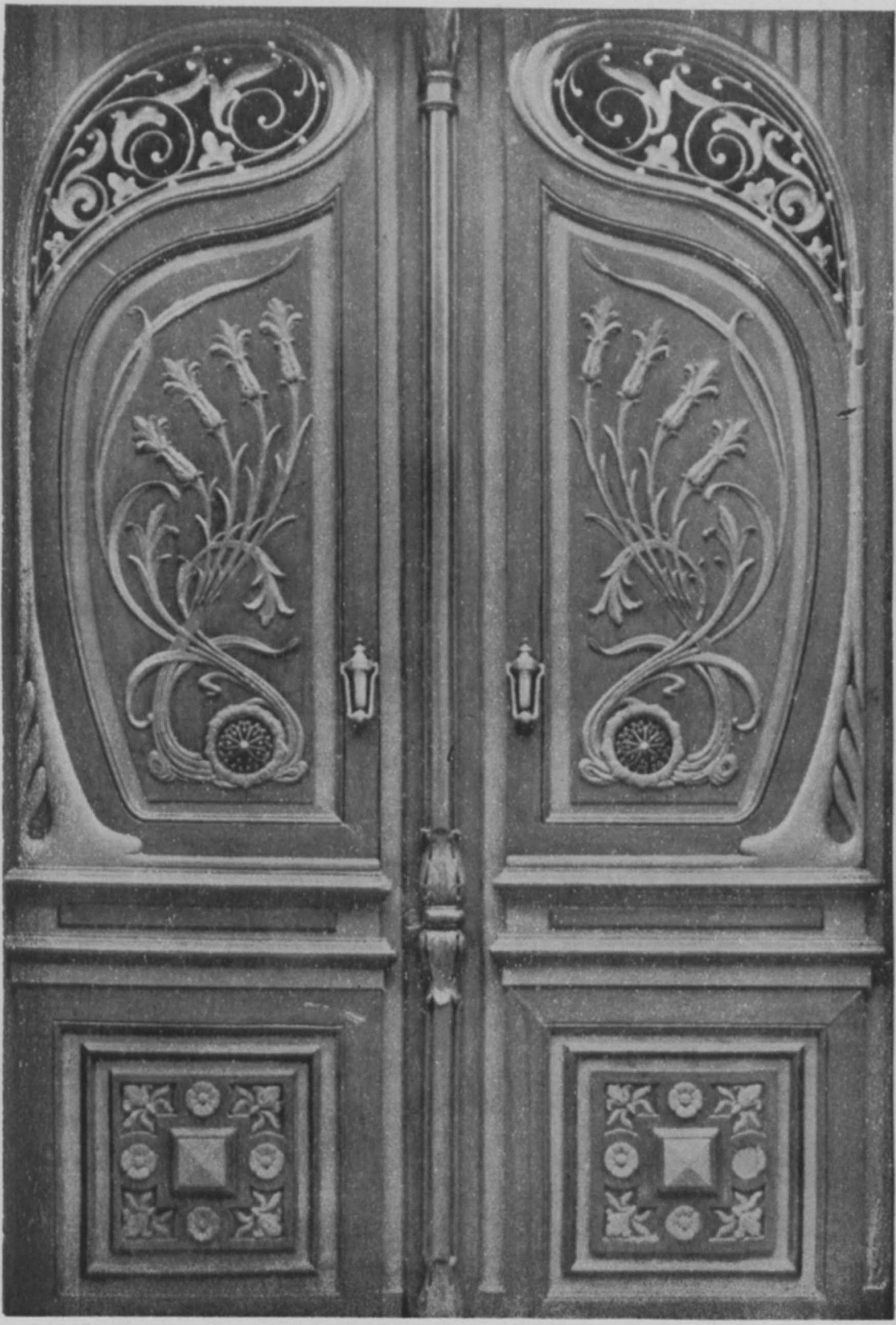

40. México. Puerta de la casa de la familia Requena.

(Foto cortesia de la Sra. Requena.) 


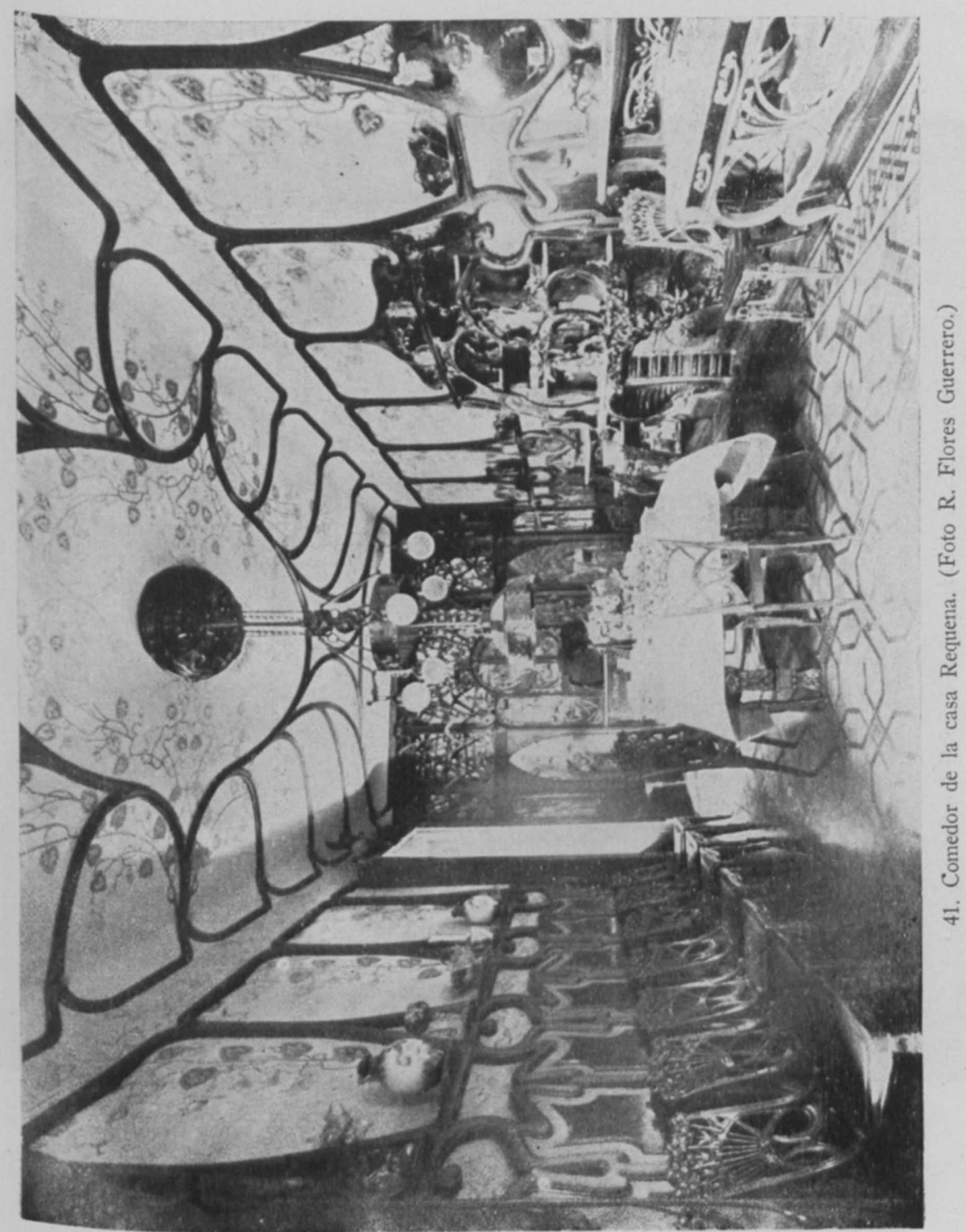




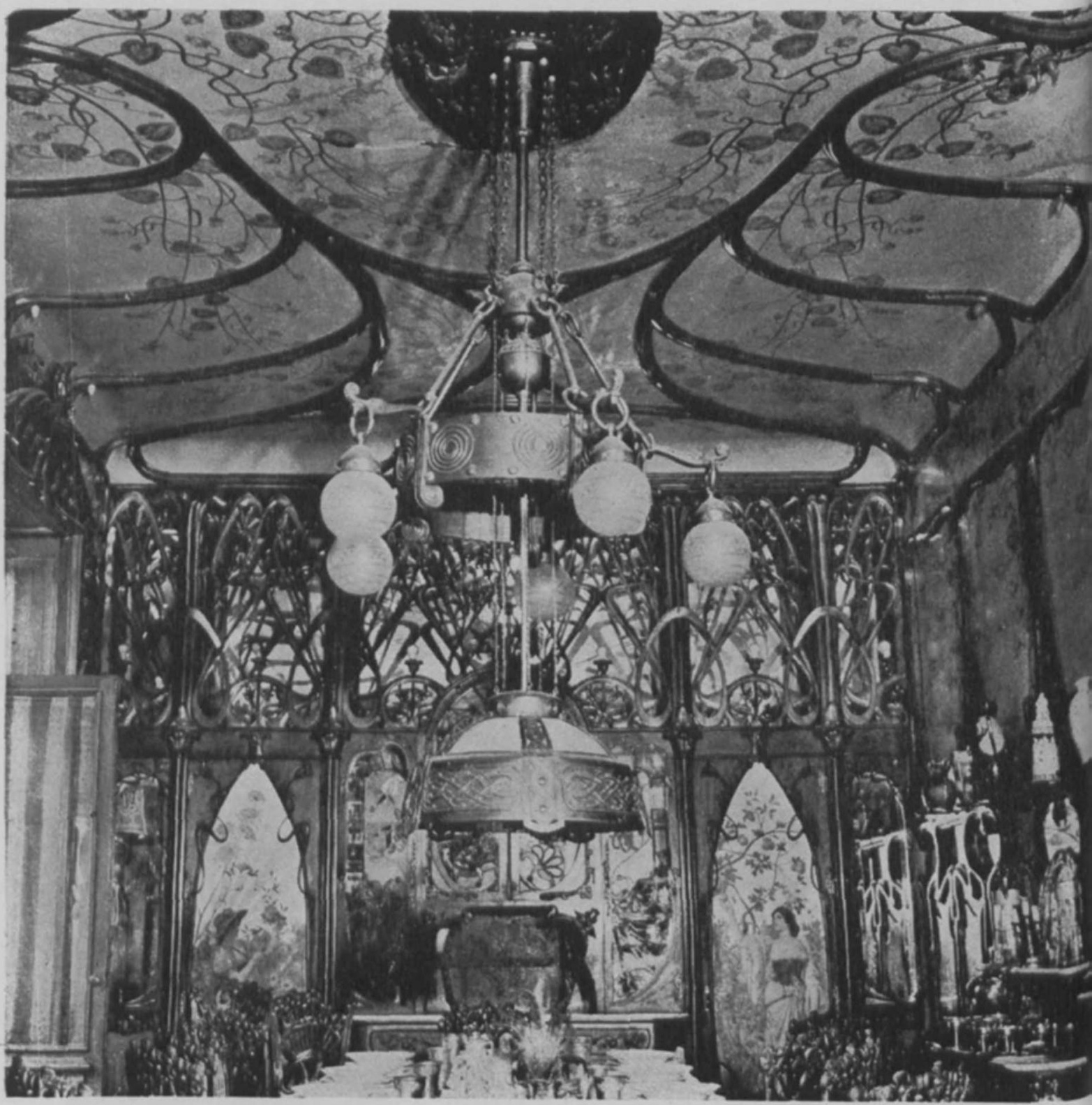

42. Detalle del anterior. (Foto R. Flores Guerrero.) 


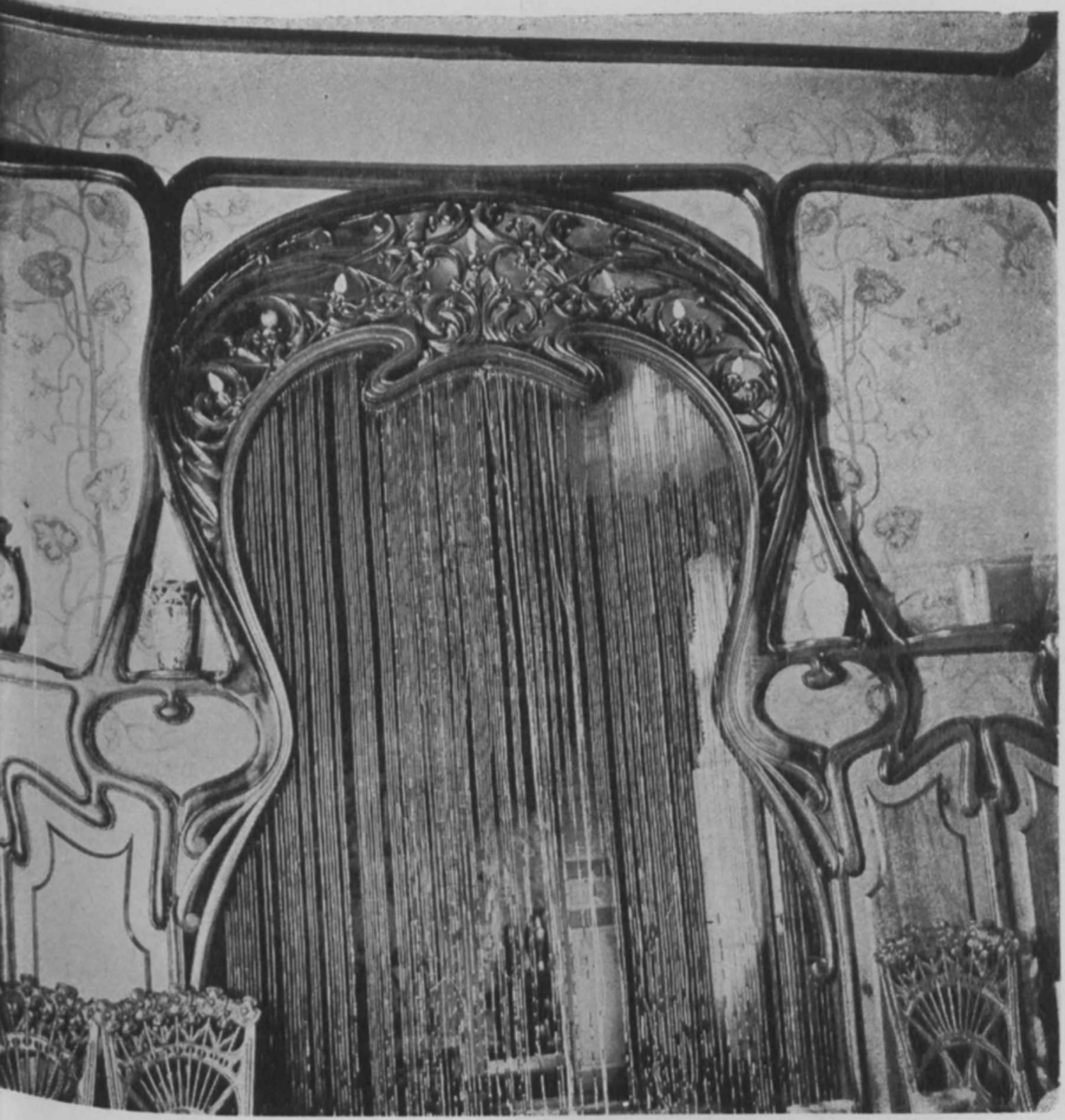

43. Casa Requena, Entrada al comedor. (Foto R. Flores Guerrero.) 

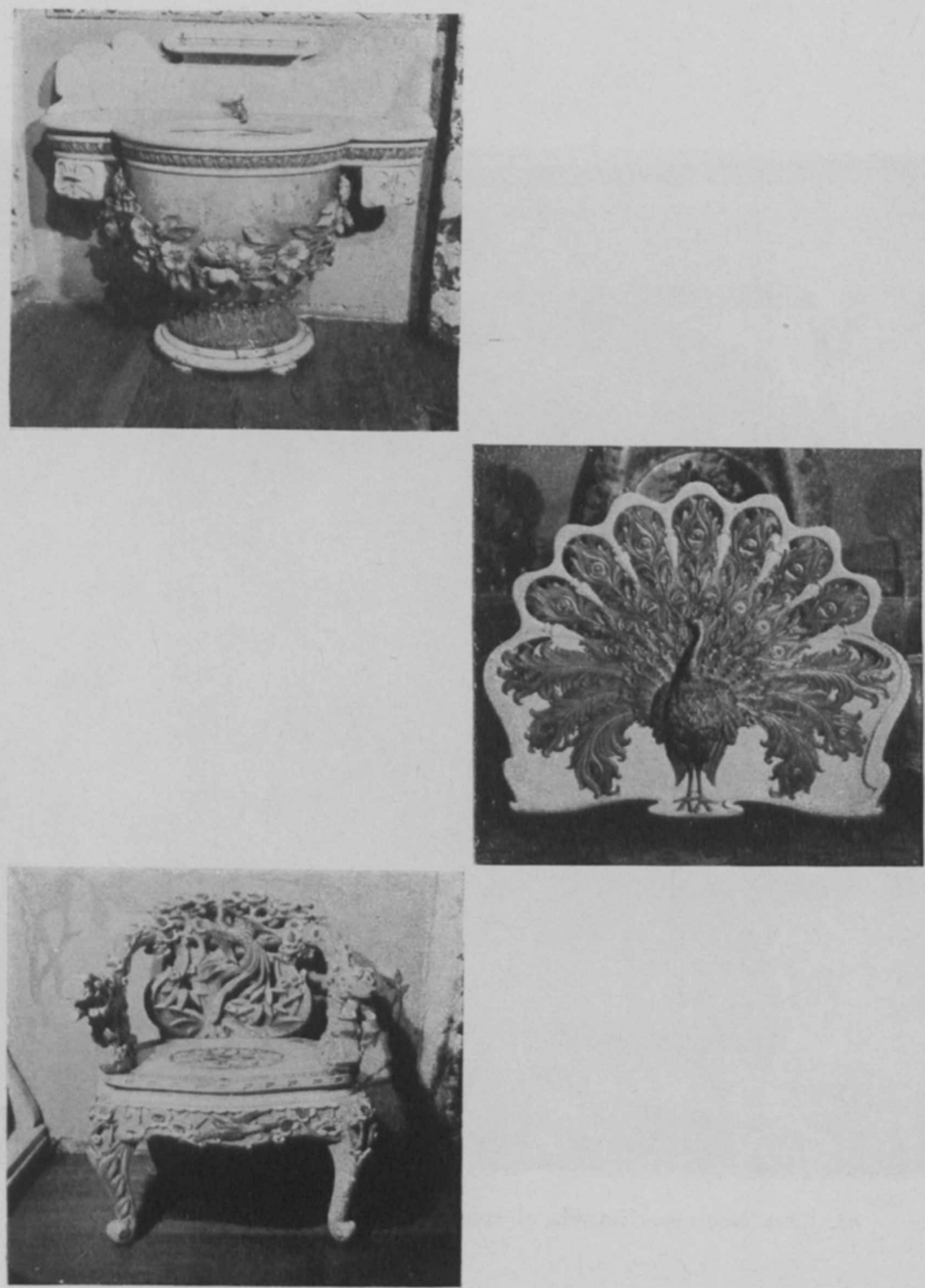

44. Lavabo, piesera de la cama y silla de la casa Requena. (Fotos R. Flores Guerrero.) 
DOI: http://dx.doi.org/10.22201/iie.18703062e.1957.26.2444

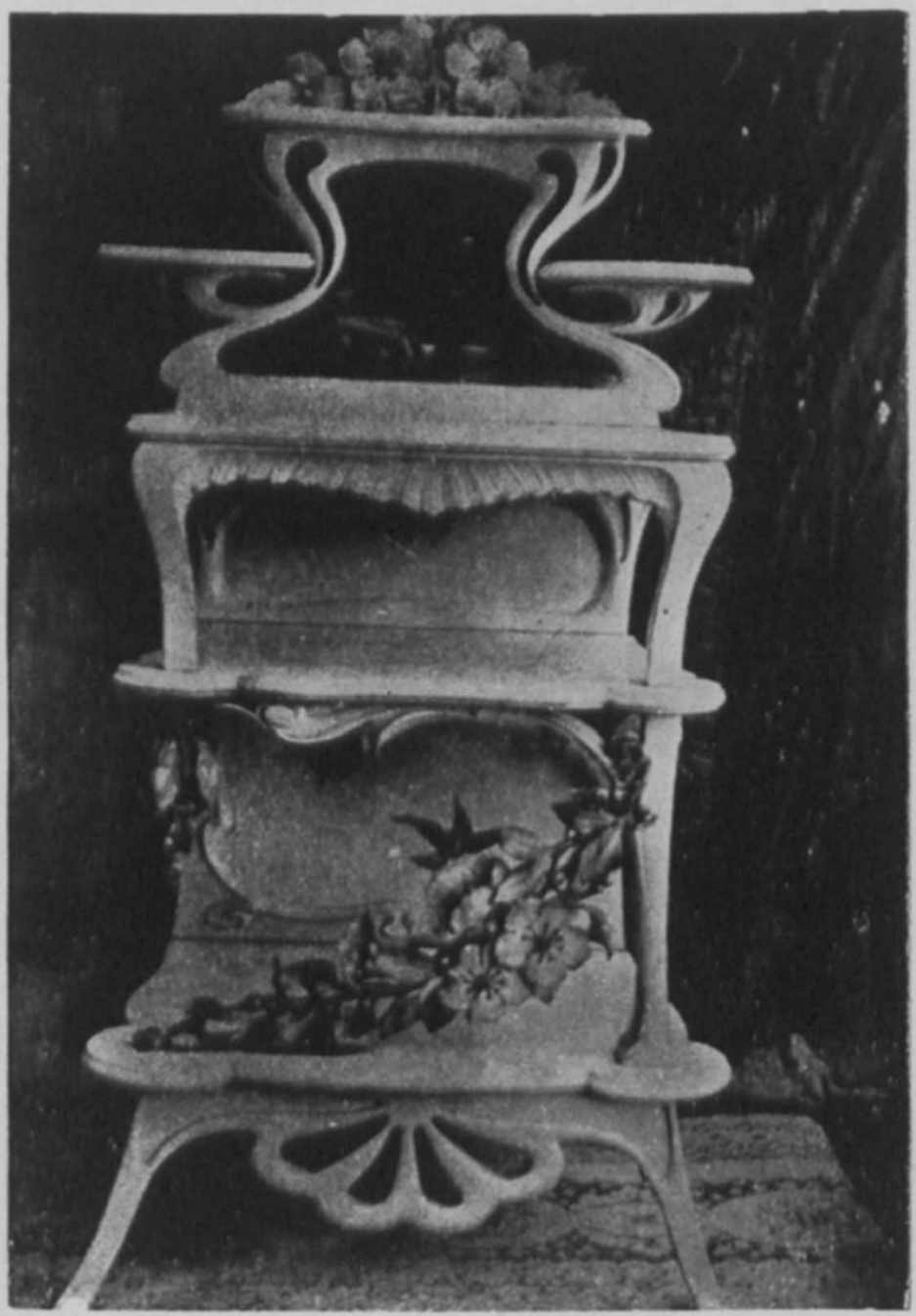

45. Mueble de la casa Requena. (Foto R. Flores Guerrero.) 


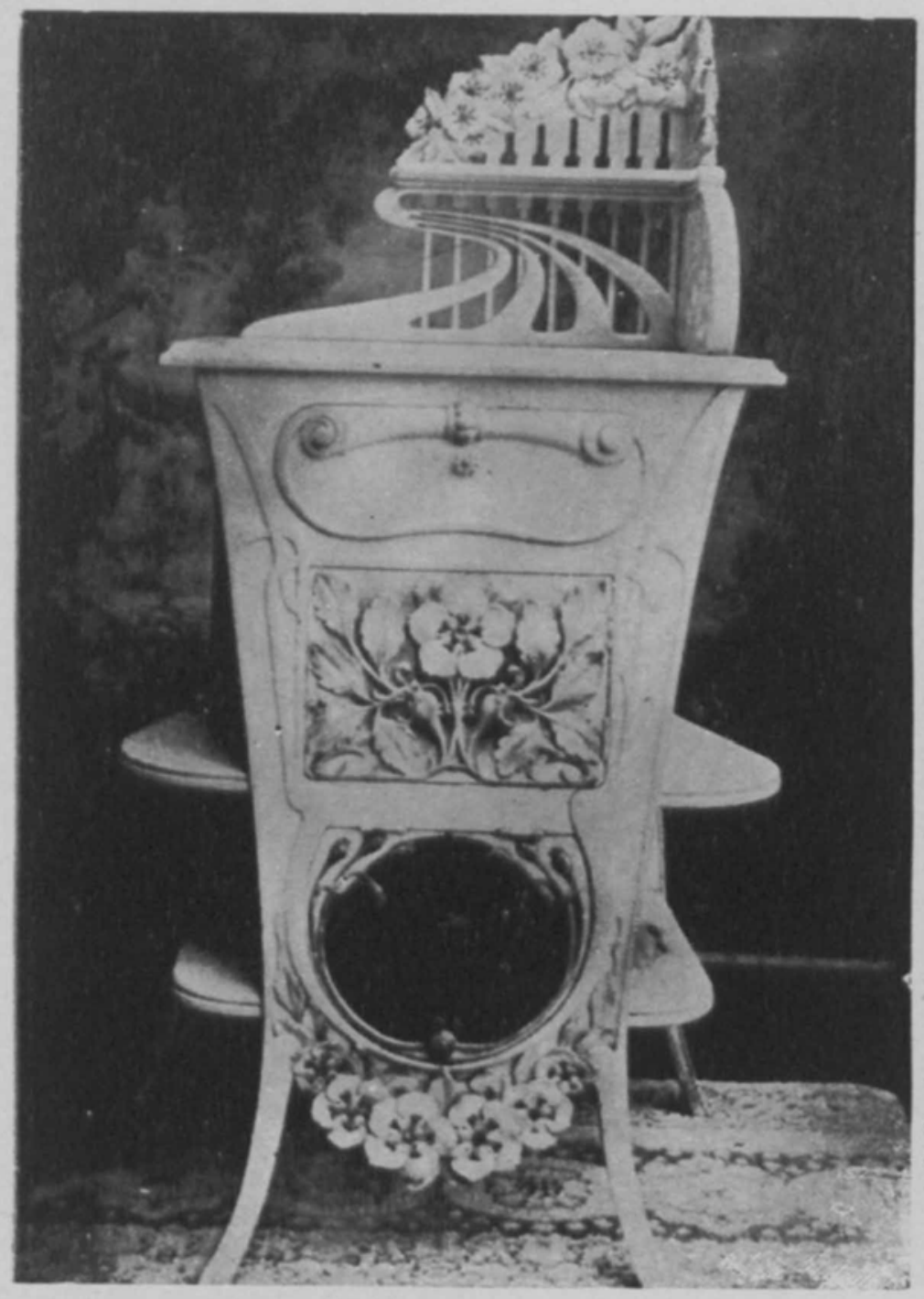

46. Mueble de la casa Requena. (Foto R. Flores Guerrero.) 


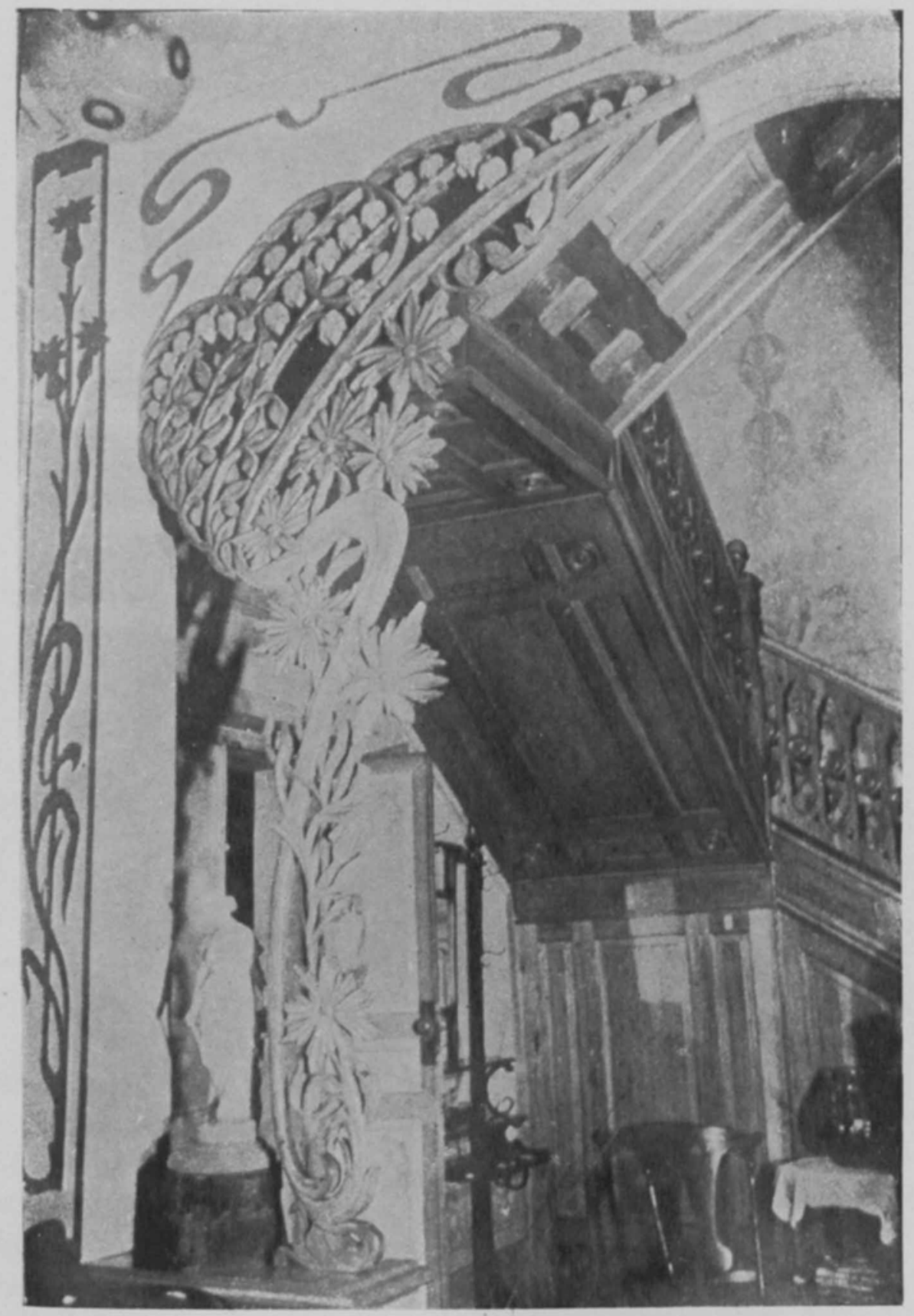

47. Detalle de un arco de madera. Interior de la casa Requena. (Foto R. Flores Guerrero.) 